\title{
Equilibrium Wage Arrears: A Theoretical and Empirical Analysis of Institutional Lock-In
}

\author{
By: John S. Earle and Klara Z. Sabirianova
}

Working Paper Number 321

October 2000 


\title{
EQUILIBRIUM WAGE ARREARS: \\ A THEORETICAL AND EMPIRICAL ANALYSIS OF INSTITUTIONAL LOCK-IN
}

\author{
John S. Earle \\ SITE, Stockholm School of Economics \\ Central European University \\ and \\ Klara Z. Sabirianova \\ Urals State University \\ University of Kentucky
}

$2000-10-20$

\begin{abstract}
We present a model of wage contract violation that implies a possibility of multiple equilibria in the level of arrears. Positive feedback arises because each employer's arrears affect the costs of late payment faced by other employers operating in the same labor market, resulting in a network externality or strategic complementarity in the adoption of the practice. We study the case of three equilibria, distinguishing two that are stable: the "punctual payment equilibrium" and the "late payment equilibrium." Our econometric analysis of linked employer-employee data for Russia supports the model's contention that the firm's costs of wage arrears - as embodied in worker effort, quit and strike behavior, and the probability of legal penalties - are attenuated by arrears in the local labor market. We estimate the arrears reaction function implied by the model, showing that it exhibits strongly positive feedback, and that the theoretical conditions for multiple equilibria under symmetric local labor market competition are satisfied in 1995 and 1998. Simulation results imply a late payment equilibrium characterized by six monthly overdue wages for a typical worker in 1995 and nine in 1998.

\section{Acknowledgements}

This research was undertaken with support from the European Union's Tacis ACE Programme and the MacArthur Foundation. We thank Andrzej Baniak, Jiahua Che, Fabrizio Coricelli, Tore Ellingsen, Guido Friebel, John Garen, Scott Gehlbach, Vladimir Gimpelson, Laurence Levin, Peter Murrell, Andrew Spicer, Valery Yakubovich, Yury Yegorov, and participants in seminars in Bonn, Seattle, and Stanford for helpful comments and discussions, and we are grateful to Paul Milgrom for a conversation that encouraged us to develop the model in this paper, while reserving to ourselves the responsibility for any errors.
\end{abstract}




\section{Introduction}

Enforceability of payment timeliness in wage contracts is both a standard feature of most employment relationships and a virtually universal assumption of economists studying labor markets. In the setting of developed market economies, the rule of wage payment in-full and on-time is proven by the rare exceptions appearing in small start-up companies facing severe liquidity-constraints, in bankrupt firms about to be shut down, or in situations of fraud. The routine practice among employers of honoring their compensation promises is presumably guaranteed both by legal institutions and by self-enforcing considerations such as the firm's interest in protecting its reputation as a reliable contractor when hiring and motivating other workers (for reasons surveyed by, e.g., Malcomson, 1997).

In post-Soviet Russia and a few other formerly socialist economies, by contrast, wage arrears have grown quickly to become large, widespread, and persistent. According to estimates from the Russian State Committee for Statistics (Goskomstat), the cumulative overdue wage debt in Russia grew from negligible level in 1991 to 77 bln rubles by the end of 1998, about 3 percent of GDP for that year. ${ }^{1} \quad$ As we show in our empirical analysis below, approximately two-thirds of Russian workers reported overdue wages in late 1998, with an average debt of 4.8 monthly salaries per affected worker. The practice of late payments has not been confined to isolated cases of start-up, bankruptcy, or fraud, but rather has been widespread in many sectors and types of firms; indeed, the incidence and magnitude of arrears appear to be greater in large firms and state-owned organizations. At the same time, they display strong regional variation, such that some regions are deeply affected and others hardly at all. ${ }^{2}$ Finally, Russian wage arrears have been far from a temporary phenomenon, instead persisting and accumulating for several years.

This paper attempts to explain the puzzle of how high and persistent wage arrears in a few economies could co-exist with only negligible, transitory arrears in most others. Our empirical work focuses on Russia, both because of data availability and because the substantial variation of arrears within Russia provides a fruitful testing ground for our theory. But our theoretical model is general,

\footnotetext{
${ }^{1}$ Figures are reported in Russian Economic Trends (1999). It should be noted that these official estimates do not cover all sectors of the economy, particularly some services, but in general the uncovered sectors are believed to have relatively low arrears.

${ }^{2}$ Desai and Idson (1998), Earle and Rose (1996), Earle and Sabirianova (1998), Gimpelson (1998), and Lehmann, Wadsworth, and Acquisti (1999) document some of the empirical patterns of Russian wage arrears.
} 
applying to wage arrears determination in other transition economies as well as providing an explanation why wage arrears are such an uncommon practice in most economies.

Our theoretical argument begins with the observation that a combination of peculiar conditions may have tended to raise the attractiveness of wage arrears in some of the transition countries, including Russia. The conditions include the general decline of output and employment in large enterprises, the broader liquidity crisis, the poor monitoring of managerial behavior, the general lack of contract enforcement, and the crowding out by government borrowing of many financial flows. ${ }^{3}$ These conditions may have increased firms' and managers' benefits in delaying wages, but we argue that they alone cannot account for the persistence of substantial arrears over several years. Even if managers would prefer not to pay their workers on time, persistence requires that workers accept late payment, at least over some time horizon, and we point to a number of factors that have limited the responsiveness of labor supply to arrears.

The key argument that we develop in this paper is that self-propagation of the wage-arrear practice may come about because a decision to pay wages late has externalities for other firms considering a late payment strategy, particularly those operating in the same local labor market. The externality arises because employees of a late-paying firm are less likely to engage in several costly actions - to quit, to reduce effort, or to strike - in response to their own arrears when other firms in the region also pay late. Legal congestion may also contribute to a positive feedback loop, as the probability of punishment may decline with the incidence of arrears in the local jurisdiction (as in Sah, 1991). In these ways, a manager's costs of using arrears are functions of the wage arrear decisions taken by other firms, and the payment practice is a strategic complement for firms operating in the same labor market.

We present this argument in the form of a model of the managerial choice of the level of wage arrears, where a critical factor in the decision is the prevalence of arrears in the firm's labor market. The model implies positive feedback from the wage arrear practices of other firms through the several ways in which they influence costs, and under some specific conditions it generates multiple equilibria in the level of wage arrears. For a particular functional form of the manager's net benefits from arrears, we calculate a possible set of three symmetric Nash equilibria: a stable "punctual payment equilibrium," an unstable "critical mass equilibrium," and a stable "late payment equilibrium." The stable equilibria can

\footnotetext{
${ }^{3}$ Some of these conditions, particularly the first two, are discussed in other studies of Russian arrears and labor markets, including Layard and Richter (1995) in addition to those cited in the previous footnote.
} 
be interpreted as reflecting institutional lock-in, in the case of the late payment equilibrium implying that massive coordination may be required to move the economy back to the institution of punctual payment. ${ }^{4}$

The model explains not only why arrears may tend to persist, but also some other empirical regularities of arrears: the strong regional variation and the tendency for arrears to be greater in older and larger employers. Although focussing attention on the interaction effects among employers in spurring and sustaining arrears, the model also permits roles for other factors that may have affected firm and worker behavior, as outlined above, and thus it suggests important variables that should be controlled for in the empirical analysis.

Motivated by the model's implication that both worker and firm characteristics are relevant to the determination of wage arrears, our empirical work analyzes a linked employee-employer panel database. The data are drawn from a national probability sample of employees and industrial firms all over Russia, including surveys we have carried out for this purpose, and they contain rich information on both sides of the labor market from 1994 to 1998 . In addition to documenting some of the key regularities of wage arrears, the analysis contains three parts: first, an empirical examination of some of the assumptions of the model, involving restrictions we place on some elements of the wage arrears cost function implying strategic complementarity; second, an explicit test of the principal hypothesis of the model - positive feedback in the firm's reaction function - as well as its higher-order shape; and third, a simulation of the set of symmetric Nash equilibria implied by the empirical estimates of the theoretical model.

We show that the data support the model's assumptions on the cost function, in particular the attenuating effect of local labor market arrears on workers' quit, effort, and strike responses to their own arrears and on the probability of legal penalties. Our empirical estimates of the reaction function display strong positive feedback and a shape implying the possibility of multiple equilibria in two years of our sample: 1995 and 1998. Assuming symmetric competition in the local labor market and Nash behavior by managers, we calculate the three equilibria implied by our empirical estimates.

The analysis in this paper contributes to several distinct strands of economic research. To start with, recent research on the historical foundations of successful modern economies has emphasized the importance of contract enforcement institutions and property rights (Greif, 1993; Greif, Milgrom, and Weingast, 1994; Milgrom, North, and Weingast, 1990; North, 1990). While providing explanations for

\footnotetext{
${ }^{4}$ Our use of the term "institution" as the set of equilibrium strategies in a game is consistent with Aoki's (2000) "third view" of the definition of an institution.
} 
the function and origins of such institutions as the merchant guild and the law merchant, the literature has paid less attention to institutional arrangements when contracts are not enforced nor to the mechanisms that may lead such arrangements, even if inferior, to be self-sustaining. A second strand of literature concerns coordination failures, particularly in developing economies, where the possibility of an "underdevelopment trap" due to investment spillovers has been studied by Rosenstein-Rodan (1943) and Murphy, Shleifer, and Vishny (1989), and extended to issues such as human capital investment (Azariadis and Drazen, 1990) and training (Acemoglu, 1997); Hoff (2000) contains an overview of this work.

More generally, the notion that spillovers create positive feedback and possibly multiple equilibria in outcomes appears to have explanatory power in a number of fields. For instance, externalities may help to explain persistent regional variation in crime rates, whether due to legal congestion (Sah, 1991) or social interactions and learning (Glaeser, Sacerdote and Scheinkman, 1996). Informational cascades, arising where others' actions but not their signals are observable, may account for a variety of types of behavioral convergence (Bikchandani, Hirshleifer and Welch, 1998). The desire to conform because of some punishment on nonconformity or preference for similarity may account for the existence of clusters of customs and conventions (Akerlof, 1980; or Young, 1993), explaining phenomena as varied as rules of the road (Young, 1996) and social norms in the welfare state (Lindbeck, Nyberg, and Weibull, 1999). Network externalities may create multiple equilibria and path dependence in technology adoption (David, 1985; Katz and Shapiro, 1986; Arthur, 1989). Spillovers in investment, market participation, or technology may produce the possibility of multiple levels of equilibrium aggregate output and employment (Cooper and John, 1988; Kiyotaki, 1988), providing an alternative explanation for business cycles as "regime switches" (Chamley, 1999). Some efficiency wage models (e.g., Stiglitz, 1985) also rely on an externality generated for other firms when an employer chooses to pay a wage premium either to lower quits or to increase effort, and it has been argued that employers' layoff and training decisions contain similar externalities as well (Levine and Parkin, 1994). The general class of games with strategic complementarities has been extensively analyzed by Milgrom and Roberts (1990), among others. Relatedly, sociologists have spent much effort investigating collective behavior and "institutional isomorphisms" in a variety of fields (e.g., Granovetter, 1978; DiMaggio and Powell, 1983; Fligstein, 1985). 
In all of these examples, a broadly similar interaction mechanism works to promote convergent practices, and, depending on parameters, the positive feedback may generate multiple equilibria. Most of the research has been purely theoretical, however, and empirical analyses of the phenomena are comparatively undeveloped, perhaps because appropriate data are frequently not available and because testing has been hampered by the difficulty of observing the interaction and feedback processes directly. In the absence of such observations, evidence on the strength of the interaction effect must rest on the possibility of disentangling it from the impact of unobserved heterogeneity, as in the decomposition of regional variation in crime rates by Glaeser, Sacerdote and Scheinkman (1996). With respect to wage arrears, our argument in this paper is that analysis of interaction in the local labor market is critical for understanding their persistence, and we are able to measure many of the relevant characteristics of the local labor market environment, of firms and of workers using our linked data across regions. Moreover, we are able to estimate individual firm reaction functions and to measure several mechanisms - based on the quit, effort, and strike behavior of employees and on the functioning of the legal system - that we argue provide feedback loops that may generate multiple equilibria in the degree of late payment.

Finally, the paper contributes to the literature on the role of institutional change in economic development and in the transition from a socialist system to a market economy. One strand of research on transition economies has focussed on the inertia in some types of economic behavior, that is the tendency for routines to continue to be followed even when they may be dysfunctional in the new environment (Murrell, 1992), while a major theme in the literature is the importance of new institutions that should be created for markets to function well (e.g., Dewatripont and Roland, 1996; Greif and Kandel, 1995). But there is a comparative dearth of detailed empirical work examining the actual practices epprging in the transition economies, with the partial exception of studies of corporate governance. $^{5}$ Furthermore, there has been rather little attention to the possibility that some recently evolved institutions may actually serve to undermine the functioning of markets. ${ }^{6}$ Although a complete welfare analysis is beyond the scope of the paper, we argue that pervasive, institutionalized wage arrear practices represent contractual failure on a large scale and have perverse consequences for the more

\footnotetext{
${ }^{5}$ But see McMillan and Woodruff (1999) and Hendley et al (1997) for detailed empirical studies of informal credit in Vietnam and of legality in Russia, respectively.

${ }^{6}$ Gaddy and Ickes (1998) discuss the role of barter deals in reducing incentives for restructuring in Russia's "virtual economy," and Frye and Shleifer (1997) analyze the impact of local government policies on small business operation in Poland and Russia.
} 
general development of enforceable contracts and secure property rights, arguably among the most important institutions of a market economy (North, 1990).

\section{A Model of Equilibrium Wage Arrears}

In this section, we present a highly stylized model of managerial decisions concerning wage arrears. The model is designed to focus attention on the possibility of positive feedback through the influence of wage arrears in the employer's labor market (taken in the empirical work to be the local labor market) on the costs of using the practice. Because we would like to test several of the model's assumptions and implications, however, it also includes a number of other factors that are important to control for and that we test as well. Although arrears decisions have an important dynamic component, including the expectations of managers and workers concerning each other's behavior and the evolution of exogenops determinants, our static model captures the essential features of arrears that we would like to describe. ${ }^{7}$

We begin by laying out the model's assumptions, then we solve it and present comparative static results including the shape of the best-response function of a manager to the local labor market environment. Assuming symmetry in the local labor market (identical reaction functions across firms), we solve for the Nash equilibria and show the conditions under which multiple solutions exist. We demonstrate the model's properties taking as an example a particular functional form, which we also use as the basis for estimation in the next section. The final part of this section summarizes the model's testable assumptions and implications, which we investigate empirically in Section 3. Discussions of issues outside the model, including equilibrium selection, robustness and welfare, are postponed until the concluding Section 4 of the paper.

\subsection{Assumptions}

Consider a firm with a single manager whomaximizes his/her private net benefits by choosing the level of back wages owed a particular employee. ${ }^{8}$ This level, $\omega$, can be thought of as a loan from the worker to the firm, and we assume it earns the manager a gross return of net present value $R$ with marginal return $R_{\omega}(X)=r(X)$ assumed to be constant in $\omega$ but varying according to some characteristics

\footnotetext{
${ }^{7}$ In addition, it is problematic to estimate a dynamic model due to the shortness of the time series available.

${ }^{8}$ The model would be little affected were we to assume profit maximization instead, but our assumption of managerial utility maximization is less restrictive, and we are uncomfortable with characterizing Russian firms, in particular, as profit maximizers.
} 
of the firm, $X$. The relevant characteristics may include the liquidity needs of the firm, the effective interest rate that it faces in borrowing from other sources, and the ability of the manager to appropriate the returns by diverting the funds to projects earning private benefits. In Russia until the August 1998 crash, for example, poorly monitored managers could invest spare funds in short-term Government Treasury bills ("GKOs"), earning rates up to 150 percent. In this situation, wage arrears are likely to be more attractive to managers who can relatively easily and secretly channel the extra cash flow to their own purposes.

While it is not difficult to appreciate the potential benefits that might be obtained from postponing wage payments, the manager naturally faces costs of wage arrears as well. The model permits worker response to arrears leading to four types of costs: lowered worker effort, and increased turnover, strikes, and lawsuits. ${ }^{9}$ Our argument with respect to each of these is that the associated costs are positive functions of $\omega$, but that this positive relationship is attenuated by the magnitude of arrears in the rest of the firm's local labor market, $\Omega$. The rationale for each type of cost is fairly straightforward, and we provide evidence on the model's assumptions about the forms of these costs in the empirical analysis below.

A first cost arises because delaying wages is likely to reduce worker morale, and if effort is not perfectly observable then workers may be more likely to shirk or even, in extreme cases, to sabotage the firm. Where workers have some discretion over their hours of work, they may reduce the amount of time on the job. We do not model this agency problem, but instead assume that the manager expects that higher arrears raise effort costs, $E$, by reducing the worker's effort and productivity through mechanisms similar to those discussed in the efficiency wage literature (Akerlof, 1982; Shapiro and Stiglitz, 1984). Such costs are likely to be greater for some types of workers than for others; we parameterize this heterogeneity as a set of worker characteristics, $Z^{E}$, which could include factors such as the importance of morale for productivity, the difficulty of monitoring, and the degree of independence the worker has in decision-making. We hypothesize that the negative effort effect is attenuated by the level of wage arrears in the rest of the firm's local labor market, $\Omega$, as workers' effort decisions are influenced by their outside alternatives (for instance, if they are caught shirking and fired) and perhaps by their perceptions

\footnotetext{
${ }^{9}$ Although we do not assume profit maximization, these costs to the firm reduce the rents that the manager can take out of the firm, implying that they should matter to the manager as well.
} 
of the practice's fairness or legitimacy. The effort costs may thus be written as $E\left(\omega, \Omega, Z^{E}\right)$, with $E_{\omega}>0$, $E_{\Omega}<0$, and $E_{\omega \Omega}<0$.

Arrears may also increasequits, if the worker responds by leaving for other employments or exiting the labor force altogether. ${ }^{10}$ Quits impose costs $Q$ of replacement, associated with the need for hiring, screening, and training new employees (as in, e.g., Oi, 1962; or Stiglitz, 1974). Again, the quit decision is not modeled explicitly, but we assume that the manager knows the probability of the worker quitting as a function of $\omega$ and $\Omega$; here, we hypothesize a negative impact of the wage arrears environment $\Omega$ on quits, on the worker's quit response to arrears and thus on the firm's marginal cost of arrears. $\Omega$ is argued to affect the quit responsiveness to $\omega$ negatively because it reduces the attractiveness of mobility to other firms. Because workers differ in their mobility costs and outside opportunities, we permit the quit function to vary with a set of characteristics such as firm-specificity of skills, mobility costs, local labor market conditions, etc, included in the $Z^{Q}$ vector, so that $Q\left(\omega, \Omega, Z^{Q}\right)$, with $Q_{\omega}>0, Q_{\Omega}<0$, and $Q_{\omega \Omega}<0$.

Arrears may increase strikes and other forms of protest behavior, resulting in costs summarized by $S\left(\omega, \Omega, Z^{S}\right)$. Again, we assume a positive relationship that is attenuated by arrears in the local labor market, such that $S_{\omega}>0, S_{\Omega}<0$, and $S_{\omega \Omega}<0$. The argument here is that, similar to bargaining patterns frequently observed in unionized firms in market economies, workers view their own arrears in the context of what is "normal" in their environment, and they are less likely to protest their firm paying them late when their friends and neighbors are also being paid late by their employers. The probability of such behavior is likely to be a function of other characteristics of the firm and worker, particularly the extent of unionization, included in a set of exogenous variables $Z^{S} .11$

Finally, wage arrears are violations of legal contracts, resulting in possible legal penalties and associated costs $L\left(\omega, \Omega, Z^{L}\right){ }^{12}$ Again, we hypothesize that the probability of these events is positively

\footnotetext{
${ }^{10}$ Earle and Sabirianova (1998) point out that quitting workers may be less able to enforce back wage payments, which creates a bonding effect that may reduce the propensity of workers to quit in response to arrears. Our model assumes only that quits are costly on the margin, and it permits the quit response to vary with $\Omega$, while our empirical work includes estimates of the relationship.

${ }^{11}$ Our choice of these variables and our analysis of Russian strike behavior more generally are motivated by the broader literature on strikes; see, e.g., Kennan (1986). Our hypothesis that strike behavior in response to arrears is partially a function of arrears in the local labor market is related to the standard notion that employees may guage their wage and benefit demands to those in some reference firm or sector, as in "pattern bargaining" and use of "pay comparabilities;" see Levinson (1960) for an early discussion, and Lee and Pesaran (1993) for a more recent empirical analysis.

${ }^{12}$ The Russian Labor Code explicitly requires on-time payment of wages, and firms may be called to account either by the civil courts (when workers file a lawsuit) or the Ministry of Labor's Inspection Service. The latter has been known to fine managers as well as firms, and, more rarely, to order managerial dismissal.
} 
related to the level of arrears in the firm, but that the strength of the relationship is lower in jurisdictions with higher arrears. Our main argument is that the legal system in a region may become congested with arrears cases, reducing the probability of punishment, similar to Sah's (1991) analysis of the probability of punishment falling with the incidence of crime. An additional factor could be a reduced tendency for workers to file lawsuits in an environment of high arrears, both because they would be more likely to perceive arrears as normal and legitimate and because they may be more pessimistic about the chances of resolving the problem through legal channels. When analyzing the impact of local labor market arrears on the relationship between legal penalties and wage arrears of a firm, it is also important to take into account regional variation in the effectiveness of the legal system stemming from factors other than the congestion and lawsuit filing effects, $Z^{L}{ }^{13}$

To summarize, managers face four costs of wage arrears: $E, Q, S$, and $L$, each of which is a function of $\omega, \Omega$, and some shift variables, the vector $Z$. Although the costs are not directly observable, some proxies for the underlying behavior can be measured, which we exploit in our empirical work. For convenience in the exposition of the rest of the model, we consider the sum of the four costs $C(\omega, \Omega, Z)$ $=E\left(\omega, \Omega, Z^{E}\right)+Q\left(\omega, \Omega, Z^{Q}\right)+S\left(\omega, \Omega, Z^{S}\right)+L\left(\omega, \Omega, Z^{L}\right)$, where $Z=\left(Z^{E}, Z^{Q}, Z^{S}, Z^{L}\right)$. Thus, we assume that the manager chooses $\omega$ to maximize the expected net return to wage arrears:

$$
\max _{\omega} \pi=R(\omega, X)-C(\omega, \Omega, Z)
$$

where $\omega$ is the amount of back wages owed the worker and $\Omega$ is the average amount of wage arrears in the local labor market outside the firm. $\pi$ is the manager's private net return; clearly some benefits and costs of the practice accrue to the firm, and the manager may not be able to appropriate all the benefits nor bear all the costs. A special case would be where the manager maximizes firm profits. This has little impact on the model, however, and we find the characterization that managers choose $\omega$ to maximize their own returns more realistic, particularly in the poor corporate governance environment in Russia.

In (1), $R(\omega, X)$ is the manager's gross returns to wage arrears. $R_{\omega}=r(X)=$ rate of return to additional payment delay; and $X=$ vector of factors affecting returns (defined so that $r_{x}>0$ ), including illiquidity (effective interest rate faced by the firm) and the ability of managers to appropriate the return.

\footnotetext{
${ }^{13}$ Variation in the effectiveness of legal institutions at the level of whole countries has been argued to affect economic growth and performance (e.g., Mauro, 1995; LaPorta et al, 1998); here we are interested in inter-regional variation in legality.
} 
$C(\omega, \Omega, Z)$ is the cost of wage arrears, where $C_{\omega}=$ marginal cost of wage arrears - resulting from worker effort, quit, strike behavior and from legal penalties - with $C_{\omega}>0$, and $C_{\omega \Omega}<0$ so that the marginal cost is declining with local labor market arrears. $Z=$ vector of other factors affecting $C_{\omega}$ (difficulty of monitoring, strength of worker organization, functioning of the legal system and upward shifters of the quit function, including high alternative relative wages, good local labor market conditions such as a high hiring rate and a low unemployment rate, low specificity of human capital, low worker compensation and fringe benefits, and low search costs), defined so that $C_{\omega Z}>0$.

As discussed above, there are four types of costs: effort and morale, quits, protest behavior and strikes, and legal penalties. We hypothesize that each type of cost has the same general functional relationship with $\omega$ and $\Omega$ : most importantly, that each type of marginal cost of $\omega$ is decreasing in $\Omega$. Using proxies for each type of cost, these assumptions may be directly tested: a worker's arrears should negatively affect her morale and effort and positively affect the probability she quits, strikes, and brings lawsuits; while these effects should be attenuated by the level of arrears in the local labor market.

\subsection{The Reaction Function: $\sigma=f(\Omega, X, Z)$}

The first and second order conditions for the manager's problem (1) are as follows:

$$
\begin{gathered}
\frac{\partial \pi}{\partial \omega}=r(X)-C_{\omega}(\omega, \Omega, Z)=0 \\
\frac{\partial^{2} \pi}{\partial \omega^{2}}=-C_{\omega \omega}<0
\end{gathered}
$$

implying the following optimality condition:

$$
r(X)=C_{\omega}(\varpi, \Omega, Z) .
$$

The reaction function can be derived as

$$
\varpi=f(\Omega, X, Z){ }^{14}
$$

Total differentiation of the first order condition yields:

$$
r_{X} d X-C_{\omega \omega} d \omega-C_{\omega \Omega} d \Omega-C_{\omega Z} d Z=0
$$

Taking each of the exogenous variables $X$, and $Z$ in turn, and making use of the assumptions and the result in equation (3), we can derive the following comparative static results for the impact on $\omega$ :

\footnotetext{
${ }^{14}$ Nothing in our assumptions so far actually constrains this to be a function rather than a correspondence. In our example of a functional form (Section 2.3, below), which is the form we use for estimation, the best-reply correspondence will be univalued however.
} 


$$
\begin{aligned}
& \frac{d \omega}{d X}=\frac{r_{X}}{C_{\omega \omega}}>0 \\
& \frac{d \omega}{d Z}=\frac{-C_{\omega Z}}{C_{\omega \omega}}<0
\end{aligned}
$$

Thus, wage arrears should be positively related to the firm's cost of capital and to the ability of managers to appropriate cash flow and earn private benefits. They should be negatively related to the difficulty of monitoring the worker, to the value of the worker's outside alternatives, to the strength of worker organization, and to the effectiveness of the legal system. Finally, factors that reduce quit rate increase the probability of having wage arrears (specific human capital, employee ownership, fringe benefits, high search and mobility costs, etc.).

Differentiating the reaction function (5) with respect to $\Omega$ (while holding constant the variables in $X$ and $Z$ ) yields:

$$
\frac{d \omega}{d \Omega}=-\frac{\stackrel{C}{\omega \Omega}_{\omega}^{(-)}}{C_{\omega \omega}}>0
$$

Thus, our theory implies that the reaction function displays positive feedback. We obtain the second derivative of the reaction function:

$$
\frac{d^{2} \omega}{d \Omega^{2}}=\frac{C_{\omega \omega \Omega} C_{\omega \Omega}^{(-)}-C_{\omega \Omega \Omega} C_{\omega \omega}^{(+)}}{C_{\omega \omega}{ }^{2}} \underset{<}{<} 0 .
$$

The second derivative may be positive as well as negative. Multiple equilibria are more likely, of course, if the sign switches. Such a case, where the second derivative is initially positive and then turns negative after $\Omega$ exceeds the inflection point $\Omega_{l}$, is shown in Figure 1 .

To motivate this case more fully, we next consider a particular functional form for the cost function, one which permits us to derive a structural reaction function that can be estimated and which we can use to test the hypothesis of positive feedback and the higher-order shape, including the possibility of multiple equilibria.

\subsection{A Particular Functional Form for Estimation}

Consider the following special form of the cost function:

$$
C=\omega \cdot\left(a \omega-b \Omega-c \Omega^{2}+d \Omega^{3}+e Z\right),
$$

which is the simplest that permits the possibility of multiple symmetric Nash equilibria, as we show below. We will again assume that the cost function satisfies the following features: 


$$
\begin{aligned}
& C_{\omega}=2 a \omega-b \Omega-c \Omega^{2}+d \Omega^{3}+e Z=a \omega+\frac{C}{\omega}>0 \\
& C_{\Omega}=\omega\left(-b-2 c \Omega+3 d \Omega^{2}\right)<0 \\
& C_{\omega \omega}=2 a>0 \Rightarrow \quad \Rightarrow \quad a>0 \\
& C_{\omega \Omega}=-b-2 c \Omega+3 d \Omega^{2}=\frac{C_{\Omega}^{(-)}}{\omega}<0 \\
& C_{\omega Z}=e>0
\end{aligned}
$$

Parameters $a$ and $e$ are positive by virtue of our earlier assumptions, but we also hypothesize that $c$ and $d$ are positive, while the sign of $b$ is ambiguous, for reasons that we discuss shortly. The first-order condition of maximizing the objective function implies the equality of marginal return and marginal cost associated with wage arrears:

$$
\begin{gathered}
\max _{\omega} \pi=r \omega-\omega\left(a \omega-b \Omega-c \Omega^{2}+d \Omega^{3}+e Z\right) \\
r=2 a \omega-b \Omega-c \Omega^{2}+d \Omega^{3}+e Z
\end{gathered}
$$

From the first order condition we can derive an estimable reaction function:

$$
\varpi=\frac{b \Omega+c \Omega^{2}-d \Omega^{3}+r-e Z}{2 a},
$$

where $\varpi$ is a cubic function of $\Omega$.

The reaction function exhibits positive feedback:

$$
\frac{\partial \varpi}{\partial \Omega}=\frac{b+2 c \Omega-3 d \Omega^{2}}{2 a}=-\frac{C_{\omega \Omega}^{(-)}}{2 a}>0 .
$$

But the sign of the second derivative is ambiguous:

$$
\frac{\partial^{2} \varpi}{\partial \Omega^{2}}=\frac{c-3 d \Omega}{a} \geq 0
$$

depending on $c, d$, and $\Omega$. For fixed $c$ and $d>0$, the reaction function exhibits a cubic S-shape with inflection point at $\Omega_{i}=c / 3 d$. At lower levels of local labor market arrears $(\Omega<c / 3 d)$ the response function is convex, while at higher levels it is concave. We test these implications on the shape of the reaction function in our empirical analysis below.

\subsection{Equilibrium Wage Arrears}

In symmetric Nash equilibrium, where all firm managers in a local labor market are assumed to face identical return and cost functions and where they take each other's actions as given, the level of firm wage arrears must be equal to the level of regional wage arrears $\left(\omega^{*}=\Omega^{*}\right)$, which implies

$$
-d \omega^{* 3}+c \omega^{*^{2}}+(b-2 a) \omega^{*}+r-e Z=0 .
$$


It is possible to solve this equation analytically for three equilibria in terms of $a, b, c, d, e, r$, and $Z$, but the equations describing the solutions are very long (several pages each). To simplify for illustrative purposes, we note that $r-e Z>0$ implies that even if no other firms in the region have wage arrears $(\Omega=0)$, the net return to wage arrears is still positive, implying $\omega>0$. Since most economies are characterized by punctual payment of wage obligations, we will normalize the results, assuming $r=e Z$, which also permits us to write out analytical solutions for wage arrears equilibria in this special case. Under this assumption, the three symmetric Nash equilibria are:

$$
\begin{gathered}
\omega_{1}^{*}=0 \\
\omega_{2}^{*}=\frac{c-\sqrt{c^{2}+4 d(b-2 a)}}{2 d} \\
\omega_{3}^{*}=\frac{c+\sqrt{c^{2}+4 d(b-2 a)}}{2 d}
\end{gathered}
$$

One equilibrium involves zero firm wage arrears at zero regional wage arrears, while if the other two are to be positive then $4 d(b-2 a)<0$, implying restrictions on $a$ and $b$ such that $b / 2 a<1 .{ }^{15}$ The parameter $b$ may be positive or negative, although our hypotheses imply a generally positive slope of the reaction function. We may characterize $\omega_{1}{ }^{*}$ as the "punctual payment equilibrium," $\omega_{2}{ }^{*}$ as the "critical mass" or "threshold equilibrium," and $\omega_{3}{ }^{*}$ as the "late payment" or "wage arrear equilibrium."

To check these equilibria for stability, we may calculate the slope of the reaction function at the equilibrium points. Stable equilibria should have a reaction function slope less than one:

$$
\left.\frac{\partial \varpi}{\partial \Omega}\right|_{\omega^{*}}=\frac{b+2 c \omega^{*}-3 d \omega^{* 2}}{2 a}<1
$$

which implies

$$
b-2 a+2 c \omega^{*}-3 d \omega^{* 2}<0 .
$$

We may check this condition for each equilibrium in turn. $\omega_{1}^{*}$ is clearly stable:

$$
\left.\frac{\partial \varpi}{\partial \Omega}\right|_{\omega_{1}^{*}}=\frac{b}{2 a}<1
$$

The second equilibrium is unstable: $\left.\frac{\partial \varpi}{\partial \Omega}\right|_{\omega_{2} *}>1$, since upon substitution of $\omega_{2}{ }^{*}$ into (15) we obtain

\footnotetext{
${ }^{15}$ Wage arrears could in principle be negative, i.e. involving advances. But we have not observed economies or even single firms where workers are systematically paid in advance of the contractual date.
} 


$$
\begin{aligned}
b-2 a+2 c\left(\frac{c-\sqrt{c^{2}+4 d(b-2 a)}}{2 d}\right)-3 d\left(\frac{c-\sqrt{c^{2}+4 d(b-2 a)}}{2 d}\right)^{2} \\
=\frac{\left(\sqrt{c^{2}+4 d(b-2 a)}\right)\left(c-\sqrt{c^{2}+4 d(b-2 a)}\right)}{2 d}>0
\end{aligned}
$$

Finally, the third equilibrium is stable: $\left.\frac{\partial \varpi}{\partial \Omega}\right|_{\omega_{3}^{*}}<1$ as

$$
\begin{gathered}
b-2 a+2 c\left(\frac{c+\sqrt{c^{2}+4 d(b-2 a)}}{2 d}\right)-3 d\left(\frac{c+\sqrt{c^{2}+4 d(b-2 a)}}{2 d}\right)^{2} \\
=\frac{\left(\sqrt{c^{2}+4 d(b-2 a)}\right)\left(-c-\sqrt{c^{2}+4 d(b-2 a)}\right)}{2 d}<0
\end{gathered}
$$

Thus, we have found three equilibria and showed that two of them are stable and one is not stable. Figure 2 shows the symmetric Nash equilibria and the dynamics implied by the model. In the range where $\omega_{1}{ }^{*}<\Omega<\omega_{2}{ }^{*}$, a self-interested manager will choose $\omega<\Omega$, so optimizing behavior by all managers will tend to drive down $\Omega$. Beyond $\omega_{2}{ }^{*}$, managerial behavior will tend to push up $\Omega$ until it reaches $\omega_{3}{ }^{*}$, the stable late payment equilibrium.

\subsection{Summary of Testable Hypotheses}

The model contains a number of hypotheses that are testable. First, we can test our hypotheses about the relationship between several types of costs, on the one hand, and the firm and regional wage arrears and their interaction, on the other; most importantly: $E_{\omega \Omega}, Q_{\omega \Omega}, S_{\omega \Omega}$ and $L_{\omega \Omega}<0$. Although these relationships function as assumptions in the theoretical model above, they are the observable aspects of the feedback loops that we argue create increasing returns to the use of wage arrears (over some range). The types of costs we examine include worker quit, effort, and protest (strike) behavior and legal penalties. That the probability or magnitude of each of these responses to arrears should decline in the level of regional arrears, $\Omega$, is a particularly striking feature of the model.

Furthermore, the model implies that the response function is positively sloped $(\partial \omega / \partial \Omega>0)$, that proxies for $X$ raise $\omega$, and that proxies for $Z$ lower $\omega$. Multiple equilibria may arise when the reaction function has an S-shape, so that at low levels of $\Omega, \partial^{2} \omega / \partial \Omega^{2}>0$, while at higher levels $\partial^{2} \omega / \partial \Omega^{2}<0$. The functional form of the manager's objective that we have employed as an example (equation (1') above) suggests a cubic form for the reaction function, with alternating signs on the coefficients in the 
polynomial on $\Omega$. More specifically, we can test that the critical parameters $c$ and $d$ are both positive, while $b / 2 a<1$.

Finally, whether even an S-shaped reaction function would produce multiple equilibria depends on the magnitudes of the parameters. We can use the estimated parameters of the empirical reaction function to simulate symmetric Nash equilibria and calculate the level of arrears consistent with the two stable equilibria and with the unstable critical mass threshold. We report on our empirical efforts in the next section.

\section{Empirical Analysis}

We begin by describing our data sources and using them to analyze the incidence and persistence of wage arrears over the period 1991-98. We then bring the data to bear on the testable assumptions and predictions of our theoretical model of wage arrears, first concerning the several hypothesized costs of arrears and next concerning the shape of the response function. Finally, we use the estimated response function to simulate the symmetric Nash equilibria implied by the data for firms operating in an average Russian local labor market.

\subsection{Data Sources}

Our model analyzes the wage arrears in a particular employment relationship, that is for a particular firm and worker. The data requirements for testing the model, therefore, are quite strenuous, including detailed information on both the firm and the worker. To meet these requirements, this paper analyzes a database combined from several different sources. The principal source, used in most analyses below, consists of the 1994, 1995, 1996, and 1998 waves of a household panel survey, the Russian Longitudinal Mopiforing Survey (RLMS), based on the first national probability sample drawn in the Russian Federation. ${ }^{16}$ The panel structure permits us to examine the persistence and intertemporal effects of wage arrears.

Unfortunately the original RLMS data suffer from a number of crucial limitations for the purpose of examining the determinants of wage arrears. To start with, no RLMS was carried out in 1997, which makes several of our analyses awkward: for instance, when we test the probability of quitting as a function of wage arrears we examine job change from one year to the next, but we are therefore restricted

${ }^{16}$ See Swafford et al (1997). The RLMS data contain results of two longitudinal surveys of more than 10,000 individuals during 1992-1993 (Rounds 1-4) and 1994, 1995, 1996, and 1998 (Rounds 5-8). No information on wage arrears is available from Rounds 1-4, and we restrict our attention in this paper to Rounds 5-8. 
to using only the years 1994, 1995, and 1996 for this analysis. Second, the RLMS contains rather little information on firm-specific and region-specific characteristics that may be important for wage arrears: only crude measures of the size of the enterprise, the year when the enterprise was established, and a few regional indicators are available. No information on the industry of the firm employing the workerrespondent is included in the original, published data. Unionization status, strikes and other forms of protest behavior, penalties for wage arrears, and the regional legal climate are all unmeasured. Finally, quits from the firm are difficult to measure in the original data because of inconsistencies in the job tenure variable (a common problem in household surveys) and ambiguity in the explicit question on jobchanging. ${ }^{17}$

To be able to carry out our analysis satisfactorily, we have extended the original data in a number of ways. First, we have used information provided by most working respondents on their employers (but not included in the published data set) to identify individual firms and the industries in which they operate. An important side-benefit of this was the discovery that respondents working at the same enterprise sometimes provided different answers to questions about their firm. We have cleaned all the original firm variables to make them consistent within firms and across years, and, for most cases, we were also able to code the industry in which the respondent works, a variable that was mostly unavailable to previous researchers. ${ }^{18}$

Another important benefit of our ability to identify the specific employer for most observations was that it enabled us to construct reliable measures of job mobility. We can distinguish job quits reliability from intrafirm mobility, and we can measure job tenure accurately. These are critical variables in our theoretical model.

We extended our information on the characteristics of firms by matching information on industrial firms from the 1993-97 Goskomstat Registries to employees working for industrial firms in that year. These matched data sets enable us to analyze wage arrears as a function of some firm-specific characteristics, most importantly by detailed industry. We also have matched data from the Russian Labor Ministry Inspection Service on the patterns of violations of the Russian Labor Code and how the

\footnotetext{
${ }^{17}$ In 1994 to 1996, a single question permits a "yes" answer both for job changes within firms and for movements across employers. Topel [1991], Brown and Light [1992], and McCue [1996] discuss inconsistencies in tenure and mobility in the PSID in the US, the household survey equivalent of the RLMS.

${ }^{18}$ Some ambiguities of classification prevented us from coding industry for all jobs, but we were able to code the following number of cases: 4826 respondents of 4896 employed in 1994, 4526 of 4575 employed in 1995, and 4348 of 4383 employed in 1996, and 4207 of 4250 employed in 1998.
} 
cases were treated. These data are useful in constructing measures of the effectiveness of the legal enforcement regime in the region.

Finally, we have organized a detailed survey of the employers in the matched data set, collecting information on wage arrears and other aspects of firms for the period 1991-98. Of a total of 530 firms in the Goskomstat Industrial Registry employing RLMS respondents, we have conducted detailed interviews of 380. In this paper, we draw upon the survey information only as a supplement to our other analyses in order to provide alternative estimates of wage arrears over a longer time period (relative to the RLMS data) and to measure the costs of wage arrears in terms of strikes and other worker protest behavior and legal penalties assessed on firms with wage arrears.

\subsection{Measures of Arrears}

Measuring wage arrears faces several problems. In practice, arrears generally accumulate irregularly, with occasional repayments of back wages, and in theory, one would like to measure the present discounted loss due to wage delays taking into account the risk premium associated with the uncertainty of the timing (and probability) of future payment. Such a measure would require detailed information on the salary history of each worker and on his/her discount rate and expectations concerning future payment.

Accounting practice in Russia - both at the individual firm level and by Goskomstat - instead emphasizes the cumulative debt of the firm to its workers, without regard to the timing of the late payments. Workers appear to think of the value of arrears in the same way: the number of monthly salaries that have not yet been paid. This concept has the advantage of being relatively easy to calculate, although workers might forget or make mistakes. We therefore employ two measures drawn from the answers to questions in the RLMS. The first, ARRDUM, is simply a dummy indicating whether the respondent is owed money by his or her employer, which has not "for various reasons" been paid on time ( $1=$ yes, $0=$ no). Table 1 shows that about 40 percent of employed respondents reported they were owed wages at the survey dates in 1994 and 1995, with a rise to about 60 percent in 1996 and 64 percent in $1998 .^{19}$

Individual worker-respondents were also asked to report a second variable in answer to the question, "How many months has this money not been paid to you?" To a Russian worker, the

\footnotetext{
${ }^{19}$ These results are consistent with Goskomstat's aggregate figures (based on enterprise reports).
} 
interpretation of this variable, which we call ARRMOS, is clearly the number of unpaid monthly wages, independent of the timing of the nonpayments, or, in other words, the cumulative overdue wage debt owed by the firm to the worker. Because the stock measure is somewhat imperfect, as discussed above, and also because of some possibility of ambiguity or slip of memory with ARRMOS, we report some estimates using both ARRDUM and ARRMOS. ${ }^{20}$ In general the cross-time and cross-industry patterns in the intensity of arrears are consistent with those in their incidence.

The unconditional mean of ARRMOS rose slightly in 1995, then jumped in 1996 and again in 1998; the distribution of the variable shows pronounced rightward shifts in 1996 and 1998. If the proportion of workers with two or more months of arrears was only about 25 percent in 1994 and 1995, it had increased to nearly 44 percent by 1996 and 50 percent by late 1998 . Conditional on having arrears, the expected magnitude rose from 2.75 to more than 4.8 months. Clearly the overall increase in arrears reflects both a spreading of the contagion to previously unaffected workers and a worsened condition for those already affected.

Table 1 also provides strong evidence of persistence in arrears, here defined simply as the conditional probability that an individual will be owed money in a particular year, conditional that is on having reported arrears in prior years. For instance, the probability of having arrears in 1995 was more than twice as great for individuals experiencing arrears in 1994 as for those who did not. The probability of having arrears in 1996 conditional on having arrears in both 1994 and 1995, was nearly 90 percent, as was that of having arrears in 1998 conditional on having arrears in all three of the earlier years (shown in the last row in the top panel of the table).

The table also shows the conditional mean of ARRMOS, conditional on the prior year's ARRMOS. Among respondents with over 6 months of arrears in 1995, the mean number of months was 7.7 in 1996; the analogous figure for 1998 conditional on 1996 was 9.4. Again, the data appear to reflect both a widening and a deepening of the arrears crisis over this period.

Table 2 shows similar information based on the survey of industrial firms. One advantage of these data is the longer time series: 1991 to 1998. Starting from a negligible level in 1991, the fraction

\footnotetext{
${ }^{20}$ One potential source of ambiguity could arise from the practice of paying workers in-kind, either using goods produced by the company or those received by the company in some barter arrangement with another one. The standard practice, however, is for workers to formally accept (by signature) such in-kind payments in lieu of cash, thus neither the firm nor the workers should confuse them with arrears. This practice is also an interesting method of labor adjustment in Russia, but we defer its analysis for future research.
} 
of firms reporting arrears and the magnitude of the unpaid debts grew steadily over the whole period. The distribution of the magnitude, ARRMOS, here defined as the average number of monthly wage bills owed by the firm in each year, shows a steady rightward shift.

In our empirical tests of the model's hypotheses, below, our measure of individual wage arrears, $\omega_{i}$, is ARRMOS for the individual $i$ from the RLMS. We also construct $\Omega_{i}$ from the RLMS by aggregating ARRMOS up to the rayon level, each time omitting the particular firm for which the individual worker is employed. While analyses of Russian regions are frequently conducted at the oblast level, we feel that the rayon much better reflects the scope of the local labor market. ${ }^{21}$

\subsection{Sample Characteristics}

Table 3 examines the firm and employee characteristics of the employed sample in the final RLMS round, autumn 1998, divided into those owed back wages by their employers and those not. Substantial regional variation existed at the rayon (county) level: some parts of the Moscow Oblast had trivial levels of arrears, while in other regions arrears were almost universal. Although not shown in the table, results calculated for the City of Moscow show that 28.7 percent of employees were owed money and the mean (ARRMOS) was .9 months; these mostly reflect arrears of the Federal Government. Variation across industries was also large, although somewhat muted by comparison with that for regions. Wage arrears had higher incidence and magnitude in agriculture and heavy industrial sectors (particularly the Military-Industrial Complex), as well as in services financed through the state budget (education and health). In a new and rapidly developing sector like banking and finance, however, arrears were very small.

The variable "non-public sector" is defined on the basis of industries that are part of the budgetary sphere in Russia (ministries and federal agencies). We suspect that these arrears may be driven by a different process from the one that our model attempts to capture, thus the sample for our empirical tests on the shape of the reaction function, below, is restricted to non-public sector workers. (The tests of costs use the entire sample because the hypothesized behavior - changes in effort, quits, and strikes - should apply in all firms.) In Section 4.1, we will briefly return to the subject of arrears in the federal sector.

\footnotetext{
${ }^{21}$ There are 89 oblasts or "subjects" (including autonomous republics, etc.) of the Russian Federation, some of which are larger than Texas, others of which are rather small. The next lower administrative level is the rayon, of which there are an average of 22 per oblast, thus approximately the same size as a county in the U.S. or U.K. There are 52 rayons, thus 52 different values of $\Omega$ in each year of the RLMS sample.
} 
The table also displays the composition of the arrears and nonarrears samples in 1998 across a number of personal characteristics. Workers with arrears tend to have lower hourly wages and family incomes. ${ }^{22}$ Wage arrears are also more commonly found among men and are negatively associated with schooling. Arrears are negatively associated with schooling, and positively with age and job tenure; these may reflect considerations of mobility costs and outside opportunities. ${ }^{23}$ Concerning variation across occupations, craft workers and operators and assemblers tend to experience the highest rates, while managers have the lowest, although the rate is high even for this occupation.

Table 4 draws on the enterprise survey to show some characteristics of firms with and without wage arrears in 1998. While the industry patterns are similar to those in the individual data, the relationship of arrears with union density is striking: arrears are relatively less common in firms with very low and with 100 percent union density, while they are more common at intermediate levels. At the bottom end, this is likely a reflection of the presence of new firms, or of substantial restructuring leading to the dissolving of the formerly dominant unions, but the top end is less clear. Perhaps the ability of some unions to maintain complete membership of all employees in their firms reflects organizing strength that would also be useful in resisting wage arrears. In any event, the descriptive statistics suggest that we should permit the effect of union density to enter in non-linear fashion.

The table also shows some measures of the functioning of the legal environment in which managers make their wage arrear decisions. These are drawn from data of the Russian Ministry of Labor's Inspection Service. They pertain to the oblast, or subject of the Russian Federation, in which the firm is located in the year 1997. The first variable reports the ratio of the uncollected fines to the total number of fines assessed on managers due to labor violations. We interpret this variable as reflecting (inversely) the strength of the legal system in carrying out at least those punishments it does assess: managers would need to fear relatively little in regions in which this ratio is high. Although the mean of the variable is low, the standard deviation is substantial. The second variable is the ratio of the number

\footnotetext{
${ }^{22}$ The hourly wage rate is computed as the ratio of the contractual wage in the previous month to the usual hours of work in the previous month. The contractual wage is available in the RLMS only in 1998, while the earlier RLMS questionnaires only requested actual earnings in the previous month. This is a problem for workers with wage arrears, however, as monthly earnings may be quite volatile: lower than the contractual wage when new wage debts are incurred and higher than the contractual wage when they are paid off. For the earlier years, therefore, we have followed Earle and Sabirianova (1998), imputing the contractual wage based on the ratio of the total wage debt owed the worker to the number of monthly wages owed (ARRMOS).

${ }^{23}$ The implied arrears-tenure relationship (also obtained in Earle and Sabirianova, 1998; and Lehmann, Wadsworth, and Acquisti, 1998) could be spurious if an employer has incurred arrears in the past but more recently has tended to pay regular monthly wages. Unfortunately, the data (particularly on the timing of arrears) are insufficient to permit us to assess the quantitative importance of this possibility.
} 
of cases where wage arrears were paid off to the number of violations found by the Inspection Service. This variable we interpret as directly related to the enforcement regime, and its low level indicates that even when the policing agency has discovered a violation it is rather unlikely to be remedied. The lower level for firms reporting wage arrears, relative to those reporting none, is consistent with legal congestion preventing the Inspection Service from enforcing the Labor Law and contracts. These two variables are included in the $Z$ vector of controls when we estimate the cost function for legal penalties.

Tables 5 and 6 show proxy variables for the four types of costs of arrears discussed in the model. The variables for "hours of work," "desire to switch jobs," and "quits," are measured from the RLMS, while "strikes and other forms of protest" and "legal penalties" are drawn from the enterprise survey. The first two variables proxy effort decisions by workers: work hours are actual hours on the job, and "desire to switch jobs" is a dummy variable in response to the direct question. We argue that these proxy for morale and job satisfaction, variables likely to influence effort; in addition, it is sometimes argued that Russian workers reduce their hours in response to arrears (Aslund, 1997), so we wish to estimate this relationship, including its variation with $\Omega$. The table shows that, while hours show little systematic variation across respondents reporting arrears and those reporting none, a substantially larger fraction of those with arrears are more likely to say they desire a different job.

Quits are defined as leaving the employer in the next year; the measure is based on our extensive cleaning of the variable representing the current employer each year, as discussed above, and not on the unreliable tenure variable. The table shows the figures conditional on wage arrears in the previous year, with the overall rate of the one-year probability at about 20 percent and little difference across workers with and without arrears.

Both strikes and penalties, shown in Table 6, are negligible in the early 1990s and then rise gradually throughout the period. The low levels in the years 1991-95 lead us to aggregate these years in the estimations below. Strikes are much more common in firms reporting wage arrears than those not, and wage arrears were by far the most commonly cited reason for strikes by firms reporting them in response to a direct question.

\subsection{Testing Hypotheses on the Costs of Arrears}

Our first tests of the model concern our assumptions on the nature of the relationship between costs to the manager of using wage arrears and the level of arrears in the firm and in the local labor 
market environment. Recall from Section 2.1 that $C_{\omega}>0, C_{\Omega}<0$, and $C_{\omega \Omega}<0$. Our argument here is that there are a number of potential costs to using wage arrears, and that each exhibits positive feedback in that the sense that the cost of arrears are reduced on the margin when other firms in the local labor market tend to have higher arrears. If this is correct, then each of these types of costs represents a feedback loop that has contributes to self-propagation of wage arrears.

Table 7 shows estimates for the functions using our proxies for effort and morale costs as dependent variables. The key results are that the impact of $\omega$ on a worker's hours of work and desire to switch jobs is reduced by $\Omega$ (so that $E_{\omega \Omega}<0$ ). Computing $\partial($ Hours) $/ \partial \omega$ at alternative levels of $\Omega$, we find that workers in low- $\Omega$ regions reduce their hours in response to their own arrears, so that if $\Omega=0$, hours fall 1.88 hours per month for each one month increase in $\omega$. But $\partial($ Hours $) / \partial \omega$ falls as $\Omega$ rises, and at $\Omega=7.7$ months, the effect vanishes entirely (indeed the simple linear estimates suggest a positive response for higher levels of $\Omega$ ). Similarly, the probability that an individual reports a desire to switch jobs, our proxy for job satisfaction, increases by 3.1 percent for each month of $\omega$ in regions where $\Omega=0$. Given an overall average probability of 36 percent (Table 5), this effect implies that an individual in a low arrears region with six months arrears would be 50 percent more likely to desire a job change compared to an otherwise identical neighbor with no wage arrears. But the effect declines with $\Omega$ such that the point estimates suggest it becomes negligible at about $\Omega=10$.

Table 7 results concerning the vector of $Z$ controls in the regressions are fairly standard: The hours equations shows a slight tendency towards backward-bending in the hourly wage rate (the magnitude suggests that a 1000 ruble increase in the wage, about 11 percent, would decrease hours by 1.25 hours per month), while non-labor (family) income has a negative sign, and male gender, schooling, and age are all positively associated with hours. The regression for desire to switch jobs shows that the probability declines with the contractual wage and with job tenure.

Table 8 shows the estimated quit function. Again, the results imply $Q_{\omega}>0, Q_{\Omega}<0$, and $Q_{\omega \Omega}<0$ for this component of costs. The estimated derivative of the quit probability with respect to $\omega$ implies that workers quit in response to their own arrears when $\Omega$ is less than about three months, but when $\Omega$ is greater, the quit response to $\omega$ becomes negative. We take this clear finding in the data as strong evidence for our hypothesis that wage arrears are strategic complements for managers of firms operating 
in the same local labor market. Results for the $Z$ controls show that male gender is positively associated while schooling and tenure are negatively associated with the quit probability.

The results from estimation with dependent variables equal to the last two types of costs - strikes and legal penalties - are shown in Table 9. In these regressions, we use the firm data and specify the $Z$ vector to include unionization in the former and proxies for the legal environment in the latter. Again the data show that $\Omega$ tends to lessen the impact of $\omega$ on worker response: $S_{\omega \Omega}<0$ and $L_{\omega \Omega}<0$. With respect to strikes, the probability of protesting wage arrears declines to zero when $\Omega=5$; with respect to legal penalties the probability reaches zero at $\Omega=4$. The effect of unions on the strike probability has an inverse U-shape, being lowest for union density less than 10 percent and equal to 100 percent. In the former case, worker organization is simply weak, while we interpret the latter as reflecting old unions, inherited from the communist period, that do little to advance their members' interests.

With respect to the legal environment measures, the fraction of cases when managers failed to pay assessed fines on time is estimated to have a negative impact on the probability of legal penalties, which we interpret as a reflection of the relationship of wage arrear penalties with the effectiveness of local legal institutions. The negative impact of the second variable, the fraction of cases when arrears were paid off after the violation was discovered, is a bit more puzzling: it may simply reflect the fact that penalties are less likely to be assessed when managers quickly pay after they are found out. In any case, the results for all four components of costs strongly support the hypothesis of a positive feedback loop in each case, suggesting there may be increasing returns to the use of wage arrears.

\subsection{Estimating the Reaction Function}

Next we turn to a direct estimation of the reaction function (5'), where the $Z$ vector of other characteristics of workers and firms affecting wage arrears is decomposed into observable and unobservable components. This leads directly to our estimating equation:

$$
\omega_{i}=\beta_{0}+\beta_{1} \Omega_{i}+\beta_{2} \Omega_{i}^{2}+\beta_{3} \Omega_{i}^{3}+\beta_{4} X_{i}+\beta_{5} Z_{i}^{\prime}+\xi_{i},
$$

where we use the subscript $i$ to index individual workers, and where $\beta_{1}=b / 2 a, \beta_{2}=c / 2 a$, and $\beta_{3}=-d / 2 a$, $\beta_{4}=r^{\prime}\left(X_{i}\right) / 2 a$ and $\beta_{5}=-e / 2 a$. We have decomposed the vector of $Z$ controls to include a constant, $\beta_{0}$, a vector of observable characteristics, $Z_{i}^{\prime}$, and a resid $\mu$ l reflecting an unobserved component in the cost function, $\varepsilon_{i}$; thus, $Z_{i}=\beta_{0}+Z_{i}{ }^{\prime}+\varepsilon_{i}$, and $\xi_{i}=\varepsilon_{i} / 2 a{ }^{24}$ Clearly the model is under-identified in that we

\footnotetext{
${ }^{24}$ This assumes no constant term in the $r(X)$ function; if there is such a term, then our estimated intercept would have a slightly different meaning, but the key model results would still have the same interpretation.
} 
cannot recover the values of the theoretical reaction function (5') from these estimates. We can infer their signs, however.

Because the Russian economy was hit by many shocks during this period (as we discuss further below), we estimate the function year by year. ${ }^{25}$ The results are shown in Table 10. In all years, the derivative $\partial \omega / \partial \Omega$ is estimated to be positive, implying an upward-sloping reaction function over the relevant range, except for some slight initial declines. From the estimated function, we calculate the initial decline as .32 months in 1994, .65 in 1995, and 1.4 in 1998, although the estimated $\beta_{l}$ is hardly statistically significantly different from zero in the first two years. Thus, the data provide strong evidence of positive feedback in the reaction function, and thus of the strategic complementarity of wage arrears within a local labor market.

One of the less obvious predictions of the theoretical model, emerging from the discussion around equations (13), was that $b / 2 a=\beta_{l}<1$. This implication is satisfied by the estimates in all four years, and in all years except 1996 we can reject the hypothesis that $\beta_{l}=1$ at the one percent level. This is also a necessary condition for stability of the extreme equilibria.

The point estimates of $c$ and $d$ are also consistent with the theoretical model in all four years, although they are not always statistically significant. In 1995 and 1998, the relationship between azand $\Omega$ also shows an S-shape, suggesting the possibility of multiple equilibria, which we return to below. ${ }^{26}$

Apart from these most important implications of the model, the finding of the positive impact of job tenure is notable in all four years, and the estimated magnitude increases over the period. This result, which was also noted by Lehmann, Wadsworth, and Acquisti (1998) and Earle and Sabirianova (1998), is consistent with the results from the quit and effort functions: workers with higher firm-specific human capital are less likely to quit and reduce effort in response to arrears, and managers appear to take this behavior into account when setting their wage arrears policies.

\subsection{Simulating Symmetric Nash Equilibria}

Figure 3 graphs the estimated reaction function for each year, taking the average of $\beta_{0}+\beta_{4} X_{i}^{\prime}+$ $\beta_{5} Z_{i}^{\prime}$ across all individuals in the sample, which then becomes the intercept for the plotted relationship. Under the assumption of symmetric Nash behavior in local labor markets, it is straightforward in

\footnotetext{
${ }^{25}$ As mentioned above, we restrict the sample for the reaction function estimation to the non-public sector, as public agencies, schools and hospitals are unlikely to have much discretion over their wage payments.

${ }^{26} \mathrm{We}$ also estimated higher-order polynomials in $\Omega$, but the higher order-terms were statistically insignificant.
} 
principle to solve the estimated reaction functions for the set of average equilibria across regions. Figure 3 does this in the simplest way, by finding the intersection between the reaction function and a $45^{\circ}$ ray from the origin.

As is evident from the figure, the results suggest that there were multiple equilibria in 1995 and 1998. In 1995, the average punctual payment equilibrium in Russian regions involved one monthly wage debt, the critical mass was 2.7 months, and the late payment equilibrium 6.6 months. In 1998, the situation worsened, and the average punctual payment equilibrium moved out to just under two months, the critical mass to 5.8 months, and the late payment equilibrium to 9.6 months.

In the years with the clear S-shaped functions, the estimates imply stability of the extreme equilibria $\omega_{1}^{*}$ and $\omega_{3}^{*}$ and instability of the threshold $\omega_{2}^{*}$. Thus, the data not only provide support for the model's most important predictions of positive feedback and multiple equilibria, but also for some of the model's crucial details.

In 1994 and 1996, however, the reaction function does not display a clear S-shape (although it is strongly positive). We interpret this as a reflection of instability, making it difficult to observe the reaction function as it was shifting. Concerning 1994, this was early in the process, when wage arrears were rising rapidly. By contrast, the RLMS data in Table 1 show rather little change from 1994 to 1995 , which may explain our ability to get more precise estimates for the latter year.

The 1996 figures also reflect substantial turmoil; recall that the RLMS figures, again in Table 1, show a nearly 50 percent increase in the fraction of the employed respondents reporting wage arrears from 1995 to 1996 . The fall of 1996 (the RLMS is conducted during October-November) was a particularly unstable period for wage arrears: it came just a few months after the July election, prior to which President Yeltsin had made a big effort to pay late wages of government employees as part of his electoral campaign, and after which payment arrears immediately soared as budgetary considerations again took a higher priority in the Kremlin. We return to the subject of budgetary arrears in the next subsection.

\section{Discussion}

In this section, we discuss some remaining issues involving equilibrium selection, robustness and the welfare impact of wage arrears, and we conclude with a brief summary pointing to the broader relevance of our work for understanding economic institutions. 


\subsection{Equilibrium Selection and Robustness}

Two natural questions arise concerning our analysis of equilibrium wage arrears. The first pertains to equilibrium selection: how do countries or regions get into the punctual payment or the late payment equilibrium? More concretely, what spurred the wage arrears problem in Russia to begin with? Given our argument that the persistence of the practice requires a critical mass of participating employers, it seems to us that a single large employer may have helped to set a standard of late-payment, making the practice more acceptable and thus moving the entire economy towards the late-payment regime. The only employer that we can think of that might be large enough to bring about this shift is the largest Russian employer, and indeed one that was growing during this period: the government itself. $^{27}$

The mechanism that we believe brought this about was a massive sequestration of budgetary funds by the Ministry of Finance. After the burst of inflation following price liberalization in 1992, the Russian Government was under heavy pressure to reduce the budget deficit; this also featured strongly in IMF loan conditionality at the time. Although comprehensive accounting of the extent of sequestration have not been made available, according to the Institute for the Economy in Transition $(1994$, p. 35) every expenditure line in the fourth quarter of the 1993 federal budget was sequestered by 20 percent. Rather than shutting the government down, as occasionally happens in the U.S. during budgetary disputes between the President and the Congress, the Russian government continued to operate, government contractors continued to supply government orders, and state employees continued coming to work even when they began to be paid irregularly. We believe that this was the "small event" that set the path-dependent development of wage arrears in motion: when such a big labor market player as the government ceases to pay its workers on time, this sets a new standard for other employers, decreasing their costs of using wage arrears and helping to legitimize and raise the perceived "normalcy" of this otherwise peculiar practice.

Unfortunately, detailed data on the early stages of wage arrears in 1992-93 are unavailable to substantiate fully our allegation that the state played the role of leader, and in our analysis we are able only to examine the incidence and magnitude of arrears by industry. By the time of the surveys from

\footnotetext{
${ }^{27}$ According to OECD (1997), employment in public administration grew steadily from 663,000 in 1990 to 1.087 mln in 1995, or from .88 to 1.64 percent as a fraction of total employment.
} 
which we draw our individual data (late 1994), wage arrears were already widespread, and our firm-level data cover only the industrial sector. Furthermore, although our analysis shows the forces leading to persistence of arrears once they have been established, from the existing data it is not apparent why arrears became established in some regions but not others, whether due to larger shares of government and government suppliers, greater shocks, other regional conditions, or random factors. These are issues deserving further research and data collection.

A second question concerns the robustness of the equilibria we have described. Two aspects are potentially relevant: defection by firms, and migration by workers. Taking these in order, our analysis has focused on symmetric Nash equilibria, but what prevents some firm, say a new entrant, from violating the late-payment norm, for instance by offering workers a lower wage, but paid regularly ontime? Our model shows that identical firms will not defect from the late payment equilibrium, but in practice there is likely to be heterogeneity, particularly in the case of new start-ups. Firms with profitable opportunities seeking to hire new employees may try to build a reputation for punctual payment, if workers care about this characteristic of their jobs.

While such a process appears to be occurring in a number of regions of Russia, in order to explain why it does not unravel the late payment equilibrium in regions with persistently high arrears we must call upon other aspects of the Russian environment, including the severe recession and the continual instability and illiquidity. The large fall in output and consumption has reduced the profitability of entry, and the continual instability has made it difficult for firms to establish reputations. We can imagine a signaling game in which there are two types of firms: in one type, where prospects are poor, managers simply try to steal wages; while in the others, which have profitable projects, they try to pay them and to build a reputation to increase effort and reduce turnover. But the type of firm is unobservable to workers, and all managers announce (as they do in reality) their most sincere intentions to pay wages as soon "as soon as the firm has money." In this situation, the ability of the second type of managers to distinguish themselves from the first type amounts to the possibility for existence of a separating equilibrium. If economic instability is so great that occasional shocks hit every firm with some probability, rendering them temporarily unable to pay, then firms cannot build a reputation and workers may not be able to distinguish the firms in practice. This analysis is outside our formal model, 
and it is very difficult to verify empirically, but it does explain why a late payment equilibrium may be robust even when new entry and firm heterogeneity are permitted.

A second robustness issue concerns the possibility for inter-regional migration by workers. If indeed some regions are in the punctual payment, while others are stuck in the late payment equilibrium, why do workers not move from the latter to the former? To some extent, this may happen, of course, but an oft-noted feature of Russian labor markets is the low geographic mobility of labor. To some extent, the low levels of migration to cities may be explained by the continued functioning of the propiska system, whereby new residents must pay large fees to register. But it is also likely associated with information problems and with poorly functioning housing markets, as well as liquidity problems of Russian workers. $^{28}$ Thus, it would appear that Russian regions are poorly integrated, and worker mobility across regions acts only slowly to break down regional differences.

\subsection{Welfare Considerations}

Given our argument that the wage payment practice may exhibit multiple equilibria, what are the welfare characteristics of the late versus the punctual payment equilibrium? Layard and Richter (1995) and OECD (1997) have praised the use of wage arrears as a way of achieving wage flexibility and low unemployment in Russia. Leaving aside the question of the social desirability of wage flexibility, however, it seems to us that wage arrears are far from being a socially efficient mechanism for bringing about a given effective change in the real wage.

As a first welfare consideration, it should be noted that wage arrears are unevenly spread across regions and households, for reasons we have argued, and thus their social consequences tend to be concentrated in certain groups. Secondly, wage arrears reduce utility more than equivalent wage cuts, because of the associated uncertainty concerning the timing and probability of eventual payment. Thirdly, we have argued that arrears may sometimes actually impede mobility, particularly where arrears are widespread in the local labor market; these areas are also likely to be those where mobility geographic and industrial - is most needed. Thus, wage arrears may actually retard the reallocation of labor that is critical to the transition process.

It seems to us, however, that the major consideration in a normative evaluation of arrears stems from the fact that labor contracts are the most important contracts for most individuals. When those

\footnotetext{
${ }^{28}$ See Mitchneck and Plane (1995) or Heleniak (1997) for discussions of internal migration in Russia.
} 
contracts are not respected and enforced, this reduces confidence in other labor and nonlabor contracts into which the individual might enter. In short, wage arrears may undermine the development of contract enforcement and rule of law. North (1990) has argued that these are critical institutions in promoting impersonal exchange, which in turn explains much of differences in economic growth and performance. Our analysis provides a case study of the lock-in of an institution that we believe, for similar reasons to North's, to be inimical to the healthy development of a market economy in Russia - in which case it is truly paradoxical if the Russian government's attempt to balance the budget was a critical spark igniting the wage arrear explosion in the first place.

\subsection{Conclusion}

This paper has developed and tested some key features of a model of institutional lock-in. The model provided a number of testable hypotheses, including the functional relationship between several types of costs of arrears and the impact of arrears in the local labor market environment, the positive feedback in the reaction function, and the possibility under certain circumstances of multiple equilibria. With the assumption of a particular functional form for the manager's costs of wage arrears, we derived an estimable reaction function.

Our empirical analysis provides clear evidence for the key hypotheses in our theory. To start with, higher wage arrears in the local labor market attenuate the negative impact of a worker's arrears on his/her morale and effort (as proxied by hours of work and reported desire to change jobs), the positive impact on the quit probability, and the positive impact on the strike probability; in addition, they reduce the impact of the level of a firm's arrears on the probability that a legal penalty will be assessed. Furthermore, the analysis demonstrates strong evidence of positive feedback in the manager's choice of wage arrears from the behavior of other firms operating in the same local labor market. Rational managers do indeed appear to take into account the wage arrears behavior of neighboring employers when choosing their own strategies. The evidence is also highly suggestive of multiple equilibria in wage arrears. For two of four years in our sample, the reaction function displays a clear S-shape, and the parameters are such as to imply that the average Russian region does indeed face multiple equilibria. For the other two years, it seems to us that the highly unstable situation could have led to rapidly shifting reaction functions that would have obscured the true shape of the function. 
There are some important caveats to this work. While we are able to measure several of the feedback loops fairly directly (or at least examine some reasonable proxies for each), our results for the reaction function reflect the average behavior across a diverse set of regions. With a larger data set and several years of stability it could become possible to estimate the different sets of equilibria in different regions of Russia. But the results we have presented are illustrative of the method that can be used for addressing this issue, and we believe they go a considerable distance toward demonstrating the existence of multiple equilibria in the peculiar institution of wage arrears.

Finally, our analysis of wage arrears in Russia is relevant for understanding economic institutions more generally. The feedback mechanisms that we highlight in our model may apply to a wide variety of other economic practices, for example labor market practices such as forms of compensation (stock options, fringe benefits), promotional schemes (up-or-out, internal labor markets), and unionization. Sociological research on organizations has taken the tendency for such types of behavior to converge on a uniform practice, or "institutional isomorphism," as a primary research question, but it has not explained how the convergence takes place within a framework of individual optimization, nor has it provided empirical estimates of the feedback loops and reaction functions that underly the "macro-micro interactions." Moreover, the transition economies show us the possibility of alternative institutional paths, different from those found in developed market systems. In our example, the practice of paying wages on time has received little attention in standard models of the employment relationship, but Russia shows that under some conditions late payment may rather become the norm. We would argue that the timeliness of wage payments can be usefully analyzed as an institution, and we have provided evidence for a specific set of self-reinforcing mechanisms that could tend to make arrears in wage payments persist. That punctual wage payment is the norm in market economies may be attributed to the strength of court enforcement (including well-functioning bankruptcy procedures) and the importance of reputational considerations for firms operating in relatively stable labor markets and economic environments. We believe that studying Russian wage arrears contributes to raising awareness of the many dimensions of employment contracts in a wide variety of economic contexts, and that it heightens appreciation of the web of institutions that support - or undermine - contracting in the labor market. 


\section{References}

Akerlof, George A., "A Theory of Social Custom, of Which Unemployment May be One Consequence," Quarterly Journal of Economics, XCIV (1980), 749-75.

Akerlof, George A., "Labor Contracts as Partial Gift Exchange," Quarterly Journal of Economics, XCVII (1982), 543-69.

Aoki, Masa, Toward a Comparative Institutional Analysis, manuscript, Stanford University (2000).

Arthur, Brian W., "Competing Technologies, Increasing Returns, and Lock-in by Historical Events," Economic Journal, XCIX (1989), 116-31.

Aslund, Anders. "Social Problems and Policy in Postcommunist Russia." In Ethan.B. Kapstein and M. Mandelbaum, eds., Sustaining the Transition: The Social Safety Net in Postcommunist Europe. New York: Council on Foreign Relations (1997).

Bikhchandani, Sushil, David Hirshleifer, and Ivo Welch, "Learning from the Behavior of Others: Conformity, Fads, and Informational Cascades," Journal of Economic Perspectives, XII (1998), $151-70$.

Brown, James N., and Audrey Light, "Interpreting Panel Data on Job Tenure," Journal of Labor Economics, X (1992), 219-57.

Chamley, Christophe, "Coordinating Regime Switches," Quarterly Journal of Economics, CXIV (August 1999), 869-905.

Cooper, Russell, and Andrew John, "Coordinating Coordinating Failures in Keynsian Models," Quarterly Journal of Economics, CIII (August 1988), 441-63.

David, Paul A., "Clio and the Economics of QWERTY," American Economic Review, LXXV (1985), 332-37.

Desai, Padma, and Todd L. Idson, "Wage Arrears in Russia,” Mimeo, 1998.

Dewatripont, Mathias, and Gerard Roland, "Transition as a Process of Large-Scale Institutional Change," Economics of Transition, IV (1996), 1-30.

DiMaggio, Paul J., and Walter W. Powell, "The Iron Cage Revisited: Institutional Isomorphism and Collective Rationality in Organizational Fields," American Sociological Review, 48 (1983), 147-60.

Earle, John S., and Richard Rose, "Ownership Transformation, Economic Behavior, and Political Attitudes in Russia," CISAC Working Paper (1996).

Earle, John S., and Klara Sabirianova, "Understanding Wage Arrears in Russia," SITE Working Paper, No. 139 (1998).

Fligstein, Neil, "The Spread of the Multidivisional Form among Large Firms, 1919-1979," American Sociological Review, L (1985), 377-91.

Frye, Timothy, and Andrei Shleifer, "The Invisible Hand and the Grabbing Hand," American Economic Review, 87 (May 1997), 354-8.

Gaddy, Clifford G., and Barry W. Ickes, "Russia's Virtual Economy," Foreign Affairs, LXXVII (September-October 1998), 52-67. 
Gimpelson, Vladimir, "The Politics of Labour Market Adjustment: The Case of Russia," Collegium Budapest Discussion Paper, No. 54 (November 1998).

Glaeser, Edward, Bruce Sacerdote, and Jose A. Scheinkman, "Crime and Social Interactions," Quarterly Journal of Economics, CXI (1996), 507-48.

Granovetter, Mark, "Threshold Models of Collective Behavior," American Journal of Sociology, LXXXIII (1978), 1420-43.

Greif, Avner, "Contract Enforceability and Economic Institutions in Early Trade: the Maghribi Traders' Coalition," American Economic Review, Vol. 83, No. 3 (June 1993), 525-48.

Greif, Avner, and Eugene Kandel, "Contract Enforcement Institutions: Historical Perspective and Current Status in Russia," in Edward Lazear (editor), Economic Transition in Eastern Europe and Russia: Realities of Reform, Stanford: Hoover Institution Press (1995).

Greif, Avner, Paul Milgrom, and Barry R. Weingast, "Coordination, Commitment, and Enforcement: The Case of the Merchant Guild," Journal of Political Economy, Vol. 102, No. 4 (August 1994), 745-776.

Heleniak, Timothy, "Internal Migration in Russia During the Economic Transition," Post-Soviet Geography and Economics, Vol. 38, No. 2 (February 1997), 81-104.

Hendley, Kathryn; Ickes, Barry; Murrell, Peter; and Ryterman, Randi. "Observations on the Use of Law by Russian Enterprises.” Post-Soviet Affairs, 13(1) (January-March 1997), 19-41.

Hoff, Karla, "Beyond Rosenstein-Rodan: The Modern Theory of Underdevelopment Traps," Proceedings of the World Bank Annual Conference on Development Economics 2000 (forthcoming).

Institute for the Economy in Transition, Russian Economy in 1993: Trends and Prospects. Moscow: Institute for the Economy in Transition, 1994.

Katz, Michael, and Carl Shapiro, "Technology Adoption in the Presence of Network Externalities," Journal of Political Economy, XCIV (1986), 822-41.

Kennan, John, "The Economics of Strikes," Chapter 19 in Orley Ashenfelter and Richard Layard (editors), Handbook of Labor Economics, Amsterdam: Elsevier Science Publishers (1986).

Kiyotaki, Nobuhiro, "Multiple Expectational Equilibria under Monopolistic Competition," Quarterly Journal of Economics, CIII (November 1988), 695-713.

La Porta, Rafael, Florencio Lopez de Silanes, Andrei Shleifer, and Robert Vishny, "Law and Finance," Journal of Political Economy, Vol. 106, No. 6, 1113-55, 1998.

Layard, Richard, and Andrea Richter, "How Much Unemployment is Needed for Restructuring: The Russian Experience," Economics of Transition, III (1995), 35-58.

Lee, Kevin C., and M. Hashem Pesaran, "The Role of Sectoral Interactions in Wage Determination in the UK Economy," Economic Journal, Vol. 103, Issue 416 (January 1993), 21-55.

Lehmann, Hartmut, Jonathan Wadsworth, and Alessandro Acquisti, "Grime and Punishment: Job Insecurity and Wage Arrears in the Russian Federation," Journal of Comparative Economics, 1999.

Levine, David I., and Richard J. Parkin, "Work Organization, Employment Security, and Macroeconomic Stability," Journal of Economic Behavior and Organization, Vol. 24, No. 3 (August 1994), 251-71.

Levinson, Harold M., "Pattern Bargaining: A Case Study of the Automobile Workers," Quarterly Journal of Economics, LXXIV(2) (May 1960), 296-317. 
Lindbeck, Assar, Sten Nyberg, and Jorgen Weibull, "Social Norms and Economic Incentives in the Welfare State," Quarterly Journal of Economics, CXIV (1999), 1-35.

Malcomson, James M., "Contracts, Hold-Up, and Labor Markets," Journal of Economic Literature, XXXV(4) (1997), 1916-57.

Mauro, Paolo, “Corruption and Growth," Quarterly Journal of Economics, CX (1995), 681-712.

McCue, Kristin, "Promotions and Wage Growth,” Journal of Labor Economics, XIV (1996), 175-209.

McMillan, John, and Christopher Woodruff, "Interfirm Relationship and Informal Credit in Vietnam," Quarterly Journal of Economics, CXIV (4) (November 1999), 1285-1320.

Milgrom, Paul R., Douglass North, and Barry R. Weingast, "The Role of Institutions in the Revival of Trade: The Medieval Law Merchant, Private Judges, and the Champagne Fairs," Economics and Politics 1 (1990), 1-23.

Milgrom, Paul, and John Roberts, "Rationalizability, Learning, and Equilibrium in Games with Strategic Complementarities," Econometrica, LVIII (6) (November 1990), 1255-77.

Mitchneck, Beth, and David A. Plane, "Migration and the Quasi-Labor Market in Russia," International Regional Science Review, Vol. 18, No. 3 (1995), 267-88.

Murphy, Kevin M., Andrei Shleifer, and Robert W. Vishny, "Industrialization and the Big Push," Journal of Political Economy, Vol. 97, No. 5 (October 1989), 1003-26.

Murrell, Peter, "Evolution in Economics and in the Economic Reform of the Centrally Planned Economies." in C.C. Clague and G. Rausser, eds., The Emergence of Market Economies in Eastern Europe. Cambridge, Mass. and Oxford: Blackwell, 1992.

North, Douglass C., Institutions, Institutional Change, and Economic Performance, New York: Cambridge University Press, 1990.

OECD Economic Surveys 1997-1998: The Russian Federation. Paris: OECD, 1997.

Rosenstein-Rodan, Paul, "Problems of Industrialization of Eastern and Southeastern Europe," Economic Journal, 53 (June-September 1943), 202-11.

Russian Economic Trends, VIII(1), 1999.

Sah, Raaj K, "Social Osmosis and Patterns of Crime," Journal of Political Economy, XCIX (1991), 1272-95.

Shapiro, Carl, and Joseph E. Stiglitz, "Equilibrium Unemployment as a Worker Discipline Device," American Economic Review, LXXIV (1984), 433-44.

Stiglitz, Joseph E., "Alternative Theories of Wage Determination and Unemployment in LDCs: The Labor Turnover Model," Quarterly Journal of Economics, LXXXVIII (1974), 194-227.

Stiglitz, Joseph E., "Equilibrium Wage Distributions," Economic Journal, XCV (September 1985), 595618.

Swafford, M., et al, "Sample of the Russian Federation Rounds V, VI, and VII of the Russian Longitudinal Monitoring Survey," Technical Report, 1997.

Topel, Robert, "Specific Capital, Mobility, and Wages: Wages Rise with Job Seniority," Journal of Political Economy, XCIX (1991), 145-76. 
Young, Peyton H., “The Evolution of Conventions,” Econometrica, LXI (1993), 57-84.

Young, Peyton H., "The Economics of Convention," Journal of Economic Perspectives, X (1996), 10522. 
Table I: Incidence, Magnitude and Persistence of Wage Arrears (Household Survey, RLMS)

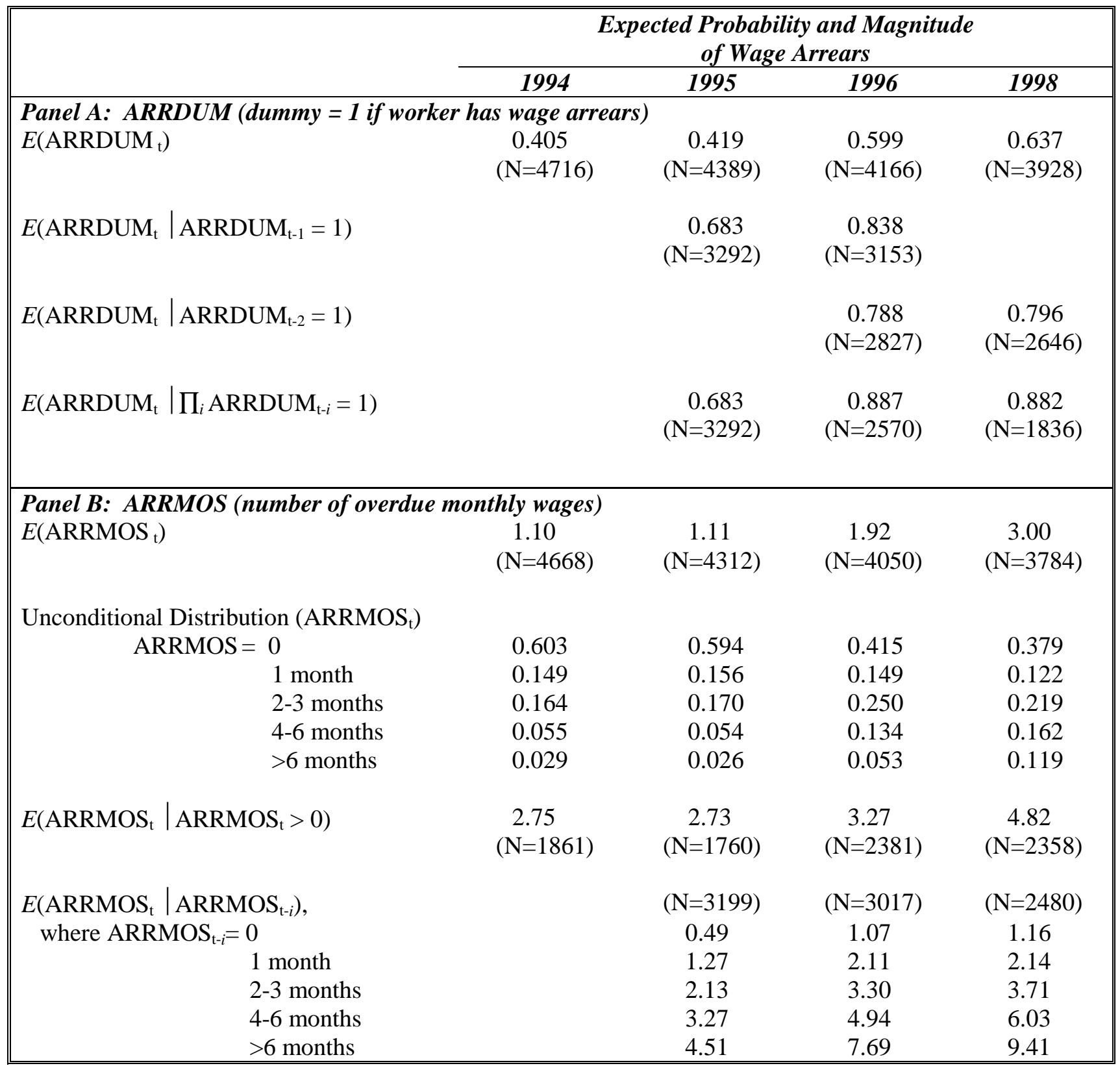

Notes: ARRDUM $_{t}=1$ if an employed respondent reports overdue wages on his/her primary job, 0 if no wages are overdue in year $t$. ARRMOS $_{t}=$ number of monthly wages reported overdue by an employed respondent in year t. Sample consists of all employed respondents in the respective files of the RLMS. Sample sizes are shown in parentheses for number of valid responses for ARRDUM and ARRMOS, respectively; sample sizes vary primarily due to attrition and replacement in the RLMS panel, and secondarily because of missing values for some respondents. RLMS = Russian Longitudinal Monitoring Survey. 
Table 2: Incidence, Magnitude and State Dependence of Wage Arrears

(Survey of Industrial Firms)

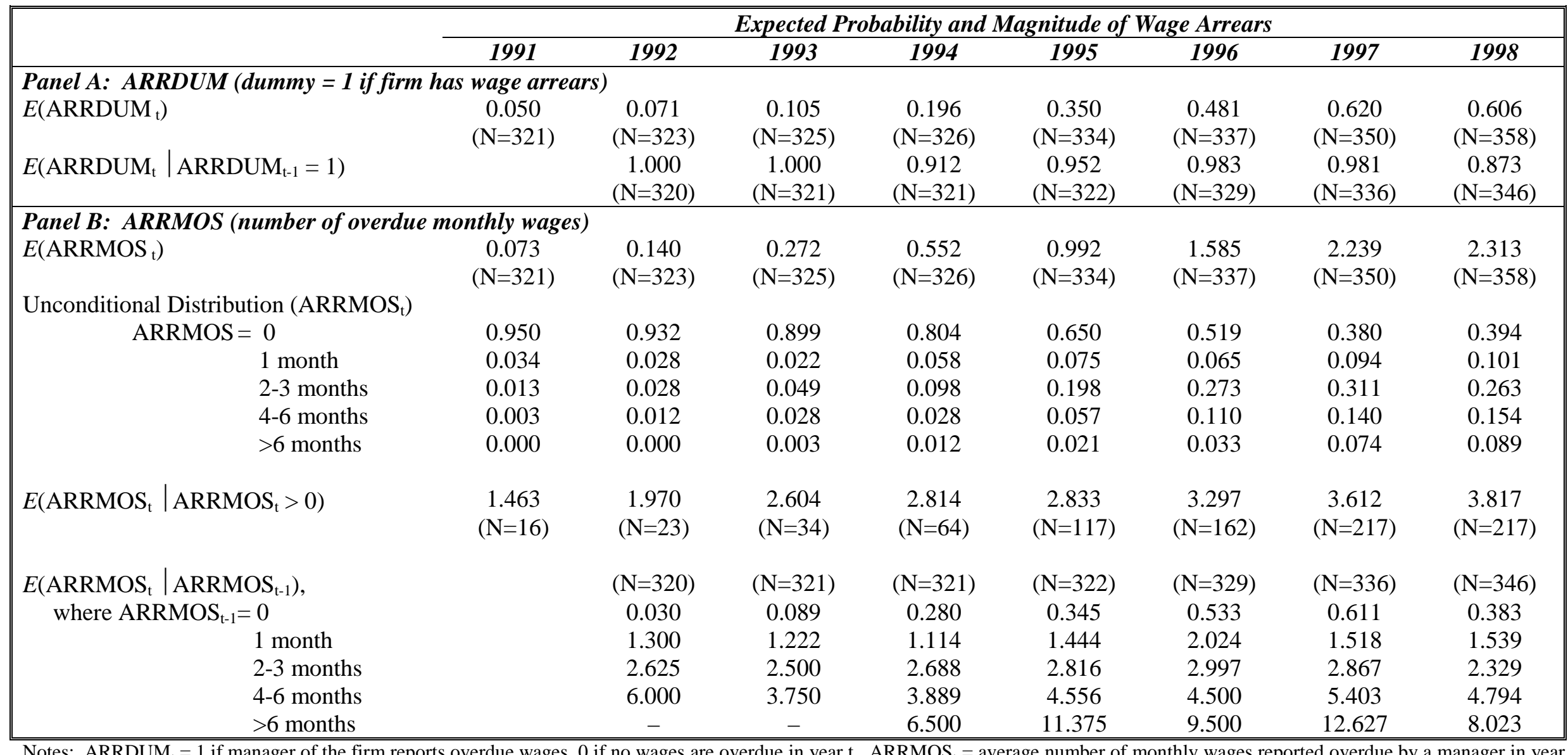

t. Sample consists of industrial firms. Sample sizes are shown in parentheses for number of valid responses for ARRDUM and ARRMOS, respectively. 
Table 3: Characteristics of the Individual Sample, 1998

\begin{tabular}{|c|c|c|c|c|c|}
\hline & $\begin{array}{c}\text { Respondents } \\
\text { Reporting } \\
\text { Wage } \\
\text { Arrears }\end{array}$ & $\begin{array}{c}\text { Respondents } \\
\text { Reporting } \\
\text { No Wage } \\
\text { Arrears } \\
\end{array}$ & & $\begin{array}{c}\text { Respondents } \\
\text { Reporting } \\
\text { Wage } \\
\text { Arrears } \\
\end{array}$ & $\begin{array}{c}\text { Respondents } \\
\text { Reporting } \\
\text { No Wage } \\
\text { Arrears } \\
\end{array}$ \\
\hline Regions & & & Non-Public Sector & 0.607 & 0.740 \\
\hline Moscow and St. Petersburg & 0.043 & 0.151 & Hourly Wage Rate (rub.) & 5.651 & 7.190 \\
\hline Northern West & 0.097 & 0.055 & & $(8.303)$ & $(8.441)$ \\
\hline Central Region & 0.186 & 0.243 & Total Family Income (rub.) & 580.669 & 659.012 \\
\hline Volga & 0.205 & 0.134 & & $(1026.256)$ & $(929.320)$ \\
\hline North Caucasus & 0.119 & 0.114 & Male & 0.476 & 0.446 \\
\hline Urals & 0.155 & 0.135 & Schooling (years) & 11.905 & 12.149 \\
\hline Siberia & 0.195 & 0.169 & & $(2.428)$ & $(2.392)$ \\
\hline Industry & & & Age (years) & 39.610 & 38.551 \\
\hline Energy & 0.016 & 0.011 & & $(11.625)$ & $(12.039)$ \\
\hline Fuel & 0.020 & 0.033 & Tenure (years) & 8.579 & 6.860 \\
\hline Metallurgy & 0.026 & 0.027 & & (9.364) & $(8.397)$ \\
\hline Chemicals & 0.008 & 0.019 & Occupation & & \\
\hline Machine Building & 0.091 & 0.053 & Managers & 0.030 & 0.052 \\
\hline Military Complex & 0.036 & 0.016 & Professionals & 0.141 & 0.148 \\
\hline Wood and Building Materials & 0.045 & 0.020 & Technicians & 0.197 & 0.182 \\
\hline Light and Food & 0.039 & 0.074 & Clerks & 0.067 & 0.084 \\
\hline Agriculture & 0.102 & 0.047 & Service Workers & 0.084 & 0.129 \\
\hline Transportation & 0.071 & 0.092 & Craft Workers & 0.170 & 0.155 \\
\hline Construction & 0.072 & 0.043 & Operators and Assemblers & 0.181 & 0.148 \\
\hline Trade & 0.037 & 0.171 & Unskilled Workers & 0.110 & 0.100 \\
\hline Finance and Commerce & 0.007 & 0.069 & Army & 0.019 & 0.002 \\
\hline Housing & 0.061 & 0.047 & & & \\
\hline Health & 0.114 & 0.058 & & & \\
\hline Social Services & 0.159 & 0.127 & & & \\
\hline Government & 0.080 & 0.061 & & & \\
\hline Other & 0.017 & 0.031 & & $\mathrm{~N}=2138$ & $\mathrm{~N}=1321$ \\
\hline
\end{tabular}

Note: Standard deviations are in parentheses. Sample consists of all employed respondents in the 1998 RLMS. 
Table 4: Characteristics of the Firm Sample, 1998

\begin{tabular}{|l|cc|}
\hline & $\begin{array}{c}\text { Firms Reporting } \\
\text { Wage Arrears }\end{array}$ & $\begin{array}{c}\text { Firms Reporting } \\
\text { No Wage Arrears }\end{array}$ \\
\hline Industry & & \\
Energy \& Fuel & 0.115 & 0.075 \\
Metallurgy \& Chemicals & 0.101 & 0.105 \\
Machine Building & 0.466 & 0.299 \\
Wood and Building Materials & 0.101 & 0.082 \\
Light & 0.091 & 0.127 \\
Food & 0.115 & 0.239 \\
Other & 0.010 & 0.075 \\
Union Density & & \\
0-9\% & 0.101 & 0.157 \\
10-39\% & 0.072 & 0.037 \\
40-69\% & 0.130 & 0.097 \\
70-99\% & 0.428 & 0.388 \\
100\% & 0.269 & 0.321 \\
Legal Environment & & 0.098 \\
Fraction of cases when & 0.093 & $(0.089)$ \\
managers failed to pay assessed & $(0.085)$ & \\
fines on time & & 0.231 \\
& & $0.171)$ \\
Fraction of cases when arrears & 0.195 & $\mathrm{~N}=134$ \\
were paid off after violation was & $(0.125)$ & \\
discovered & & $\mathrm{N}=208$ \\
\hline
\end{tabular}

Note: Standard deviations are in parentheses. Sample consists of industrial firms.

Table 5: Measures of Worker Behavior, 1994-1998

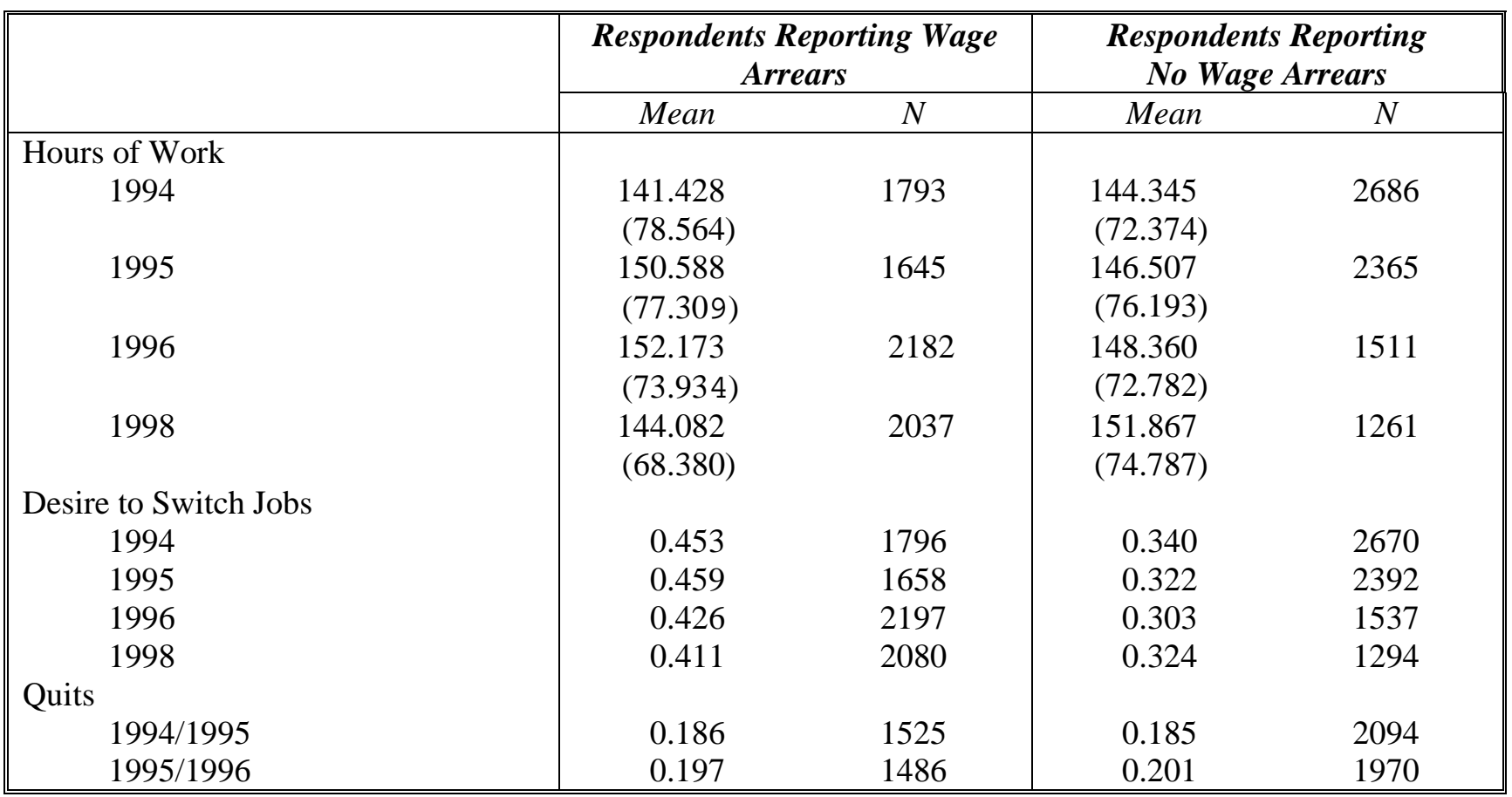

Note: Standard deviations are in parentheses. Sample consists of all employed respondents. 
Table 6: Measures of Cost of Wage Arrears, 1991-1998

\begin{tabular}{||c|cc|cc|}
\hline \multirow{2}{*}{} & Firms Reporting Wage Arrears & \multicolumn{2}{c|}{$\begin{array}{c}\text { Firms Reporting } \\
\text { No Wage Arrears }\end{array}$} \\
\cline { 2 - 5 } & Mean & $N$ & \multicolumn{2}{|c|}{ Mean } \\
\hline Strikes & & & & \\
1991 & 0.000 & 15 & 0.003 & 287 \\
1992 & 0.000 & 22 & 0.000 & 282 \\
1993 & 0.031 & 32 & 0.000 & 275 \\
1994 & 0.034 & 59 & 0.004 & 251 \\
1995 & 0.037 & 108 & 0.000 & 208 \\
1996 & 0.039 & 153 & 0.006 & 166 \\
1997 & 0.074 & 204 & 0.000 & 127 \\
1998 & 0.111 & 208 & 0.015 & 134 \\
1991 & & & & \\
1992 & 0.000 & 16 & - & 258 \\
1993 & 0.000 & 22 & - & 254 \\
1994 & 0.033 & 30 & - & 250 \\
1995 & 0.018 & 56 & - & 225 \\
1996 & 0.020 & 98 & - & 188 \\
1997 & 0.029 & 140 & - & 115 \\
1998 & 0.022 & 184 & - & 123 \\
\hline
\end{tabular}

Note: Sample consists of industrial firms. 
Table 7: Costs of Wages Arrears: Proxies for Effort and Morale

\begin{tabular}{|c|c|c|c|c|c|}
\hline \multirow[t]{2}{*}{ Independent Variables } & \multicolumn{2}{|c|}{$\begin{array}{c}\text { Hours of Work } \\
\text { (Tobit) }\end{array}$} & \multicolumn{2}{|c|}{$\begin{array}{c}\text { Desire to Switch Jobs } \\
\text { (Probit) }\end{array}$} & \multirow[t]{2}{*}{ Mean } \\
\hline & Coeff. & $t$ & $d f / d X$ & $t$ & \\
\hline $\begin{array}{l}\omega \text { (number of monthly wages } \\
\text { overdue) }\end{array}$ & $-1.883 * * *$ & -5.588 & $0.031 * * *$ & 14.594 & 1.700 \\
\hline$\Omega$ (regional arrears environment) & -0.453 & -0.697 & $-0.013 * * *$ & -3.136 & 1.694 \\
\hline$\omega * \Omega$ & $0.245 * * *$ & 3.510 & $-0.003 * * *$ & -7.211 & 4.627 \\
\hline \multicolumn{6}{|l|}{ Regions (Siberia is omitted) } \\
\hline Moscow and St. Petersburg & -0.447 & -0.174 & $0.067 * * *$ & 3.967 & 0.097 \\
\hline Northern West & -3.646 & -1.388 & $0.055^{* * *}$ & 3.253 & 0.079 \\
\hline Central Region & $-7.379 * * *$ & -3.517 & 0.007 & 0.488 & 0.192 \\
\hline Volga & $-5.271 * *$ & -2.524 & 0.018 & 1.324 & 0.170 \\
\hline North Caucasus & $-3.909 *$ & -1.687 & -0.007 & -0.441 & 0.121 \\
\hline Urals & $-7.151 * * *$ & -3.258 & $-0.029 * *$ & -2.096 & 0.148 \\
\hline Hourly Wage Rate (rub.) /10 & $-12.530^{* * * *}$ & -25.605 & $-0.022 * * *$ & -6.314 & 0.894 \\
\hline Family Income (rub.) / 1000 & $-2.462 * * *$ & -5.120 & -0.001 & -0.336 & 0.880 \\
\hline \multicolumn{6}{|l|}{ Individual Characteristics } \\
\hline Male & $35.231 * * *$ & 23.647 & $-0.036 * * *$ & -3.737 & 0.477 \\
\hline Schooling (years) & $1.233 * * *$ & 3.819 & $0.012 * * *$ & 5.690 & 11.784 \\
\hline Age (years) & $0.646^{* * *}$ & 10.458 & $-0.008 * * *$ & -19.350 & 39.229 \\
\hline Tenure (years) & $-0.296 * * *$ & -3.728 & $-0.006^{* * *}$ & -10.917 & 8.458 \\
\hline \multicolumn{6}{|l|}{$\begin{array}{l}\text { Occupation (craft workers are } \\
\text { omitted) }\end{array}$} \\
\hline Managers & $47.871 * * *$ & 12.795 & $-0.172 * * *$ & -7.724 & 0.037 \\
\hline Professionals & $4.711^{*}$ & 1.765 & $-0.117 * * *$ & -7.138 & 0.145 \\
\hline Technicians & $8.488 * * *$ & 3.649 & $-0.111 * * *$ & -7.787 & 0.173 \\
\hline Clerks & $14.528 * * *$ & 4.882 & $-0.092 * * *$ & -5.043 & 0.070 \\
\hline Service Workers & $26.490 * * *$ & 10.148 & $-0.041 * *$ & -2.535 & 0.095 \\
\hline Operators and Assemblers & $15.195 * * *$ & 7.279 & -0.021 & -1.620 & 0.172 \\
\hline Unskilled Workers & $8.392 * * *$ & 3.341 & $0.103 * * *$ & 6.256 & 0.110 \\
\hline Army & $52.831 * * *$ & 8.879 & $-0.096 * * *$ & -2.717 & 0.012 \\
\hline Year95 & 2.382 & 1.419 & -0.007 & -0.679 & 0.259 \\
\hline Year96 & $7.205^{* * *}$ & 4.031 & -0.016 & -1.363 & 0.239 \\
\hline Year98 & -0.513 & -0.247 & -0.022 & -1.627 & 0.216 \\
\hline \multirow[t]{2}{*}{ Intercept } & $96.592 * * *$ & 18.646 & & & \\
\hline & \multicolumn{2}{|c|}{$\begin{array}{c}\mathrm{N}=15480 \\
\mathrm{LR} \operatorname{chi} 2(26)=1770.69\end{array}$} & \multicolumn{2}{|c|}{$\begin{array}{c}\mathrm{N}=15624 \\
\mathrm{LR} \operatorname{chi} 2(26)=1507.89\end{array}$} & \\
\hline
\end{tabular}

Notes: *** - significant at the $1 \%$ level, $* *$ - significant at the $5 \%$ level; *-significant at the $10 \%$ level. Sample consists of all employed respondents. 
Table 8: Quit Function, 1994-1996

(Probit Estimates)

\begin{tabular}{|c|c|c|c|}
\hline Independent Variables & $d F / d X$ & $t$ & Mean \\
\hline$\omega$ (number of monthly wages overdue) & $0.010 * * *$ & 2.945 & 1.189 \\
\hline$\Omega$ (regional arrears environment) & $-0.013^{*}$ & -1.837 & 1.134 \\
\hline$\omega * \Omega$ & $-0.003 * *$ & -2.364 & 2.051 \\
\hline \multicolumn{4}{|l|}{ Regions (Siberia is omitted) } \\
\hline Moscow and St. Petersburg & 0.016 & 0.787 & 0.085 \\
\hline Northern West & $-0.032 *$ & -1.693 & 0.079 \\
\hline Central Region & -0.006 & -0.394 & 0.191 \\
\hline Volga & $-0.041 * * *$ & -2.715 & 0.180 \\
\hline North Caucasus & 0.003 & 0.176 & 0.121 \\
\hline Urals & -0.010 & -0.640 & 0.154 \\
\hline Hourly Wage Rate (rub.) / 10 & -0.001 & -0.200 & 0.948 \\
\hline Total Family Income (rub.) / 1000 & 0.004 & 1.330 & 0.947 \\
\hline Male & $0.035 * * *$ & 3.143 & 0.472 \\
\hline Schooling (years) & $-0.007 * * *$ & -2.855 & 11.651 \\
\hline Age (years) & -0.000 & -0.204 & 39.579 \\
\hline Tenure (years) & $-0.006 * * *$ & -9.458 & 8.956 \\
\hline \multicolumn{4}{|l|}{ Occupation (craft workers are omitted) } \\
\hline Managers & $-0.045^{*}$ & -1.644 & 0.033 \\
\hline Professionals & $-0.059 * * *$ & -3.137 & 0.142 \\
\hline Technicians & $-0.029 *$ & -1.745 & 0.172 \\
\hline Clerks & -0.031 & -1.468 & 0.071 \\
\hline Service Workers & -0.010 & -0.519 & 0.085 \\
\hline Operators and Assemblers & $-0.038 * * *$ & -2.651 & 0.183 \\
\hline Unskilled Workers & 0.022 & 1.221 & 0.112 \\
\hline Army & $-0.091 * *$ & -2.217 & 0.011 \\
\hline \multirow[t]{2}{*}{ Year94 } & -0.012 & -1.305 & 0.512 \\
\hline & \multicolumn{3}{|c|}{$\mathrm{N}=7108$} \\
\hline
\end{tabular}

Notes: t-statistics are reported in parentheses; $*_{*}^{*}$ - significant at the $1 \%$ level, ** - significant at the 5\% level; *significant at the $10 \%$ level. Sample consists of all employed respondents. 
Table 9: Costs of Wages Arrears: Strikes and Legal Penalties

\begin{tabular}{|c|c|c|c|c|c|}
\hline \multirow[t]{2}{*}{ Independent Variables } & \multicolumn{2}{|c|}{$\begin{array}{l}\text { Strikes } \\
\text { (Probit) }\end{array}$} & \multicolumn{2}{|c|}{$\begin{array}{c}\text { Legal Penalties } \\
\text { (Probit) }\end{array}$} & \multirow[t]{2}{*}{ Mean } \\
\hline & $d F / d X$ & $t$ & $d F / d X$ & $t$ & \\
\hline$\omega$ (number of monthly wages overdue) & $0.005 * * *$ & 5.803 & $0.0004 * * *$ & 3.817 & 1.046 \\
\hline$\Omega$ (regional arrears environment) & 0.003 & 1.625 & 0.0003 & 1.528 & 1.049 \\
\hline$\omega^{*} \Omega$ & $-0.001 * * *$ & -3.501 & $-0.0001 * *$ & -2.352 & 2.520 \\
\hline \multicolumn{6}{|l|}{ Industry (Food Industry is omitted) } \\
\hline Energy \& Fuel & $0.019 *$ & 1.828 & - & - & 0.093 \\
\hline Metallurgy \& Chemicals & 0.010 & 1.121 & 0.0018 & 1.371 & 0.109 \\
\hline Machine Building & 0.004 & 0.650 & 0.0006 & 1.082 & 0.389 \\
\hline Wood and Building Materials & 0.005 & 0.603 & $0.0052 * *$ & 2.555 & 0.091 \\
\hline Light & 0.009 & 1.041 & - & - & 0.113 \\
\hline Other & 0.013 & 1.053 & - & - & 0.040 \\
\hline \multicolumn{6}{|l|}{ Union Density } \\
\hline $10-39 \%$ & 0.035 & 1.485 & - & - & 0.042 \\
\hline $40-69 \%$ & $0.045^{*}$ & 1.883 & - & - & 0.094 \\
\hline $70-99 \%$ & $0.021 *$ & 1.796 & - & - & 0.430 \\
\hline $100 \%$ & 0.015 & 1.251 & - & - & 0.384 \\
\hline \multicolumn{6}{|l|}{ Legal Environment } \\
\hline $\begin{array}{l}\text { Fraction of cases when } \\
\text { managers failed to pay assessed } \\
\text { fines on time }\end{array}$ & - & - & $-0.0124 * * *$ & -3.046 & 0.093 \\
\hline $\begin{array}{l}\text { Fraction of cases when arrears } \\
\text { were paid off after violation was } \\
\text { discovered }\end{array}$ & - & - & $-0.0032 * *$ & -2.108 & 0.217 \\
\hline Year96 & 0.004 & 0.769 & 0.0006 & 0.849 & 0.126 \\
\hline Year97 & $0.016 * *$ & 2.195 & 0.0007 & 0.799 & 0.131 \\
\hline \multirow[t]{2}{*}{ Year98 } & $0.034 * * *$ & 3.792 & 0.0015 & 1.450 & 0.135 \\
\hline & $\begin{array}{r}\mathrm{N}= \\
\text { LR } \operatorname{chi} 2(\end{array}$ & $\begin{array}{l}531 \\
=131.44\end{array}$ & $\begin{array}{c}\mathrm{N}= \\
\text { LR } \operatorname{chi} 2(1\end{array}$ & $\begin{array}{l}295 \\
)=69.39\end{array}$ & \\
\hline
\end{tabular}

Notes: t-statistics are reported in parentheses; *** - significant at the $1 \%$ level, ** - significant at the 5\% level; * significant at the $10 \%$ level. Sample consists of industrial firms. 
Table 10: Wage Arrear Reaction Function 1994-1998, OLS

\begin{tabular}{|c|c|c|c|c|}
\hline $\begin{array}{c}\text { Dependent Variable - w(number of } \\
\text { overdue monthly wages) }\end{array}$ & 1994 & 1995 & 1996 & 1998 \\
\hline $\begin{array}{l}\Omega(\text { regional arrears environment }) \\
\Omega^{2} \\
\Omega^{3}\end{array}$ & $\begin{array}{l}-0.311 \\
(-0.720) \\
0.525^{* *} \\
(1.974) \\
-0.073 \\
(-1.643)\end{array}$ & $\begin{array}{l}-0.806 * * * \\
(-2.751) \\
0.683 * * * \\
(4.887) \\
-0.066^{* * *} \\
(-4.228)\end{array}$ & $\begin{array}{c}0.473 \\
(1.085) \\
0.073 \\
(0.426) \\
-0.003 \\
(-0.146)\end{array}$ & $\begin{array}{l}-0.984 * \\
(-1.937) \\
0.400 * * * \\
(3.690) \\
-0.023 * * * \\
(-3.603)\end{array}$ \\
\hline $\begin{array}{l}\text { Legal Environment } \\
\text { Fraction of cases when managers } \\
\text { failed to pay assessed fines on } \\
\text { time }\end{array}$ & $\begin{array}{l}-0.932 \\
(-1.372)\end{array}$ & $\begin{array}{l}-2.127 * * * \\
(-3.084)\end{array}$ & $\begin{array}{l}-1.829 * \\
(-1.903)\end{array}$ & $\begin{array}{l}-5.269 * * * \\
(-2.711)\end{array}$ \\
\hline $\begin{array}{l}\text { Fraction of cases when arrears } \\
\text { were paid off after violation was } \\
\text { discovered }\end{array}$ & $\begin{array}{l}-0.253 \\
(-0.911)\end{array}$ & $\begin{array}{l}-0.618^{* *} \\
(-2.195)\end{array}$ & $\begin{array}{l}-0.369 \\
(-0.920)\end{array}$ & $\begin{array}{l}-1.369 \\
(-1.610)\end{array}$ \\
\hline Individual Characteristics & & & & \\
\hline Male & $\begin{array}{l}-0.012 \\
(-0.136)\end{array}$ & $\begin{array}{c}0.144 \\
(1.613)\end{array}$ & $\begin{array}{r}0.213^{*} \\
(1.748)\end{array}$ & $\begin{array}{l}0.858 * * * \\
(3.361)\end{array}$ \\
\hline Schooling (years) & $\begin{array}{c}0.013 \\
(0.703)\end{array}$ & $\begin{array}{c}0.000 \\
(0.023)\end{array}$ & $\begin{array}{c}0.003 \\
(0.103)\end{array}$ & $\begin{array}{c}0.040 \\
(0.682)\end{array}$ \\
\hline Age (years) & $\begin{array}{l}-0.004 \\
(-0.960)\end{array}$ & $\begin{array}{c}0.004 \\
(1.177)\end{array}$ & $\begin{array}{l}-0.001 \\
(-0.289)\end{array}$ & $\begin{array}{c}0.010 \\
(0.970)\end{array}$ \\
\hline Tenure (years) & $\begin{array}{l}0.022 * * * \\
(4.560)\end{array}$ & $\begin{array}{l}0.019 * * * \\
(4.167)\end{array}$ & $\begin{array}{l}0.032 * * * \\
(5.019)\end{array}$ & $\begin{array}{l}0.047 * * * \\
(3.494)\end{array}$ \\
\hline Occupations (craft workers are omitted) & & & & \\
\hline Managers & $\begin{array}{c}0.100 \\
(0.474)\end{array}$ & $\begin{array}{l}-0.487 * * \\
(-2.440)\end{array}$ & $\begin{array}{l}-0.198 \\
(-0.681)\end{array}$ & $\begin{array}{c}0.360 \\
(0.610)\end{array}$ \\
\hline Professionals & $\begin{array}{l}-0.048 \\
(-0.281)\end{array}$ & $\begin{array}{c}0.080 \\
(0.472)\end{array}$ & $\begin{array}{l}-0.058 \\
(-0.244)\end{array}$ & $\begin{array}{l}0.156 \\
(0.309)\end{array}$ \\
\hline Technicians & $\begin{array}{c}0.069 \\
(0.475)\end{array}$ & $\begin{array}{l}-0.088 \\
(-0.613)\end{array}$ & $\begin{array}{l}-0.254 \\
(-1.261)\end{array}$ & $\begin{array}{c}0.295 \\
(0.718)\end{array}$ \\
\hline Clerks & $\begin{array}{l}-0.208 \\
(-1.167)\end{array}$ & $\begin{array}{l}-0.131 \\
(-0.764)\end{array}$ & $\begin{array}{l}-0.145 \\
(-0.605)\end{array}$ & $\begin{array}{l}1.001 * * \\
(2.013)\end{array}$ \\
\hline Service Workers & $\begin{array}{l}-0.349^{*} \\
(-1.913)\end{array}$ & $\begin{array}{l}-0.347 * * \\
(-1.984)\end{array}$ & $\begin{array}{l}-0.188 \\
(-0.814)\end{array}$ & $\begin{array}{l}1.029 * * \\
(2.067)\end{array}$ \\
\hline Operators and Assemblers & $\begin{array}{c}0.202^{*} \\
(1.815)\end{array}$ & $\begin{array}{l}-0.114 \\
(-1.033)\end{array}$ & $\begin{array}{c}0.098 \\
(0.631)\end{array}$ & $\begin{array}{l}0.751 * * \\
(2.301)\end{array}$ \\
\hline Unskilled Workers & $\begin{array}{c}-0.106 \\
(-0.738)\end{array}$ & $\begin{array}{c}0.036 \\
(0.249)\end{array}$ & $\begin{array}{c}-0.040 \\
(-0.206)\end{array}$ & $\begin{array}{c}0.632 \\
(1.502)\end{array}$ \\
\hline Army & $\begin{array}{l}-1.090 \\
(-0.516)\end{array}$ & $\begin{array}{c}0.842 \\
(0.423)\end{array}$ & $\begin{array}{c}1.712 \\
(0.917)\end{array}$ & $\begin{array}{c}-1.827 \\
(-0.508)\end{array}$ \\
\hline Intercept & $\begin{array}{r}0.817^{*} \\
(1.948) \\
\end{array}$ & $\begin{array}{l}1.103^{* * *} \\
(2.785) \\
\end{array}$ & $\begin{array}{c}-0.054 \\
(-0.090) \\
\end{array}$ & $\begin{array}{c}0.046 \\
(0.036) \\
\end{array}$ \\
\hline & $\begin{array}{c}\mathrm{N}=3271 \\
\mathrm{~F}(39,3231)= \\
16.76 \\
\mathrm{R}^{2}=0.168\end{array}$ & $\begin{array}{c}\mathrm{N}=2980 \\
\mathrm{~F}(39,2940)= \\
34.46 \\
\mathrm{R}^{2}=0.314\end{array}$ & $\begin{array}{c}\mathrm{N}=2665 \\
\mathrm{~F}(39,2625)= \\
21.22 \\
\mathrm{R}^{2}=0.240\end{array}$ & $\begin{array}{c}\mathrm{N}=2275 \\
\mathrm{~F}(39,2235)= \\
15.69 \\
\mathrm{R}^{2}=0.215\end{array}$ \\
\hline
\end{tabular}

Notes: t-statistics are reported in parentheses; $* * *$ - significant at the $1 \%$ level, $* *$ - significant at the $5 \%$ level; $*_{-}$ significant at the $10 \%$ level. Other controls included (but not shown here) are regional dummies ( 7 categories) and industry dummies (17 categories). Sample is restricted to respondents employed in non-public sector. 


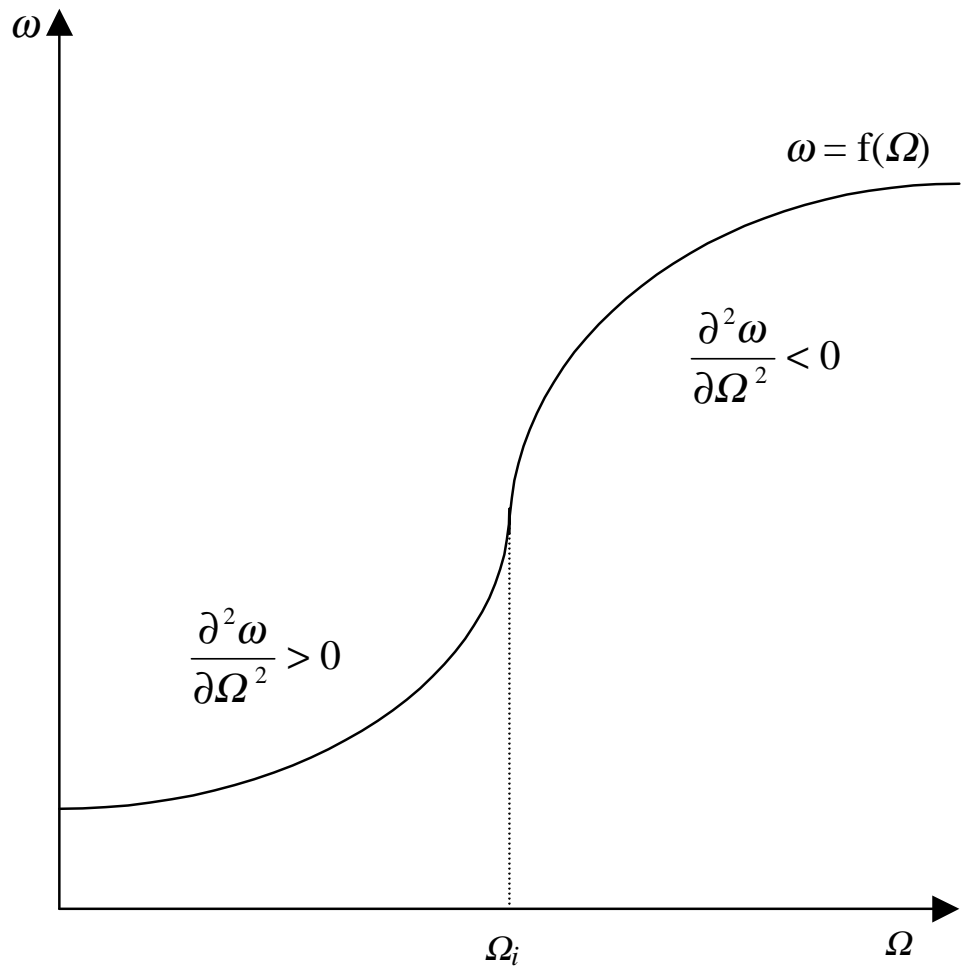

Figure 1: Reaction Function

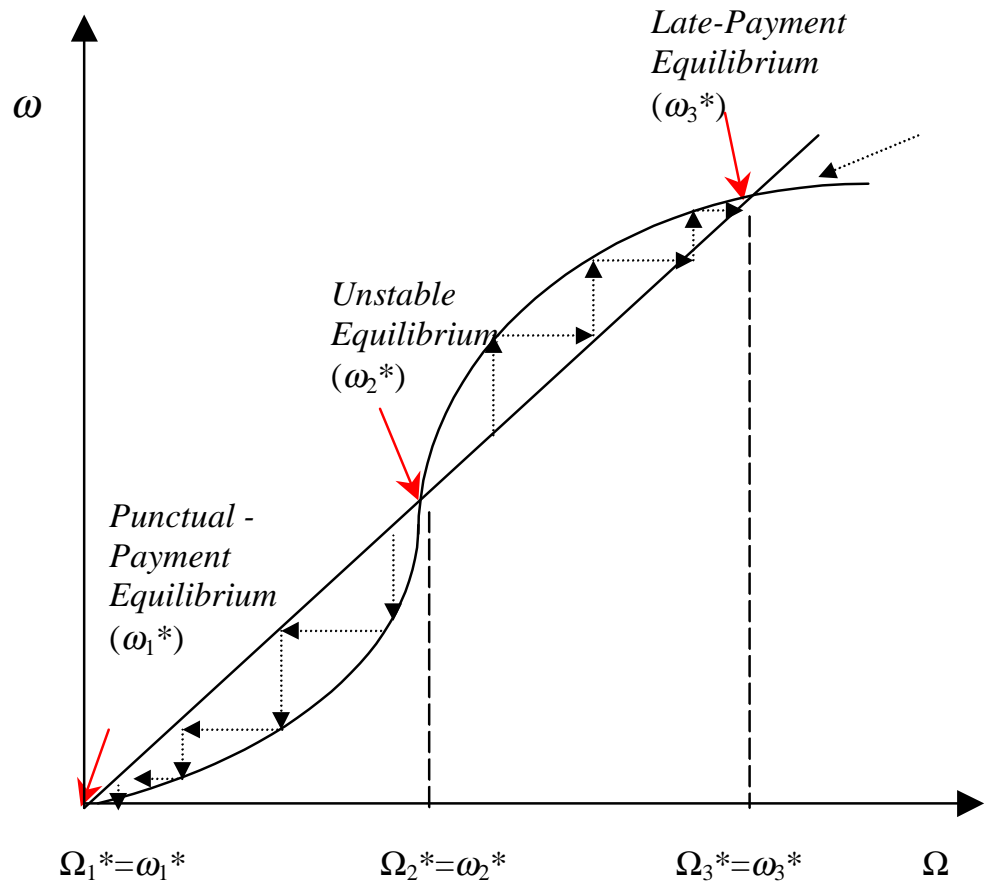

Figure 2: Symmetric Nash Equilibria 
Figure 3. Wage Arrears Equilibrium: Empirical Estimates, 1994-1998
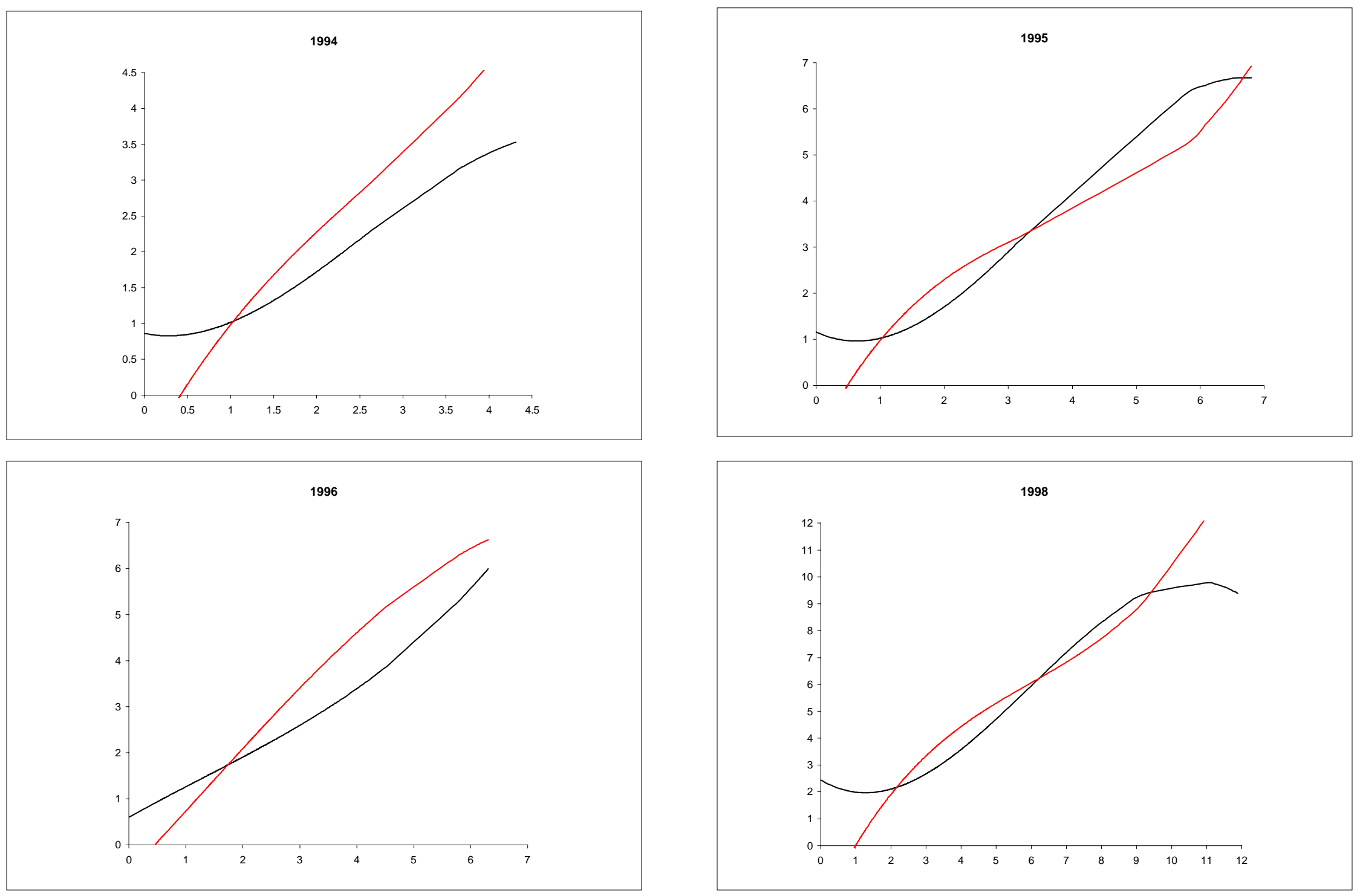


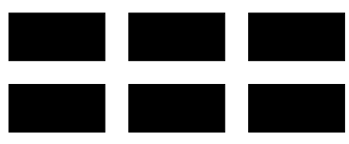

THE WILLIAM DAVIDSON INSTITUTE

AT THE UNIVERSITY OF MICHIGAN BUSINESSSCHOOL

\section{DAVIDSON INSTITUTE WORKING PAPER SERIES}

Working Papers are available at: www.wdi.bus.umich.edu

CURRENT AS OF 10/31//00

\begin{tabular}{|c|c|c|}
\hline Publication & Authors & Date \\
\hline $\begin{array}{l}\text { No. } 321 \text { Equilibrium Wage Arrears: A Theoretical and Empirical } \\
\text { Analysis of Institutional Lock-In }\end{array}$ & $\begin{array}{l}\text { John S. Earle and Klara Z. } \\
\text { Sabirianova }\end{array}$ & Oct. 2000 \\
\hline No. 320 Rethinking Marketing Programs for Emerging Markets & $\begin{array}{l}\text { Niraj Dawar and Amitava } \\
\text { Chattopadhyay }\end{array}$ & June 2000 \\
\hline $\begin{array}{l}\text { No. } 319 \text { Public Finance and Low Equilibria in Transition Economies; } \\
\text { the Role of Institutions }\end{array}$ & $\begin{array}{l}\text { Daniel Daianu and Radu } \\
\text { Vranceanu }\end{array}$ & June 2000 \\
\hline $\begin{array}{l}\text { No. } 318 \text { Some Econometric Evidence on the Effectiveness of Active } \\
\text { Labour Market Programmes in East Germany }\end{array}$ & $\begin{array}{l}\text { Martin Eichler and Michael } \\
\text { Lechner }\end{array}$ & June 2000 \\
\hline No. 317 A Model of Russia's "Virtual Economy" & R.E Ericson and B.W Ickes & May 2000 \\
\hline $\begin{array}{l}\text { No. } 316 \text { Financial Institutions, Financial Contagion, and Financial } \\
\text { Crises }\end{array}$ & $\begin{array}{l}\text { Haizhou Huang and Chenggang } \\
\mathrm{Xu}\end{array}$ & Mar. 2000 \\
\hline $\begin{array}{l}\text { No. } 315 \text { Privatization versus Regulation in Developing Economies: The } \\
\text { Case of West African Banks }\end{array}$ & $\begin{array}{l}\text { Jean Paul Azam, Bruno Biais, and } \\
\text { Magueye Dia }\end{array}$ & Feb. 2000 \\
\hline $\begin{array}{l}\text { No. } 314 \text { Is Life More Risky in the Open? Household Risk-Coping and } \\
\text { the Opening of China's Labor Markets }\end{array}$ & John Giles & Apr. 2000 \\
\hline $\begin{array}{l}\text { No. } 313 \text { Networks, Migration and Investment: Insiders and Outsiders in } \\
\text { Tirupur's Production Cluster }\end{array}$ & $\begin{array}{l}\text { Abhijit Banerjee and Kaivan } \\
\text { Munshi }\end{array}$ & Mar. 2000 \\
\hline $\begin{array}{l}\text { No. } 312 \text { Computational Analysis of the Impact on India of the Uruguay } \\
\text { Round and the Forthcoming WTO Trade Negotiations }\end{array}$ & $\begin{array}{l}\text { Rajesh Chadha, Drusilla K. } \\
\text { Brown, Alan V. Deardorff and } \\
\text { Robert M. Stern }\end{array}$ & Mar. 2000 \\
\hline No. 311 Subsidized Jobs for Unemployed Workers in Slovakia & Jan. C. van Ours & May 2000 \\
\hline No. 310 Determinants of Managerial Pay in the Czech Republic & $\begin{array}{l}\text { Tor Eriksson, Jaromir Gottvald } \\
\text { and Pavel Mrazek }\end{array}$ & May 2000 \\
\hline $\begin{array}{l}\text { No. } 309 \text { The Great Human Capital Reallocation: An Empirical Analysis } \\
\text { of Occupational Mobility in Transitional Russia }\end{array}$ & Klara Z. Sabirianova & Oct. 2000 \\
\hline No. 308 Economic Development, Legality, and the Transplant Effect & $\begin{array}{l}\text { Daniel Berkowitz, Katharina } \\
\text { Pistor, and Jean-Francois Richard }\end{array}$ & Feb. 2000 \\
\hline $\begin{array}{l}\text { No. } 307 \text { Community Participation, Teacher Effort, and Educational } \\
\text { Outcome: The Case of El Salvador's EDUCO Program }\end{array}$ & Yasuyuki Sawada & Nov. 1999 \\
\hline No. 306 Gender Wage Gap and Segregation in Late Transition & Stepan Jurajda & May 2000 \\
\hline $\begin{array}{l}\text { No. } 305 \text { The Gender Pay Gap in the Transition from Communism: } \\
\text { Some Empirical Evidence }\end{array}$ & Andrew Newell and Barry Reilly & May 2000 \\
\hline No. 304 Post-Unification Wage Growth in East Germany & Jennifer Hunt & Nov. 1998 \\
\hline $\begin{array}{l}\text { No. } 303 \text { How Does Privatization Affect Workers? The Case of the } \\
\text { Russian Mass Privatization Program }\end{array}$ & Elizabeth Brainerd & May 2000 \\
\hline $\begin{array}{l}\text { No. } 302 \text { Liability for Past Environmental Contamination and } \\
\text { Privatization }\end{array}$ & Dietrich Earnhart & Mar. 2000 \\
\hline No. 301 Varieties, Jobs and EU Enlargement & $\begin{array}{l}\text { Tito Boeri and Joaquim Oliveira } \\
\text { Martins }\end{array}$ & May 2000 \\
\hline No. 300 Employer Size Effects in Russia & Todd Idson & Apr. 2000 \\
\hline $\begin{array}{l}\text { No. } 299 \text { Information Complements, Substitutes, and Strategic Product } \\
\text { Design }\end{array}$ & $\begin{array}{l}\text { Geoffrey G. Parker and Marshall } \\
\text { W. Van Alstyne }\end{array}$ & Mar. 2000 \\
\hline $\begin{array}{l}\text { No. } 298 \text { Markets, Human Capital, and Inequality: Evidence from Rural } \\
\text { China }\end{array}$ & $\begin{array}{l}\text { Dwayne Benjamin, Loren Brandt, } \\
\text { Paul Glewwe, and Li Guo }\end{array}$ & May 2000 \\
\hline No. 297 Corporate Governance in the Asian Financial Crisis & $\begin{array}{l}\text { Simon Johnson, Peter Boone, } \\
\text { Alasdair Breach, and Eric } \\
\text { Friedman }\end{array}$ & Nov. 1999 \\
\hline
\end{tabular}




\begin{tabular}{|c|c|c|}
\hline No. 296 Competition and Firm Performance: Lessons from Russia & J. David Brown and John S. Earle & Mar. 2000 \\
\hline No. 295 Wage Determination in Russia: An Econometric Investigation & $\begin{array}{l}\text { Peter J. Luke and Mark E. } \\
\text { Schaffer }\end{array}$ & Mar. 2000 \\
\hline $\begin{array}{l}\text { No. 294: Can Banks Promote Enterprise Restructuring?: Evidence From } \\
\text { a Polish Bank's Experience }\end{array}$ & John P. Bonin and Bozena Leven & Mar. 2000 \\
\hline No. 293: Why do Governments Sell Privatised Companies Abroad? & $\begin{array}{l}\text { Bernardo Bortolotti, Marcella } \\
\text { Fantini and Carlo Scarpa }\end{array}$ & Mar. 2000 \\
\hline $\begin{array}{l}\text { No. 292: Going Public in Poland: Case-by-Case Privatizations, Mass } \\
\text { Privatization and Private Sector Initial Public Offerings }\end{array}$ & Wolfgang Aussenegg & Dec. 1999 \\
\hline $\begin{array}{l}\text { No. 291: Institutional Technology and the Chains of Trust: Capital } \\
\text { Markets and Privatization in Russia and the Czech Republic }\end{array}$ & Bruce Kogut and Andrew Spicer & Mar. 1999 \\
\hline No. 290: Banking Crises and Bank Rescues: The Effect of Reputation & Jenny Corbett and Janet Mitchell & Jan. 2000 \\
\hline $\begin{array}{l}\text { No. 289: Do Active Labor Market Policies Help Unemployed Workers } \\
\text { to Find and Keep Regular Jobs? }\end{array}$ & Jan C. van Ours & Feb. 2000 \\
\hline No. 288: Consumption Patterns of the New Elite in Zimbabwe & Russell Belk & Feb. 2000 \\
\hline $\begin{array}{l}\text { No. 287: Barter in Transition Economies: Competing Explanations } \\
\text { Confront Ukranian Data }\end{array}$ & $\begin{array}{l}\text { Dalia Marin, Daniel Kaufmann } \\
\text { and Bogdan Gorochowskij }\end{array}$ & Jan. 2000 \\
\hline $\begin{array}{l}\text { No. 286: The Quest for Pension Reform: Poland's Security through } \\
\text { Diversity }\end{array}$ & $\begin{array}{l}\text { Marek Góra and Michael } \\
\text { Rutkowski }\end{array}$ & Jan. 2000 \\
\hline No. 285: Disorganization and Financial Collapse & $\begin{array}{l}\text { Dalia Marin and Monika } \\
\text { Schnitzer }\end{array}$ & Oct. 1999 \\
\hline No. 284: Coordinating Changes in M-form and U-form Organizations & $\begin{array}{l}\text { Yingyi Qian, Gérard Roland and } \\
\text { Chenggang Xu }\end{array}$ & May 1999 \\
\hline $\begin{array}{l}\text { No. 283: Why Russian Workers Do Not Move: Attachment of Workers } \\
\text { Through In-Kind Payments }\end{array}$ & Guido Friebel and Sergei Guriev & Oct. 1999 \\
\hline No. 282: Lessons From Fiascos in Russian Corporate Governance & $\begin{array}{l}\text { Merritt B. Fox and Michael A. } \\
\text { Heller }\end{array}$ & Oct. 1999 \\
\hline $\begin{array}{l}\text { No. 281: Income Distribution and Price Controls: Targeting a Social } \\
\text { Safety Net During Economic Transition }\end{array}$ & $\begin{array}{l}\text { Michael Alexeev and James } \\
\text { Leitzel }\end{array}$ & Mar. 1999 \\
\hline $\begin{array}{l}\text { No. 280: Starting Positions, Reform Speed, and Economic Outcomes in } \\
\text { Transitioning Economies }\end{array}$ & William Hallagan and Zhang Jun & Jan. 2000 \\
\hline No. 279: The Value of Prominent Directors & $\begin{array}{l}\text { Yoshiro Miwa \& J. Mark } \\
\text { Ramseyer }\end{array}$ & Oct. 1999 \\
\hline No. 278: The System Paradigm & János Kornai & Apr. 1998 \\
\hline $\begin{array}{l}\text { No. 277: The Developmental Consequences of Foreign Direct } \\
\text { Investment in the Transition from Socialism to Capitalism: The } \\
\text { Performance of Foreign Owned Firms in Hungary }\end{array}$ & Lawrence Peter King & Sept. 1999 \\
\hline $\begin{array}{l}\text { No. 276: Stability and Disorder: An Evolutionary Analysis of Russia's } \\
\text { Virtual Economy }\end{array}$ & $\begin{array}{l}\text { Clifford Gaddy and Barry W. } \\
\text { Ickes }\end{array}$ & Nov. 1999 \\
\hline $\begin{array}{l}\text { No. 275: Limiting Government Predation Through Anonymous } \\
\text { Banking: A Theory with Evidence from China. }\end{array}$ & $\begin{array}{l}\text { Chong-En Bai, David D. Li, } \\
\text { Yingyi Qian and Yijiang Wang }\end{array}$ & July 1999 \\
\hline No. 274: Transition with Labour Supply & Tito Boeri & Dec. 1999 \\
\hline $\begin{array}{l}\text { No. 273: Sectoral Restructuring and Labor Mobility: A Comparative } \\
\text { Look at the Czech Republic }\end{array}$ & Vit Sorm and Katherine Terrell & Nov. 1999 \\
\hline $\begin{array}{l}\text { No. 272: Published in: Journal of Comparative Economics "Returns to } \\
\text { Human Capital Under the Communist Wage Grid and During the } \\
\text { Transition to a Market Economy" Vol. 27, pp. 33-60 } 1999 .\end{array}$ & $\begin{array}{l}\text { Daniel Munich, Jan Svejnar and } \\
\text { Katherine Terrell }\end{array}$ & Oct. 1999 \\
\hline $\begin{array}{l}\text { No. 271: Barter in Russia: Liquidity Shortage Versus Lack of } \\
\text { Restructuring }\end{array}$ & $\begin{array}{l}\text { Sophie Brana and Mathilde } \\
\text { Maurel }\end{array}$ & June 1999 \\
\hline $\begin{array}{l}\text { No. 270: Tests for Efficient Financial Intermediation with Application to } \\
\text { China }\end{array}$ & Albert Park and Kaja Sehrt & Mar. 1999 \\
\hline $\begin{array}{l}\text { No. 269a: Russian Privatization and Corporate Governance: What Went } \\
\text { Wrong? }\end{array}$ & $\begin{array}{l}\text { Bernard Black, Reinier Kraakman } \\
\text { and Anna Tarassova }\end{array}$ & May 2000 \\
\hline $\begin{array}{l}\text { No. 269: Russian Privatization and Corporate Governance: What Went } \\
\text { Wrong? }\end{array}$ & $\begin{array}{l}\text { Bernard Black, Reinier Kraakman } \\
\text { and Anna Tarassova }\end{array}$ & Sept. 1999 \\
\hline
\end{tabular}


Davidson Institute Working Papers are available at: www.wdi.bus.umich.edu

\begin{tabular}{|c|c|c|}
\hline No. 268: Are Russians Really Ready for Capitalism? & Susan Linz & Sept. 1999 \\
\hline No. 267: Do Stock Markets Promote Economic Growth? & $\begin{array}{l}\text { Randall K. Filer, Jan Hanousek } \\
\text { and Nauro Campos }\end{array}$ & Sept. 1999 \\
\hline $\begin{array}{l}\text { No. 266: Objectivity, Proximity and Adaptability in Corporate } \\
\text { Governance }\end{array}$ & $\begin{array}{l}\text { Arnoud W.A Boot and Jonathan } \\
\text { R. Macey }\end{array}$ & Sept. 1999 \\
\hline $\begin{array}{l}\text { No. 265: When the Future is not What it Used to Be: Lessons from the } \\
\text { Western European Experience to Forecasting Education and Training in } \\
\text { Transitional Economies }\end{array}$ & $\begin{array}{l}\text { Nauro F. Campos, Gerard } \\
\text { Hughes, Stepan Jurajda, and } \\
\text { Daniel Munich }\end{array}$ & Sept. 1999 \\
\hline $\begin{array}{l}\text { No. 264: The Institutional Foundation of Foreign-Invested Enterprises } \\
\text { (FIEs) in China }\end{array}$ & Yasheng Huang & Sept. 1999 \\
\hline $\begin{array}{l}\text { No. 263: The Changing Corporate Governance Paradigm: Implications } \\
\text { for Transition and Developing Countries }\end{array}$ & $\begin{array}{l}\text { Erik Berglof and Ernst-Ludwig } \\
\text { von Thadden }\end{array}$ & June 1999 \\
\hline No. 262: Law Enforcement and Transition & $\begin{array}{l}\text { Gerard Roland and Thierry } \\
\text { Verdier }\end{array}$ & May 1999 \\
\hline $\begin{array}{l}\text { No. 261: Soft Budget Constraints, Pecuniary Externality, and the Dual } \\
\text { Track System }\end{array}$ & Jiahua Che & June 2000 \\
\hline $\begin{array}{l}\text { No. 260: Missing Market in Labor Quality: The Role of Quality Markets } \\
\text { in Transition }\end{array}$ & Gary H. Jefferson & July 1999 \\
\hline $\begin{array}{l}\text { No. 259: Do Corporate Global Environmental Standards in Emerging } \\
\text { Markets Create or Destroy Market Value }\end{array}$ & $\begin{array}{l}\text { Glen Dowell, Stuart Hart and } \\
\text { Bernard Yeung }\end{array}$ & June 1999 \\
\hline No. 258: Public Training & k A. Puhani & June 1999 \\
\hline $\begin{array}{l}\text { No. 257: Ownership Versus Environment: Why are Public Sector Firms } \\
\text { Inefficient? }\end{array}$ & $\begin{array}{l}\text { P. Bartel and Ann E. } \\
\text { son }\end{array}$ & June 1999 \\
\hline $\begin{array}{l}\text { No. 256: Taxation and Evasion in the Presence of Exortion by } \\
\text { Organized Crime }\end{array}$ & $\begin{array}{l}\text { hael Alexeev, Eckhard Janeba } \\
\text { Stefan Osborne }\end{array}$ & Nov. 1999 \\
\hline No. 255: Revisiting Hungary's Bankruptcy Episode & $\begin{array}{l}\text { John P. Bonin and Mark E. } \\
\text { Schaffer }\end{array}$ & Sept. 1999 \\
\hline Markets: A Home-Country View & na v.N Whitman & June 1999 \\
\hline $\begin{array}{l}\text { No. 253: The Asian Financial Crisis: What Happened, and What is to be } \\
\text { Done }\end{array}$ & $\begin{array}{l}\text { Jeffrey D. Sachs and Wing Thye } \\
\text { Woo }\end{array}$ & Jan. 1999 \\
\hline No. 252: Organizational Law as Asset Partitioning & $\begin{array}{l}\text { Henry Hansmann and Reinier } \\
\text { Kraakman }\end{array}$ & Sept. 1999 \\
\hline $\begin{array}{l}\text { No. 251: Consumer Behavior Research in Emerging Consumer Markets: } \\
\text { the Case of the Optimum Stimulation Level in South Africa }\end{array}$ & $\begin{array}{l}\text { Jan-Benedict E. M. Steenkamp } \\
\text { and Steven M. Burgess }\end{array}$ & Sept. 1999 \\
\hline $\begin{array}{l}\text { No. 250: Property Rights Formation and the Organization of Exchange } \\
\text { and Production in Rural China }\end{array}$ & $\begin{array}{l}\text { Matthew A. Turner, Loren } \\
\text { Brandt, and Scott Rozelle }\end{array}$ & July 1998 \\
\hline $\begin{array}{l}\text { No. 249: Impacts of the Indonesian Economic Crisis: Price Changes and } \\
\text { the Poor }\end{array}$ & $\begin{array}{l}\text { James Levinsohn, Steven Berry, } \\
\text { and Jed Friedman }\end{array}$ & June 1999 \\
\hline $\begin{array}{l}\text { No. 248: Internal Barriers in the Transition of Enterprises from Central } \\
\text { Plan to Market }\end{array}$ & Charalambos Vlachoutsicos & July 1999 \\
\hline $\begin{array}{l}\text { No. 247: Spillovers from Multinationals in Developing Countries: the } \\
\text { Mechanisms at Work }\end{array}$ & Richard E. Caves & June 1999 \\
\hline $\begin{array}{l}\text { No. 246: Dynamism and Inertia on the Russian Labour Market: A } \\
\text { Model of Segmentation }\end{array}$ & $\begin{array}{l}\text { Irena Grosfeld, Claudia Senik- } \\
\text { Leygonie, Thierry Verdier, Stanislav } \\
\text { Kolenikov and Elena Paltseva }\end{array}$ & May 1999 \\
\hline No. 245: Lessons & \begin{tabular}{|l} 
John Bonin and Paul Wachtel \\
\end{tabular} & May 1999 \\
\hline $\begin{array}{l}\text { No. 244: Nominal-Real Tradeoffs and the Effects of Monetary Policy: } \\
\text { the Romanian Experience }\end{array}$ & Christian Popa & Dec. 1998 \\
\hline $\begin{array}{l}\text { No. 243: Privatization, Political Risk and Stock Market Development in } \\
\text { Emerging Economies }\end{array}$ & $\begin{array}{l}\text { Enrico C. Perotti and Pieter van } \\
\text { Oijen }\end{array}$ & Mar. 1999 \\
\hline No. 242: Investment Financing in Russian Financial-Industrial Groups & $\begin{array}{l}\text { Enrico C. Perotti and Stanislav } \\
\text { Gelfer }\end{array}$ & Oct. 1998 \\
\hline $\begin{array}{l}\text { No. 241: Can governments maintain hard budget constraints? Bank } \\
\text { lending and financial isolation in Romania }\end{array}$ & $\begin{array}{l}\text { Octavian Carare, Constantijn } \\
\text { Claessens, Enrico C. Perotti }\end{array}$ & Jan. 1999 \\
\hline $\begin{array}{l}\text { No. 240: Democratic Institutions and Economic Reform: the Polish } \\
\text { Case }\end{array}$ & $\begin{array}{l}\text { John E. Jackson, Jacek Klich, and } \\
\text { Krystyna Poznanska }\end{array}$ & Apr. 1998 \\
\hline
\end{tabular}


Davidson Institute Working Papers are available at: www.wdi.bus.umich.edu

\begin{tabular}{|c|c|c|}
\hline No. 239: A Longitudinal Study of IJV Performance in Eastern Europe & $\begin{array}{l}\text { Keith D. Brouthers and Gary } \\
\text { Bamossy }\end{array}$ & June 1999 \\
\hline $\begin{array}{l}\text { No. 238: Published in: Journal of Business Venturing, "Firm Creation } \\
\text { and Economic Transitions" } 14(5,6) \text { Sep/Nov 1999, pp. 427-450. }\end{array}$ & $\begin{array}{l}\text { John E. Jackson, Jacek Klich, } \\
\text { Krystyna Poznanska }\end{array}$ & July 1998 \\
\hline No. 237: Analysis of Entrepreneurial Attitudes in Poland & $\begin{array}{l}\text { John E. Jackson and Aleksander } \\
\text { S. Marcinkowski }\end{array}$ & Mar. 1997 \\
\hline $\begin{array}{l}\text { No. 236: Investment and Finance in De Novo Private Firms: Empirical } \\
\text { Results from the Czech Republic, Hungary, and Poland }\end{array}$ & $\begin{array}{l}\text { Andrzej Bratkowski, Irena } \\
\text { Grosfeld, Jacek Rostowski }\end{array}$ & Apr. 1999 \\
\hline $\begin{array}{l}\text { No. 235: Does a Soft Macroeconomic Environment Induce } \\
\text { Restructuring on the Microeconomic Level during the Transition } \\
\text { Period? Evidence from Investment Behavior of Czech Enterprises }\end{array}$ & Lubomír Lízal & June 1999 \\
\hline $\begin{array}{l}\text { No. 234: Banking Reform in China: Gradually Strengthening Pillar or } \\
\text { Fragile Reed? }\end{array}$ & John Bonin & June 1999 \\
\hline $\begin{array}{l}\text { No. 233: Theories of Soft Budget Constraints and the Analysis of } \\
\text { Banking Crises }\end{array}$ & Janet Mitchell & Mar. 1999 \\
\hline $\begin{array}{l}\text { No. 232: Unemployment Risk, Precautionary Savings, and } \\
\text { Moonlighting in Russia }\end{array}$ & $\begin{array}{l}\text { Alessandra Guariglia and Byung- } \\
\text { Yeon Kim }\end{array}$ & June 1999 \\
\hline $\begin{array}{l}\text { No. 231: Investing in Turbulent Times: The Investment Behavior of } \\
\text { Polish Firms in the Transition }\end{array}$ & $\begin{array}{l}\text { Josef C. Brada, Arthur E. King, } \\
\text { and Chia-Ying Ma }\end{array}$ & Apr. 1999 \\
\hline No. 230: The End of Moderate Inflation in Three Transition Economies? & Josef C. Brada and Ali M. Kutan & Apr. 1999 \\
\hline $\begin{array}{l}\text { No. 229: Back to the Future: The Growth Prospects of Transition } \\
\text { Economies Reconsidered }\end{array}$ & Nauro F. Campos & Apr. 1999 \\
\hline No. 228: The Enterprise Isolation Program in Russia & Simeon Djankov & Apr. 1999 \\
\hline $\begin{array}{l}\text { No. 227: Published in: Journal of Comparative Economics, "Ownership } \\
\text { Concentration and Corporate Performance in the Czech Republic" } \\
27(3) \text {, Sept. 1999, pp. 498-513. }\end{array}$ & $\begin{array}{l}\text { Stijn Claessens and Simeon } \\
\text { Djankov }\end{array}$ & Apr. 1999 \\
\hline $\begin{array}{l}\text { No. 226: Unemployment Benefit Entitlement and Training Effects in } \\
\text { Poland during Transition }\end{array}$ & Patrick A. Puhani & Mar. 1999 \\
\hline No. 225: Transition at Whirlpool-Tatramat: Case Studies & $\begin{array}{l}\text { Hans Brechbuhl and Sonia } \\
\text { Ferencikova }\end{array}$ & Mar. 1999 \\
\hline $\begin{array}{l}\text { No. 224: Measuring Progress in Transition and Towards EU Accession: } \\
\text { A Comparison of Manufacturing Firms in Poland, Romania, and Spain }\end{array}$ & $\begin{array}{l}\text { Wendy Carlin, Saul Estrin, and } \\
\text { Mark Schaffer }\end{array}$ & Mar. 1999 \\
\hline $\begin{array}{l}\text { No. 223: Product Market Competition in Transition Economies: } \\
\text { Increasing Varieties and Consumer Loyalty }\end{array}$ & Mitsutoshi M. Adachi & Mar. 1999 \\
\hline $\begin{array}{l}\text { No. 222: Opaque Markets and Rapid Growth: the Superiority of Bank- } \\
\text { Centered Financial Systems for Developing Nations }\end{array}$ & Rodney Wallace & July 1999 \\
\hline No. 221: Technology Spillovers through Foreign Direct Investment & Yuko Kinoshita & Jan. 1999 \\
\hline $\begin{array}{l}\text { No. 220: Managerial, Expertise and Team Centered Forms of } \\
\text { Organizing: A Cross-Cultural Exploration of Independence in } \\
\text { Engineering Work }\end{array}$ & Leslie Perlow & Jan. 1999 \\
\hline $\begin{array}{l}\text { No. 219: Household Structure and Labor Demand in Agriculture: } \\
\text { Testing for Separability in Rural China }\end{array}$ & $\begin{array}{l}\text { Audra J. Bowlus and Terry } \\
\text { Sicular }\end{array}$ & Jan. 1999 \\
\hline $\begin{array}{l}\text { No. 218: Competing Strategies of FDI and Technology Transfer to } \\
\text { China: American and Japanese Firms }\end{array}$ & $\begin{array}{l}\text { W. Mark Fruin and Penelope } \\
\text { Prime }\end{array}$ & Jan. 1999 \\
\hline $\begin{array}{l}\text { No. } 217 \text { Published in: Journal of Comparative Economics, "Returns to } \\
\text { Mobility in the Transition to a Market Economy" 27(1), Mar } 1999 .\end{array}$ & $\begin{array}{l}\text { Tito Boeri and Christopher J. } \\
\text { Flinn }\end{array}$ & Jan. 1999 \\
\hline $\begin{array}{l}\text { No. } 216 \text { Published in: Journal of Comparative Economics, "Labor } \\
\text { Market Policies and Unemployment in the Czech Republic." 27(1), Mar } \\
\text { 1999, pp. 33-60. }\end{array}$ & Katherine Terrell and Vit Sorm & Nov. 1998 \\
\hline $\begin{array}{l}\text { No. } 215 \text { Published in: Journal of Comparative Economics, "Active } \\
\text { Labor Market Policies in Poland: Human Capital Enhancement, } \\
\text { Stigmatization or Benefit Churning?" 27(1), Mar 1999, pp. 61- . }\end{array}$ & $\begin{array}{l}\text { Jochen Kluve, Hartmut Lehmann, } \\
\text { and Christoph M. Schmidt }\end{array}$ & Dec. 1998 \\
\hline $\begin{array}{l}\text { No. } 214 \text { Published in: Journal of Comparative Economics, "Does the } \\
\text { Slovenian Public Work Program Increase Participants' Chances to Find } \\
\text { a Job?" 27(1), Mar 1999, pp. 113- . }\end{array}$ & Milan Vodopivec & Dec. 1998 \\
\hline
\end{tabular}




\begin{tabular}{|c|c|c|}
\hline $\begin{array}{l}\text { No. } 213 \text { Published in: Journal of Comparative Economics, "Effects of } \\
\text { Active Labor Market Programs on the Transition Rate from } \\
\text { Unemployment into Regular Jobs in the Slovak Republic." 27(1), Mar } \\
\text { 1999, pp. 90-. }\end{array}$ & $\begin{array}{l}\text { Martina Lubyova and Jan C. van } \\
\text { Ours }\end{array}$ & Dec. 1998 \\
\hline $\begin{array}{l}\text { No. 212: The Marketing System in Bulgarian Livestock Production - } \\
\text { The Present State and Evolutionary Processes During the Period of } \\
\text { Economic Transition }\end{array}$ & Yordan Staykov, Team Leader & Oct. 1998 \\
\hline No. 211: Bankruptcy Experience in Hungary and the Czech Republic & Janet Mitchell & Oct. 1998 \\
\hline $\begin{array}{l}\text { No 210: Values, Optimum Stimulation Levels and Brand Loyalty: New } \\
\text { Scales in New Populations }\end{array}$ & $\begin{array}{l}\text { Steven M. Burgess and Mari } \\
\text { Harris }\end{array}$ & Sept. 1998 \\
\hline No. 209: Inherited Wealth, Corporate Control and Economic Growth & $\begin{array}{l}\text { Randall K. Morck, David A. } \\
\text { Stangeland, and Bernard Yeung }\end{array}$ & Sept. 1998 \\
\hline $\begin{array}{l}\text { No. 208: A Cultural Analysis of Homosocial Reproduction and } \\
\text { Contesting Claims to Competence in Transitional Firms }\end{array}$ & Michael D. Kennedy & July 1998 \\
\hline $\begin{array}{l}\text { No. 207: From Survival to Success: The Journey of Corporate } \\
\text { Transformation at Haier. Forthcoming in Managing Organizational } \\
\text { Change in Transition Economies ed. Daniel Denison. }\end{array}$ & $\begin{array}{l}\text { Arthur Yeung and Kenneth } \\
\text { DeWoskin }\end{array}$ & July 1998 \\
\hline $\begin{array}{l}\text { No. 206: Why Do People Work If They Are Not Paid? An Example } \\
\text { from Eastern Europe. Forthcoming in Managing Organizational Change } \\
\text { in Transition Economies. }\end{array}$ & Irina L. Zinovieva & May 1998 \\
\hline $\begin{array}{l}\text { No. 205: Firm Ownership and Work Motivation in Bulgaria and } \\
\text { Hungary: An Empirical Study of the Transition in the Mid-1990s. } \\
\text { Forthcoming in Managing Organizational Change in Transition } \\
\text { Economies ed. Daniel Denison. }\end{array}$ & $\begin{array}{l}\text { Robert A. Roe, Irina L. } \\
\text { Zinovieva, Elizabeth Dienes, and } \\
\text { Laurens A. ten Horn }\end{array}$ & May 1998 \\
\hline $\begin{array}{l}\text { No. 204: Human Resource Management in the Restructuring of Chinese } \\
\text { Joint Ventures. Forthcoming in Managing Organizational Change in } \\
\text { Transition Economies ed. Daniel Denison. }\end{array}$ & Nandani Lynton & Apr. 1998 \\
\hline $\begin{array}{l}\text { No. 203: Emergent Compensation Strategies in Post-Socialist Poland: } \\
\text { Understanding the Cognitive Underpinnings of Management Practices } \\
\text { in a Transition Economy. Forthcoming in Managing Organizational } \\
\text { Change in Transition Economies ed. Daniel Denison. }\end{array}$ & Marc Weinstein & Mar. 1998 \\
\hline $\begin{array}{l}\text { No. 202: Corporate Transformation and Organizational Learning: The } \\
\text { People's Republic of China. Forthcoming in Managing Organizational } \\
\text { Change in Transition Economies ed. Daniel Denison. }\end{array}$ & $\begin{array}{l}\text { Meinolf Dierkes and Zhang } \\
\text { Xinhua }\end{array}$ & Mar. 1998 \\
\hline $\begin{array}{l}\text { No. 201: Foreign Direct Investment as a Factor of Change: The Case of } \\
\text { Slovakia. Forthcoming in Managing Organizational Change in } \\
\text { Transition Economies ed. Daniel Denison. }\end{array}$ & Sonia Ferencikova & Feb. 1998 \\
\hline $\begin{array}{l}\text { No. 200: Radical versus Incremental Change: The Role of Capabilities, } \\
\text { Competition, and Leaders. Forthcoming in Managing Organizational } \\
\text { Change in Transition Economies ed. Daniel Denison. }\end{array}$ & Karen L. Newman & Feb. 1998 \\
\hline $\begin{array}{l}\text { No. 199: The Emergence of Market Practices in China's Economic } \\
\text { Transition: Price Setting Practices in Shanghai's Industrial Firms. } \\
\text { Forthcoming in Managing Organizational Change in Transition } \\
\text { Economies ed. Daniel Denison. }\end{array}$ & Douglas Guthrie & Feb. 1998 \\
\hline $\begin{array}{l}\text { No. 198: The Application of Change Management Methods at Business } \\
\text { Organizations Operating in Hungary: Challenges in the Business and } \\
\text { Cultural Environment and First Practical Experiences. Forthcoming in } \\
\text { Managing Organizational Change in Transition Economies ed. Daniel } \\
\text { Denison. }\end{array}$ & Dr. János Fehér & Jan. 1998 \\
\hline $\begin{array}{l}\text { No. 197: Organizational Changes in Russian Industrial Enterprises: } \\
\text { Mutation of Decision-Making Structures and Transformations of } \\
\text { Ownership. Forthcoming in Managing Organizational Change in } \\
\text { Transition Economies ed. Daniel Denison. }\end{array}$ & Igor B. Gurkov & Jan. 1998 \\
\hline $\begin{array}{l}\text { No. 196: Understanding and Managing Challenges to the Romanian } \\
\text { Companies during Transition. Forthcoming in Managing Organizational } \\
\text { Change in Transition Economies ed. Daniel Denison. }\end{array}$ & $\begin{array}{l}\text { Dan Candea and Rodica M. } \\
\text { Candea }\end{array}$ & Jan. 1998 \\
\hline
\end{tabular}


No. 195: Insider Lending and Economic Transition: The Structure,

Lisa A. Keister

Dec. 1997

Function, and Performance Impact of Finance Companies in Chinese

Business Groups. Forthcoming in Managing Organizational Change in

Transition Economies ed. Daniel Denison.

No. 194: Japanese Investment in Transitional Economies:

Characteristics and Performance. Forthcoming in Managing

Organizational Change in Transition Economies ed. Daniel Denison.

No. 193: Building Successful Companies in Transition Economies.

Forthcoming in Managing Organizational Change in Transition

Economies ed. Daniel Denison.

No. 192: Russian Communitariansim: An Invisible Fist in the

Transformation Process of Russia. Forthcoming in Managing

Organizational Change in Transition Economies ed. Daniel Denison.

No. 191: Teaching the Dinosaurs to Dance

No. 190: Strategic Restructuring: Making Capitalism in Post-

Communist Eastern Europe. Forthcoming in Managing Organizational

Change in Transition Economies ed. Daniel Denison.

No. 189: Published in: Regional Science and Urban Economics,

"Russia's Internal Border." 29(5), Sept. 1999.

No. 187: Corporate Structure and Performance in Hungary

No. 186: Performance of Czech Companies by Ownership Structure

No. 185: Firm Performance in Bulgaria and Estonia: The effects of competitive pressure, financial pressure and disorganisation

No. 184: Investment and Wages during the Transition: Evidence from Slovene Firms

No. 183: Investment Portfolio under Soft Budget: Implications for Growth, Volatility and Savings

No. 181: Delegation and Delay in Bank Privatization

No. 180: Financing Mechanisms and R\&D Investment

No. 179: Organizational Culture and Effectiveness: The Case of Foreign

Firms in Russia

No. 178: Output and Unemployment Dynamics in Transition

No. 177: Published in: Economics of Transition, "Bureaucracies in the

Russian Voucher Privatization.” 8(1), 2000, pp. 37-57.

No. 176: Chronic Moderate Inflation in Transition: The Tale of Hungary

No. 175: Privatisation and Market Structure in a Transition Economy

No. 174: Ownership and Managerial Competition: Employee, Customer,

or Outside Ownership

No. 173: Intragovernment Procurement of Local Public Good: A

Theory of Decentralization in Nondemocratic Government

No. 172: Political Instability and Growth in Proprietary Economies

No. 171: Published in Post-Communist Economies, "Framework Issues

in the Privatization Strategies of the Czech Republic, Hungary, and

Poland" 11(1) Mar. 1999.

No. 170: Published in: European Journal of Political Economy

"Privatization, Ownership Structure and Transparency: How to Measure

a Real Involvement of the State" 15(4), Nov. 1999, pp. 605-18.

No. 169 Published in: American Economic Review, "Unemployment and the Social Safety Net during Transitions to a Market Economy:

Evidence from Czech and Slovak Men” 88(5), Dec 1998, pp. 1117-1142

Paul W. Beamish and Andrew

Delios

Dr. Ivan Perlaki

Dr.

Charalambos Vlachoutsicos

Michal Cakrt

Lawrence P. King

Sept. 1997

Sept. 1997

Daniel Berkowitz and David N.

DeJong

László Halpern and Gábor Kórsöi

Andrew Weiss and Georgiy

Nikitin

\begin{tabular}{|l|l|}
\hline Jozef Konings & July 1998
\end{tabular}

Janez Prasnikar and Jan Svejnar

July 1998

Chongen Bai and Yijiang Wang

July 1998

Loránd Ambrus-Lakatos and

Ulrich Hege

Haizhou Huang and Chenggang

$\mathrm{Xu}$

Carl F. Fey and Daniel R.

Denison

Vivek H. Dehejia and Douglas W. Jan. 1998

Dwyer

\begin{tabular}{|l|l|}
\hline Guido Friebel & June 1998 \\
\hline
\end{tabular}

János Vincze

June 1998

John Bennett and James Maw

June 1998

Patrick Bolton and Chenggang

$\mathrm{Xu}$

\begin{tabular}{|l|l}
\hline Chong-en Bai, Yu Pan and & June 1998
\end{tabular}

Yijiang Wang

Jody Overland and Michael

Spagat

Morris Bornstein

Aug. 1998

Fran

Frantisek Turnovec

John C. Ham, Jan Svejnar, and

Katherine Terrell
May 1998

Dec. 1998

June 1998

\begin{tabular}{|l|}
\hline May 1998 \\
\hline Dec. 1998
\end{tabular}


Davidson Institute Working Papers are available at: www.wdi.bus.umich.edu

\begin{tabular}{|c|c|c|}
\hline $\begin{array}{l}\text { No. 167: Voucher Privatization with Investment Funds: An Institutional } \\
\text { Analysis }\end{array}$ & David Ellerman & Mar. 1998 \\
\hline $\begin{array}{l}\text { No. 166: Published in: Marketing Issues in Transitional Economies, } \\
\text { "Value Priorities and Consumer Behavior in a Transitional Economy: } \\
\text { The Case of South Africa" ed. Rajeev Batra. }\end{array}$ & $\begin{array}{l}\text { Steven M. Burgess and Jan- } \\
\text { Benedict E.M. Steenkamp }\end{array}$ & Aug. 1998 \\
\hline $\begin{array}{l}\text { No. 164: Finance and Investment in Transition: Czech Enterprises, } \\
\text { 1993-1994 }\end{array}$ & $\begin{array}{l}\text { Ronald Anderson and Chantal } \\
\text { Kegels }\end{array}$ & Sept. 1997 \\
\hline $\begin{array}{l}\text { No. 163: European Union Trade and Investment Flows U-Shaping } \\
\text { Industrial Output in Central and Eastern Europe: Theory and Evidence }\end{array}$ & $\begin{array}{l}\text { Alexander Repkine and Patrick P. } \\
\text { Walsh }\end{array}$ & Apr. 1998 \\
\hline $\begin{array}{l}\text { No. 162: Skill Acquisition and Private Firm Creation in Transition } \\
\text { Economies }\end{array}$ & Zuzana Brixiova and Wenli Li & Oct. 1999 \\
\hline No. 161: Corruption in Transition & Susanto Basu and David D. Li & May 1998 \\
\hline $\begin{array}{l}\text { No. 160a: Tenures that Shook the World: Worker Turnover in Russia, } \\
\text { Poland and Britain }\end{array}$ & $\begin{array}{l}\text { Hartmut Lehmann and Jonathan } \\
\text { Wadsworth }\end{array}$ & Nov. 1999 \\
\hline $\begin{array}{l}\text { No. 160: Tenures that Shook the World: Worker Turnover in the } \\
\text { Russian Federation and Poland }\end{array}$ & $\begin{array}{l}\text { Hartmut Lehmann and Jonathan } \\
\text { Wadsworth }\end{array}$ & June 1998 \\
\hline No. 159: Does Market Structure Matter? New Evidence from Russia & $\begin{array}{l}\text { Annette N. Brown and J. David } \\
\text { Brown }\end{array}$ & June 1998 \\
\hline $\begin{array}{l}\text { No. 158: Structural Adjustment and Regional Long Term } \\
\text { Unemployment in Poland }\end{array}$ & $\begin{array}{l}\text { Hartmut Lehmann and Patrick P. } \\
\text { Walsh }\end{array}$ & June 1997 \\
\hline $\begin{array}{l}\text { No. 157: Baby Boom or Bust? Changing Fertility in Post-Communist } \\
\text { Czech Republic and Slovakia }\end{array}$ & Robert S. Chase & Apr. 1998 \\
\hline $\begin{array}{l}\text { No. } 156 \text { Published in: Leadership and Organization Development } \\
\text { Journal, "Leading Radical Change in Transition Economies." Vol. 19, } \\
\text { No. 6, 1998, pp. 309-324. }\end{array}$ & Karen L. Newman & June 1998 \\
\hline $\begin{array}{l}\text { No. } 155 \text { Published in: Oxford Review of Economic Policy, "From } \\
\text { Theory into Practice? Restructuring and Dynamism in Transition } \\
\text { Economies." Vol. 13, No. 2, Summer 1997, pp. 77-105. }\end{array}$ & $\begin{array}{l}\text { Wendy Carlin and Michael } \\
\text { Landesmann }\end{array}$ & June 1997 \\
\hline $\begin{array}{l}\text { No. 154: The Model and the Reality: Assessment of Vietnamese SOE } \\
\text { Reform-Implementation at the Firm Level }\end{array}$ & $\begin{array}{l}\text { Edmund Malesky, Vu Thanh } \\
\text { Hung, Vu Thi Dieu Anh, and } \\
\text { Nancy K. Napier }\end{array}$ & July 1998 \\
\hline $\begin{array}{l}\text { No. } 153 \text { Published in: Journal of Comparative Economics, "Causes of } \\
\text { the Soft Budget Constraint: Evidence on Three Explanations." Vol. 26, } \\
\text { No. 1, Mar. 1998, pp. 104-116. }\end{array}$ & David D. Li and Minsong Liang & Mar. 1998 \\
\hline $\begin{array}{l}\text { No. } 152 \text { Published in: Comparative Economic Studies, "Enterprise } \\
\text { Restructuring in Russia's Transition Economy: Formal and Informal } \\
\text { Mechanisms." Vol. 40, No. 2, Summer 1998, pp. 5-52. }\end{array}$ & Susan J. Linz and Gary Krueger & Apr. 1998 \\
\hline $\begin{array}{l}\text { No. 151: Labor Productivity in Transition: A Regional Analysis of } \\
\text { Russian Industry }\end{array}$ & Susan J. Linz & May 1998 \\
\hline $\begin{array}{l}\text { No. 150: Tax Avoidance and the Allocation of Credit. Forthcoming in } \\
\text { Financial Systems in Transition: The Design of Financial Systems in } \\
\text { Central Europe eds. Anna Meyendorff and Anjan Thakor. }\end{array}$ & Anna Meyendorff & June 1998 \\
\hline $\begin{array}{l}\text { No. 149: Commitment, Versatility and Balance: Determinants of Work } \\
\text { Time Standards and Norms in a Multi-Country Study of Software } \\
\text { Engineers }\end{array}$ & Leslie Perlow and Ron Fortgang & Apr. 1998 \\
\hline $\begin{array}{l}\text { No. 148: Changes in Poland's Transfer Payments in the 1990s: the Fate } \\
\text { of Pensioners }\end{array}$ & Bozena Leven & June 1998 \\
\hline $\begin{array}{l}\text { No. 147: Environmental Protection and Economic Development: The } \\
\text { Case of the Huaihe River Basin Cleanup Plan }\end{array}$ & $\begin{array}{l}\text { Robert Letovsky, Reze Ramazani, } \\
\text { and Debra Murphy }\end{array}$ & June 1998 \\
\hline $\begin{array}{l}\text { No. 146: Chief Executive Compensation During Early Transition: } \\
\text { Further Evidence from Bulgaria }\end{array}$ & $\begin{array}{l}\text { Derek C. Jones, Takao Kato, and } \\
\text { Jeffrey Miller }\end{array}$ & June 1998 \\
\hline $\begin{array}{l}\text { No. } 145 \text { Published in: Economics of Transition, "Women's } \\
\text { Unemployment During the Transition: Evidence from Czech and Slovak } \\
\text { Micro Data," Vol. 7, No. 1, May 1999, pp. 47-78. }\end{array}$ & $\begin{array}{l}\text { John Ham, Jan Svejnar, and } \\
\text { Katherine Terrell }\end{array}$ & May 1998 \\
\hline No. 144: Investment and Wages in Slovenia & Janez Prasnikar & May 1998 \\
\hline
\end{tabular}




\begin{tabular}{|c|c|c|}
\hline $\begin{array}{l}\text { No. } 143 \text { Published in: Review of Financial Studies, "Optimal } \\
\text { Bankruptcy Laws Across Different Economic Systems," 12(2), 47-77, } \\
\text { Summer } 19993 .\end{array}$ & $\begin{array}{l}\text { Elazar Berkovitch and Ronen } \\
\text { Israel }\end{array}$ & Mar. 1998 \\
\hline $\begin{array}{l}\text { No. 142: Industrial Policy and Poverty in Transition Economies: Two } \\
\text { Steps Forward or One Step Back? }\end{array}$ & Susan J. Linz & Mar. 1998 \\
\hline $\begin{array}{l}\text { No. } 141 \text { Collective Ownership and Privatization of China's Village } \\
\text { Enterprises }\end{array}$ & Suwen Pan and Albert Park & Apr. 1998 \\
\hline $\begin{array}{l}\text { No. } 140 \text { A Comparative Look at Labor Mobility in the Czech Republic: } \\
\text { Where have all the Workers Gone? }\end{array}$ & Vit Sorm and Katherine Terrell & Apr. 1999 \\
\hline $\begin{array}{l}\text { No. } 139 \text { The Failure of the Government-Led Program of Corporate } \\
\text { Reorganization in Romania }\end{array}$ & $\begin{array}{l}\text { Simeon Djankov and Kosali } \\
\text { Ilayperuma }\end{array}$ & Sept. 1997 \\
\hline No. 138 Ownership and Employment in Russian Industry: 1992-1995 & Susan J. Linz & Mar. 1998 \\
\hline $\begin{array}{l}\text { No. } 137 \text { Published in: Journal of Political Economy, "Reform Without } \\
\text { Losers: An Interpretation of China's Dual-Track Approach to } \\
\text { Transition," Feb. 2000; Vol. 108, Iss.1; pg. } 120\end{array}$ & $\begin{array}{l}\text { Lawrence J. Lau, Yingyi Qian, } \\
\text { and Gerard Roland }\end{array}$ & Nov. 1997 \\
\hline $\begin{array}{l}\text { No. } 136 \text { Published in: European Economic Review, "The Political } \\
\text { Economy of Mass Privatization and the Risk of Expropriation," 44(2), } \\
\text { Feb. 2000, pgs. 393-421 }\end{array}$ & Klaus M. Schmidt & Mar. 1998 \\
\hline $\begin{array}{l}\text { No. 135: Radical Organizational Change: The Role of Starting } \\
\text { Conditions, Competition, and Leaders }\end{array}$ & Karen L. Newman & Jan. 1998 \\
\hline $\begin{array}{l}\text { No. 134: To Restructure or Not to Restructure: Informal Activities and } \\
\text { Enterprise Behavior in Transition }\end{array}$ & $\begin{array}{l}\text { Clifford Gaddy and Barry W. } \\
\text { Ickes }\end{array}$ & May 1998 \\
\hline No. 133: Management 101: Behavior of Firms in Transition Economies & Josef C. Brada & Mar. 1998 \\
\hline $\begin{array}{l}\text { No. } 132 \text { Published in: Quarterly Journal of Economics, "Interfirm } \\
\text { Relationships and Informal Credit in Vietnam," 114(4), Nov. 1999, pgs. } \\
\text { 1285-1320 }\end{array}$ & $\begin{array}{l}\text { John McMillan and Christopher } \\
\text { Woodruff }\end{array}$ & Feb. 1998 \\
\hline $\begin{array}{l}\text { No. } 131 \text { Published in: Comparative Economic Studies, "Will } \\
\text { Restructuring Hungarian Companies Innovate? An Investigation Based } \\
\text { on Joseph Berliner's Analysis of Innovation in Soviet Industry." Vol. } \\
\text { 40, No. 2, Summer 1998, pp. 53-74. }\end{array}$ & John B. Bonin and Istvan Abel & Mar. 1998 \\
\hline $\begin{array}{l}\text { No. 130: Published in The American Economic Review, "Changing } \\
\text { Incentives of the Chinese Bureaucracy." May, } 1998 .\end{array}$ & David D. Li & Jan. 1998 \\
\hline $\begin{array}{l}\text { No. 129: Restructuring Investment in Transition: A Model of the } \\
\text { Enterprise Decision }\end{array}$ & Richard E. Ericson & Jan. 1998 \\
\hline $\begin{array}{l}\text { No. } 128 \text { Published in: Comparative Economic Studies, "Job Rights in } \\
\text { Russian Firms: Endangered or Extinct Institutions?" Vol. 40, No. 4, } \\
\text { Winter 1998, pp. 1-32. }\end{array}$ & Susan J. Linz & Jan. 1998 \\
\hline No. 127: Accounting for Growth in Post-Soviet Russia & $\begin{array}{l}\text { Daniel Berkowitz and David N. } \\
\text { DeJong }\end{array}$ & Jan. 1998 \\
\hline $\begin{array}{l}\text { No. } 126 \text { Published in: Economics of Transition, "From Federalism, } \\
\text { Chinese Style, to Privatization Chinese Style," } 7(1), 1999 \text {, pgs. 103-31 }\end{array}$ & $\begin{array}{l}\text { Yuanzheng Cao, Yingyi Qian, } \\
\text { and Barry R. Weingast }\end{array}$ & Dec. 1997 \\
\hline $\begin{array}{l}\text { No. 125: Market Discipline in Conglomerate Banks: Is an Internal } \\
\text { Allocation of Cost of Capital Necessary as Incentive Device? } \\
\text { Forthcoming in Financial Systems in Transition: The Design of } \\
\text { Financial Systems in Central Europe eds. Anna Meyendorff and Anjan } \\
\text { Thakor. }\end{array}$ & $\begin{array}{l}\text { Arnoud W. A. Boot and Anjolein } \\
\text { Schmeits }\end{array}$ & Nov. 1997 \\
\hline $\begin{array}{l}\text { No. 124: Financial Discipline in the Enterprise Sector in Transition } \\
\text { Countries: How Does China Compare? }\end{array}$ & $\begin{array}{l}\text { Shumei Gao and Mark E. } \\
\text { Schaffer }\end{array}$ & Feb. 1998 \\
\hline $\begin{array}{l}\text { No. 123: Considerations of an Emerging Marketplace: Managers' } \\
\text { Perceptions in the Southern African Economic Community }\end{array}$ & Brent Chrite and David Hudson & Feb. 1998 \\
\hline No. 122: A Model of the Informal Economy in Transition Economies & $\begin{array}{l}\text { Simon Commander and Andrei } \\
\text { Tolstopiatenko }\end{array}$ & Nov. 1997 \\
\hline $\begin{array}{l}\text { No. 121: Local Labour Market Dynamics in the Czech and Slovak } \\
\text { Republics }\end{array}$ & $\begin{array}{l}\text { Peter Huber and Andreas } \\
\text { Worgotter }\end{array}$ & Nov. 1997 \\
\hline $\begin{array}{l}\text { No. 119: Institutional Upheaval and Company Transformation in } \\
\text { Emerging Market Economies }\end{array}$ & Karen L. Newman & Mar. 1998 \\
\hline
\end{tabular}




\begin{tabular}{|c|c|c|}
\hline No. 118: Industrial Decline and Labor Reallocation in Romania & John S. Earle & Oct. 1997 \\
\hline No. 117: Notes for an Essay on the Soft Budget Constraint & Lorand Ambrus-Lakatos & Jan. 1997 \\
\hline No. 116: Labor Demand During Transition in Hungary & Gabor Korosi & Oct. 1997 \\
\hline No. 115: Enterprise Performance and Managers' Profiles & $\begin{array}{l}\text { Simeon Djankov and Stijn } \\
\text { Claessens }\end{array}$ & Dec. 1997 \\
\hline $\begin{array}{l}\text { No. 114b Employment and Wages in Enterprises under Communism } \\
\text { and in Transition: Evidence From Central Europe and Russia }\end{array}$ & $\begin{array}{l}\text { Swati Basu, Saul Estrin, and Jan } \\
\text { Svejnar }\end{array}$ & Apr. 2000 \\
\hline $\begin{array}{l}\text { No. 114: Employment and Wage Behavior of Enterprises in Transitional } \\
\text { Economies }\end{array}$ & $\begin{array}{l}\text { Swati Basu, Saul Estrin, and Jan } \\
\text { Svejnar }\end{array}$ & Oct. 1997 \\
\hline $\begin{array}{l}\text { No. 113: Preliminary Evidence on Active Labor Programs' Impact in } \\
\text { Hungary and Poland }\end{array}$ & Christopher J. O’Leary & Oct. 1997 \\
\hline $\begin{array}{l}\text { No. 111: Unemployment Benefits and Incentives in Hungary: New } \\
\text { Evidence }\end{array}$ & Joachim Wolff & Oct. 1997 \\
\hline $\begin{array}{l}\text { No. 110: Published in: Empirical Economics, "Long-Term } \\
\text { Unemployment, Unemployment Benefits and Social Assistance: The } \\
\text { Polish Experience" Empirical-Economics; 23(1-2), 1998, pp. 55-85. }\end{array}$ & $\begin{array}{l}\text { Marek Gora and Christoph M. } \\
\text { Schmidt }\end{array}$ & Apr. 1997 \\
\hline $\begin{array}{l}\text { No. } 109 \text { Published in: Industrial and Labor Relations Review, "Markets } \\
\text { for Communist Human Capital: Returns to Education and Experience in } \\
\text { Post-Communist Czech Republic and Slovakia." 51(3), Apr. 1998, pp. } \\
\text { 401-423. }\end{array}$ & Robert S. Chase & Oct. 1997 \\
\hline $\begin{array}{l}\text { No. 107: The Worker-Firm Matching in the Transition: (Why) Are the } \\
\text { Czechs More Successful Than Others? }\end{array}$ & $\begin{array}{l}\text { Daniel Münich, Jan Svejnar, and } \\
\text { Katherine Terrell }\end{array}$ & Oct. 1997 \\
\hline $\begin{array}{l}\text { No. } 106 \text { Published in: Journal of Comparative Economics, "Job } \\
\text { Creation, Job Destruction and Growth of Newly Established, Privatized } \\
\text { and State-Owned Enterprises in Transition Economies: Survey Evidence } \\
\text { from Bulgaria, Hungary, and Romania," 26(3), Sept. 1998, pp. 429-445. }\end{array}$ & $\begin{array}{l}\text { Valentijn Bilsen and Jozef } \\
\text { Konings }\end{array}$ & Sept. 1998 \\
\hline $\begin{array}{l}\text { No. 105: Getting Behind the East-West [German] Wage Differential: } \\
\text { Theory and Evidence }\end{array}$ & $\begin{array}{l}\text { Michael Burda and Christoph } \\
\text { Schmidt }\end{array}$ & May 1997 \\
\hline No. 104: The Birth of the "Wage Curve" in Hungary, 1989-95 & Gabor Kertesi and Janos Kollo & Oct. 1997 \\
\hline $\begin{array}{l}\text { No. 103: Published in: Journal of Comparative Economics, "Grime and } \\
\text { Punishment: Job Insecurity and Wage Arrears in the Russian } \\
\text { Federation" 27, 595-617 (1999). }\end{array}$ & $\begin{array}{l}\text { Hartmut Lehmann, Jonathan } \\
\text { Wadsworth, and Alessandro } \\
\text { Acquisti }\end{array}$ & Oct. 1997 \\
\hline No. 102: Social Networks in Transition & $\begin{array}{l}\text { Lorena Barberia, Simon Johnson, } \\
\text { and Daniel Kaufmann }\end{array}$ & Oct. 1997 \\
\hline $\begin{array}{l}\text { No. 101: Depreciation and Russian Corporate Finance: A Pragmatic } \\
\text { Approach to Surviving the Transition }\end{array}$ & Susan J. Linz & Nov. 1997 \\
\hline No. 100: Romanian Financial System Reform & $\begin{array}{l}\text { Anna Meyendorff and Anjan V. } \\
\text { Thakor }\end{array}$ & Nov. 1997 \\
\hline $\begin{array}{l}\text { No. 99: Proceedings of the Conference on Strategic Alliances in } \\
\text { Transitional Economies, held May 20, } 1997 \text { at the Davidson Institute }\end{array}$ & Edited by Cynthia Koch & May 1997 \\
\hline No. 98: Institutions, Strain and the Underground Economy & Daniel Daianu and Lucian Albu & Nov. 1997 \\
\hline No. 97: Structure and Strain in Explaining Inter-Enterprise Arrears & Daniel Daianu & Nov. 1997 \\
\hline $\begin{array}{l}\text { No. 96: Resource Misallocation and Strain: Explaining Shocks in Post- } \\
\text { Command Economies }\end{array}$ & Daniel Daianu & Nov. 1997 \\
\hline $\begin{array}{l}\text { No. 95: Published in: Finance-a-Uver, "Czech Money Market: Emerging } \\
\text { Links Among Interest Rates." 48(2) } 1998 \text { pp. 99-109. }\end{array}$ & $\begin{array}{l}\text { Jan Hanousek and Evzen } \\
\text { Kocenda }\end{array}$ & Nov. 1997 \\
\hline $\begin{array}{l}\text { No. 94: Pre-Reform Industry and the } \\
\text { State Monopsony in China }\end{array}$ & $\begin{array}{l}\text { Xiao-Yuan Dong and Louis } \\
\text { Putterman }\end{array}$ & Oct. 1997 \\
\hline $\begin{array}{l}\text { No. 93: China's State-Owned Enterprises } \\
\text { In the First Reform Decade: } \\
\text { An Analysis of a Declining Monopsony }\end{array}$ & $\begin{array}{l}\text { Xiao-Yuan Dong and Louis } \\
\text { Putterman }\end{array}$ & Oct. 1997 \\
\hline No. 92: Expatriate Management in the Czech Republic & Richard B. Peterson & Sept. 1997 \\
\hline No. 91: China and the Idea of Economic Reform & Thomas G. Rawski & Apr. 1997 \\
\hline $\begin{array}{l}\text { No. } 90 \text { Published in: China Economic Review, "China's State Enterprise } \\
\text { Reform: An Overseas Perspective.” Vol. 8, Spring 1997, pp. 89-98. }\end{array}$ & Thomas G. Rawski & July 1997 \\
\hline
\end{tabular}




\begin{tabular}{|c|c|c|}
\hline $\begin{array}{l}\text { No. 89: The Economic Determinants of Internal Migration Flows in } \\
\text { Russia During Transition }\end{array}$ & Annette N. Brown & July 1997 \\
\hline $\begin{array}{l}\text { No. 88: Gender Wage Gaps in China's Labor Market: Size, Structure, } \\
\text { Trends }\end{array}$ & $\begin{array}{l}\text { Margaret Maurer-Fazio, Thomas } \\
\text { G. Rawski, and Wei Zhang }\end{array}$ & July 1997 \\
\hline No. 87: Privatisation in Central and Eastern Europe & Saul Estrin & June 1997 \\
\hline $\begin{array}{l}\text { No. 86: Published in : Economics of Transition, "The Effect of } \\
\text { Privatization on Wealth Distribution in Russia." v. 7, no. 2, 1999, pp. } \\
449-65\end{array}$ & Michael Alexeev & Feb. 1998 \\
\hline $\begin{array}{l}\text { No. 85: Was Privatization in Eastern Germany a Special Case? Some } \\
\text { Lessons from the Treuhand }\end{array}$ & Uwe Siegmund & Sept. 1997 \\
\hline No. 84: Start-ups and Transition & $\begin{array}{l}\text { Daniel M. Berkowitz and David J. } \\
\text { Cooper }\end{array}$ & Sept. 1997 \\
\hline $\begin{array}{l}\text { No. 83: Which Enterprises (Believe They) Have Soft Budgets after } \\
\text { Mass Privatization? Evidence from Mongolia }\end{array}$ & $\begin{array}{l}\text { James Anderson, Georges } \\
\text { Korsun, and Peter Murrell }\end{array}$ & Oct. 1997 \\
\hline $\begin{array}{l}\text { No. 82: Published in: European Economic Review, "Unemployment } \\
\text { Dynamics and the Restructuring of the Slovak Unemployment Benefit } \\
\text { System." Apr., } 1997 \text {. }\end{array}$ & $\begin{array}{l}\text { Martina Lubyova and Jan C. van } \\
\text { Ours }\end{array}$ & June 1997 \\
\hline No. 81: Determinants of Unemployment Duration in Russia & Mark C. Foley & Aug. 1997 \\
\hline No. 80: The Many Faces of Information Disclosure & $\begin{array}{l}\text { Arnoud W.A. Boot and Anjan V. } \\
\text { Thakor }\end{array}$ & Oct. 1997 \\
\hline $\begin{array}{l}\text { No. 79: Published in: Journal of Finance, "Foreign Speculators and } \\
\text { Emerging Equity Markets."v.22, iss. 2, 2000, pp. 565-613 }\end{array}$ & $\begin{array}{l}\text { Geert Bekaert and Campbell R. } \\
\text { Harvey }\end{array}$ & Aug. 1997 \\
\hline $\begin{array}{l}\text { No. 78: The Relationship Between Economic Factors and Equity } \\
\text { Markets in Central Europe }\end{array}$ & $\begin{array}{l}\text { Jan Hanousek and Randall K. } \\
\text { Filer }\end{array}$ & June 1997 \\
\hline $\begin{array}{l}\text { No. } 77 \text { Published in: Economics of Transition, "A Gini Decomposition } \\
\text { Analysis of Inequality in the Czech and Slovak Republics During the } \\
\text { Transition," Vol. 6, No.1, May 1998, pp. 23-46. }\end{array}$ & $\begin{array}{l}\text { Thesia I. Garner and Katherine } \\
\text { Terrell }\end{array}$ & May 1998 \\
\hline $\begin{array}{l}\text { No. 76: China's Emerging Market for Property Rights: Theoretical and } \\
\text { Empirical Perspectives }\end{array}$ & $\begin{array}{l}\text { Gary H. Jefferson and Thomas G. } \\
\text { Rawski }\end{array}$ & June 1997 \\
\hline $\begin{array}{l}\text { No. 75b: Test of Permanent Income Hypothesis on Czech Voucher } \\
\text { Privatization }\end{array}$ & Jan Hanousek and Zdenek Tima & Oct. 1997 \\
\hline $\begin{array}{l}\text { No. 74: Determinants of Performance of Manufacturing Firms in Seven } \\
\text { European Transition Economies }\end{array}$ & $\begin{array}{l}\text { Stijn Claessens, Simeon Djankov, } \\
\text { and Gerhard Pohl }\end{array}$ & Feb. 1997 \\
\hline $\begin{array}{l}\text { No. } 73 \text { Published in: Economics of Transition, "The Restructuring of } \\
\text { Large Firms in Slovak Republic." Vol. 6, No. 1, May 1998, pp. 67-85 }\end{array}$ & $\begin{array}{l}\text { Simeon Djankov and Gerhard } \\
\text { Pohl }\end{array}$ & May 1998 \\
\hline $\begin{array}{l}\text { No. 72: Law, Relationships, and Private Enforcement: Transactional } \\
\text { Strategies of Russian Enterprises }\end{array}$ & $\begin{array}{l}\text { Kathryn Hendley, Peter Murrell, } \\
\text { and Randi Ryterman }\end{array}$ & Nov. 1998 \\
\hline $\begin{array}{l}\text { No. 71: Giving Credit Where Credit Is Due: The Changing Role of } \\
\text { Rural Financial Institutions in China }\end{array}$ & $\begin{array}{l}\text { Albert Park, Loren Brandt, and } \\
\text { John Giles }\end{array}$ & Mar. 1997 \\
\hline $\begin{array}{l}\text { No. 70: Privatization Versus Competition: Changing Enterprise } \\
\text { Behavior in Russia }\end{array}$ & John S. Earle and Saul Estrin & $\begin{array}{l}\text { Spring } \\
1997 \\
\end{array}$ \\
\hline $\begin{array}{l}\text { No. 69: Russian Managers under Storm: Explicit Reality and Implicit } \\
\text { Leadership Theories (A Pilot Exploration) }\end{array}$ & Igor Gurkov & Oct. 1998 \\
\hline $\begin{array}{l}\text { No. 68: The Political Economy of Central-Local Relations in China: } \\
\text { Inflation and Investment Controls During the Reform Era }\end{array}$ & Yasheng Huang & $\begin{array}{l}\text { Spring } \\
1997\end{array}$ \\
\hline $\begin{array}{l}\text { No. 67: Between Two Coordination Failures: Automotive Industrial } \\
\text { Policy in China with a Comparison to Korea }\end{array}$ & Yasheng Huang & $\begin{array}{l}\text { Spring } \\
1997\end{array}$ \\
\hline $\begin{array}{l}\text { No. } 66 \text { Published in: Post-Soviet Geography and Economics, "Red } \\
\text { Executives in Russia's Transition Economy." Vol. 27, No. 10, Nov. } \\
\text { 1996, pp. 633-651. }\end{array}$ & Susan J. Linz & Jan. 1997 \\
\hline $\begin{array}{l}\text { No. } 65 \text { Published in: Industrial and Corporate Change, "On the } \\
\text { Sequencing of Privatization in Transition Economies." Vol. 7, No. 1, } \\
1998 .\end{array}$ & $\begin{array}{l}\text { Gautam Ahuja and Sumit K. } \\
\text { Majumdar }\end{array}$ & Apr. 1997 \\
\hline $\begin{array}{l}\text { No. 64: Published in: Journal of Law and Economics, "Foreign } \\
\text { Ownership and Profitability: Property Rights, Control and the } \\
\text { Performance of Firms in Indian Industry" } 42(1) \text {, Apr. 1999, pp. 209-38 }\end{array}$ & $\begin{array}{l}\text { Pradeep K. Chhibber and Sumit } \\
\text { K. Majumdar }\end{array}$ & Apr. 1997 \\
\hline
\end{tabular}




\begin{tabular}{|c|c|c|}
\hline No. 63: How Taxing Is Corruption on International Investors? & Shang-Jin Wei & Feb. 1997 \\
\hline $\begin{array}{l}\text { No. 62: What Can We Learn from the Experience of Transitional } \\
\text { Economies with Labour Market Policies? }\end{array}$ & Tito Boeri & 1997 \\
\hline $\begin{array}{l}\text { No. 61: Published in: Accounting Organizations and Society, } \\
\text { "Economic Transition, Strategy and the Evolution of Management } \\
\text { Accounting Practices: The Case of India" 24(5,6), Jul/Aug 1999, pp. } \\
\text { 379-412. }\end{array}$ & $\begin{array}{l}\text { Shannon W. Anderson and } \\
\text { William N. Lanen }\end{array}$ & Apr. 1997 \\
\hline $\begin{array}{l}\text { No. 60a: Enterprise Investment During the Transition: Evidence from } \\
\text { Czech Panel Data }\end{array}$ & Lubomír Lizal and Jan Svejnar & Dec. 1997 \\
\hline $\begin{array}{l}\text { No. 59: Published in: Journal of Law, Economics, and Organization, } \\
\text { "Institutional Environment, Community Government, and Corporate } \\
\text { Governance: Understanding China's Township-Village Enterprises." } \\
\text { 14(1), Apr. 1998, pages 1-23 }\end{array}$ & Jiahua Che and Yingyi Qian & Apr. 1997 \\
\hline No. 58: From the Grabbing Hand to the Helping Hand & Jiahua Che & June 2000 \\
\hline $\begin{array}{l}\text { No. 57: Published in: Brookings Papers on Economic Activity, "The } \\
\text { Unofficial Economy in Transition." 1: } 1998 .\end{array}$ & $\begin{array}{l}\text { Simon Johnson, Daniel } \\
\text { Kaufmann, and Andrei Schleifer }\end{array}$ & June 1997 \\
\hline No. 56: Taxes and Government Incentives: Eastern Europe vs. China & Roger H. Gordon and David D. Li & Apr. 1997 \\
\hline No. 55: Corruption and Reform & Susanto Basu and David Li & June 1996 \\
\hline $\begin{array}{l}\text { No. 54: Decentralization and the Macroeconomic Consequences of } \\
\text { Commitment to State-Owned Firms }\end{array}$ & Loren Brandt and Xiaodong Zhu & June 1997 \\
\hline $\begin{array}{l}\text { No. 53: Published in: The International Journal of Industrial } \\
\text { Organization, "Competitive Shocks and Industrial Structure: The Case } \\
\text { of Polish Manufacturing." Aug., 1999. . }\end{array}$ & $\begin{array}{l}\text { Pankaj Ghemawat and Robert E. } \\
\text { Kennedy }\end{array}$ & May 1997 \\
\hline $\begin{array}{l}\text { No. 52: Published in: The Quarterly Journal of Economics, "Insecure } \\
\text { Property Rights and Government Ownership of Firms." May, } 1998 .\end{array}$ & Jiahua Che and Yingyi Qian & May 1997 \\
\hline No. 51: Incentives, Scale Economies, and Organizational Form & $\begin{array}{l}\text { Eric Maskin, Yingyi Qian, and } \\
\text { Chenggang Xu }\end{array}$ & May 1997 \\
\hline $\begin{array}{l}\text { No. 50: Published in: Post-Soviet-Affairs, "End of the Tunnel? The } \\
\text { Effects of Financial Stabilization in Russia" Apr.-June 1997, pages 105- } \\
33\end{array}$ & $\begin{array}{l}\text { Barry W. Ickes, Peter Murrell, } \\
\text { and Randi Ryterman }\end{array}$ & Mar. 1997 \\
\hline $\begin{array}{l}\text { No. 49: The Evolution of Bank Credit Quality in Transition: Theory and } \\
\text { Evidence from Romania }\end{array}$ & $\begin{array}{l}\text { Enrico C. Perotti and Octavian } \\
\text { Carare }\end{array}$ & Oct. 1996 \\
\hline $\begin{array}{l}\text { No. 48: Where Do the Leaders Trade? Information Revelation and } \\
\text { Interactions Between the Segments of Czech Capital Markets }\end{array}$ & $\begin{array}{l}\text { Jan Hanousek and Libor } \\
\text { Nemecek }\end{array}$ & May 1997 \\
\hline $\begin{array}{l}\text { No. 47: Firms' Heterogeneity in Transition: Evidence from a Polish } \\
\text { Panel Data Set }\end{array}$ & $\begin{array}{l}\text { Irena Grosfeld and Jean-François } \\
\text { Nivet }\end{array}$ & May 1997 \\
\hline No. 46: Strategic Creditor Passivity, Regulation, and Bank Bailouts & et Mitchell & May 1997 \\
\hline $\begin{array}{l}\text { No. 45a: Published in: Journal of Public Economics, "Tax Rights in } \\
\text { Transition Economies: A Tragedy of the Commons." } 76,2000 \text {, pp. 369- } \\
397\end{array}$ & Daniel M. Berkowitz and Wei Li & Sept. 1997 \\
\hline $\begin{array}{l}\text { No. 44a: The Information Content of Stock Markets: Why do Emerging } \\
\text { Markets have Synchronous Stock Price Movements? (forthcoming in } \\
\text { the Journal of Financial Economics). }\end{array}$ & $\begin{array}{l}\text { Randall Morck, Bernard Yeung, } \\
\text { and Wayne Yu }\end{array}$ & Feb. 1999 \\
\hline $\begin{array}{l}\text { No. 43: Agency in Project Screening and Termination Decisions: Why } \\
\text { Is Good Money Thrown After Bad? }\end{array}$ & Chong-en Bai and Yijiang Wang & May 1997 \\
\hline $\begin{array}{l}\text { No. 42: Published in: Economics of Transition, "Channels of } \\
\text { Redistribution: Inequality and Poverty in the Russian Transition." Vol. } 7 \\
\text { (2) } 1999 .\end{array}$ & $\begin{array}{l}\text { Simon Commander, Andrei } \\
\text { Tolstopiatenko, and Ruslan } \\
\text { Yemtsov }\end{array}$ & May 1997 \\
\hline $\begin{array}{l}\text { No. 41: Published in: Economics of Transition, "Labour Market } \\
\text { Characteristics and Profitability: Econometric Analysis of Hungarian } \\
\text { Exporting Firms, 1986-1995" 6(1), May 1998, pages 145-62 }\end{array}$ & László Halpern and Gabor Korosi & May 1997 \\
\hline $\begin{array}{l}\text { No. 40: Published in: the Harvard Law Review, "The Tragedy of the } \\
\text { Anticommons: Property in the Transition from Marx to Markets." Jan. } \\
\text { 1998. }\end{array}$ & Michael Heller & Feb. 1997 \\
\hline No. 39: Privatization and Managerial Efficiency & $\begin{array}{l}\text { Olivier Debande and Guido } \\
\text { Friebel }\end{array}$ & May 1997 \\
\hline
\end{tabular}




\begin{tabular}{|c|c|c|}
\hline $\begin{array}{l}\text { No. } 38 \text { Published in: The Quarterly Journal of Economics, } \\
\text { "Disorganization." Vol. 112, No. 4, Nov. 1997, pp. 1091-1126. }\end{array}$ & $\begin{array}{l}\text { Olivier Blanchard and Michael } \\
\text { Kremer }\end{array}$ & Jan. 1997 \\
\hline $\begin{array}{l}\text { No. 37: Published in: Economics of Transition, "Transition and the } \\
\text { Output Fall." } 7(1), 1999 \text {, pages 1-28. }\end{array}$ & $\begin{array}{l}\text { Gérard Roland and Thierry } \\
\text { Verdier }\end{array}$ & Mar. 1997 \\
\hline $\begin{array}{l}\text { No. 36: Restructuring an Industry During Transition: A Two-Period } \\
\text { Model }\end{array}$ & Richard Ericson & Sept. 1996 \\
\hline No. 34: The East-West Joint Venture: BC Torsion Case Study & $\begin{array}{l}\text { Sonia Ferencikova and Vern } \\
\text { Terpstra }\end{array}$ & Dec. 1998 \\
\hline $\begin{array}{l}\text { No. } 33 \text { Published in: Journal of Comparative Economics, "Quantifying } \\
\text { Price Liberalization in Russia." Vol. 26, No. 4, Dec. 1998, pp. 735-737. }\end{array}$ & $\begin{array}{l}\text { Daniel Berkowitz, David DeJong, } \\
\text { and Steven Husted }\end{array}$ & Dec. 1998 \\
\hline No. 32: What Can North Korea Learn from China's Market Reforms? & John McMillan & Sept. 1996 \\
\hline $\begin{array}{l}\text { No. 31: Published in: China-Economic-Review, "Towards a Model of } \\
\text { China as a Partially Reformed Developing Economy Under a } \\
\text { Semifederalist Government." 9(1), Spring 1998, pages 1-23. }\end{array}$ & Yijiang Wang and Chun Chang & Mar. 1997 \\
\hline $\begin{array}{l}\text { No. 30: Convergence in Output in Transition Economies: Central and } \\
\text { Eastern Europe, } 1970-1995\end{array}$ & Saul Estrin and Giovanni Urga & Feb. 1997 \\
\hline $\begin{array}{l}\text { No. 29: Published in: Economics of Transition, "Altered Band and } \\
\text { Exchange Volatility." Volume 6, no. 1, 1998, 173-181. }\end{array}$ & Evzen Kocenda & Mar. 1997 \\
\hline $\begin{array}{l}\text { No. 28: Published in: Quarterly Journal of Economics, "Public Versus } \\
\text { Private Ownership of Firms: Evidence from Rural China." Volume 113, } \\
\text { no. 3, Aug. 1998, 773-808. }\end{array}$ & Hehui Jin and Yingyi Qian & Jan. 1997 \\
\hline $\begin{array}{l}\text { No. 27: East-West Joint Ventures in a Transitional Economy: The Case } \\
\text { of Slovakia }\end{array}$ & Sonia Ferencikova & Mar. 1997 \\
\hline $\begin{array}{l}\text { No. 26: Published in Economic Analysis "Behavior of a Slovenian Firm } \\
\text { in Transition" Vol. 1, no. 1, 1998, 57-73. }\end{array}$ & Janez Prasnikar & Feb. 1997 \\
\hline $\begin{array}{l}\text { No. 25: Cultural Encounters and Claims to Expertise in Postcommunist } \\
\text { Capitalism }\end{array}$ & Michael D. Kennedy & Feb. 1997 \\
\hline $\begin{array}{l}\text { No. 24: ZVU a.s.: Investment Funds on the Board of Directors of an } \\
\text { Engineering Giant }\end{array}$ & Tory Wolff & Aug. 1995 \\
\hline $\begin{array}{l}\text { No. 23: The Role of Investment Funds in the Czech Republic (joint } \\
\text { publication with Czech Management Center) }\end{array}$ & Dusan Triska & June 1996 \\
\hline $\begin{array}{l}\text { No. 22: Czech Investment Fund Industry: Development and Behaviour } \\
\text { (joint publication with Czech Management Center) }\end{array}$ & Richard Podpiera & May 1996 \\
\hline $\begin{array}{l}\text { No. 21: Restructuring of Czech Firms: An Example of Gama, a.s. (joint } \\
\text { publication with Czech Management Center) }\end{array}$ & Antonin Bulin & June 1996 \\
\hline $\begin{array}{l}\text { No. 20: YSE Funds: A Story of Czech Investment Funds (joint } \\
\text { publication with Czech Management Center) }\end{array}$ & Michal Otradovec & Nov. 1995 \\
\hline $\begin{array}{l}\text { No. 19: První Investicni a.s., The First Investment Corporation (joint } \\
\text { publication with Czech Management Center) }\end{array}$ & Jaroslav Jirasek & Aug. 1995 \\
\hline $\begin{array}{l}\text { No. 18: PPF a.s., The First Private Investment Fund (joint publication } \\
\text { with Czech Management Center) }\end{array}$ & Michal Otradovec & Nov. 1995 \\
\hline $\begin{array}{l}\text { No. } 17 \text { Published in: Post-Soviet Geography and Economics, "Russia's } \\
\text { Managers in Transition: Pilferers or Paladins?" 37(7) (Sept. 1996), pp. } \\
\text { 397-426. }\end{array}$ & Susan J. Linz and Gary Krueger & Nov. 1996 \\
\hline $\begin{array}{l}\text { No. 16: Banks in Transition-Investment Opportunities in Central } \\
\text { Europe and Russia, Edited Transcript from } 31 \text { May } 1996 \text { Conference in } \\
\text { New York City }\end{array}$ & $\begin{array}{l}\text { With commentary and edited by } \\
\text { Anna Meyendorff }\end{array}$ & Jan. 1997 \\
\hline $\begin{array}{l}\text { No. 15: Marketing in Transitional Economies: Edited Transcript \& } \\
\text { Papers from } 1 \text { Apr. } 1996 \text { Conference in Ann Arbor, Michigan }\end{array}$ & $\begin{array}{l}\text { Compiled by The Davidson } \\
\text { Institute }\end{array}$ & Dec. 1996 \\
\hline $\begin{array}{l}\text { No. 14: Pensions in the Former Soviet Bloc: Problems and Solutions. } \\
\text { Published by Council on Foreign Relations. "The Coming Global } \\
\text { Pension Crisis" New York, } 1997\end{array}$ & Jan Svejnar & Nov. 1996 \\
\hline $\begin{array}{l}\text { No. 13: Enterprise Restructuring and Performance in the Transition. } \\
\text { Forthcoming in Financial Systems in Transition: The Design of } \\
\text { Financial Systems in Central Europe eds. Anna Meyendorff and Anjan } \\
\text { Thakor. }\end{array}$ & $\begin{array}{l}\text { Lubomir Lizal, Miroslav Singer, } \\
\text { and Jan Svejnar }\end{array}$ & Dec. 1996 \\
\hline
\end{tabular}


Davidson Institute Working Papers are available at: www.wdi.bus.umich.edu

\begin{tabular}{|c|c|c|c|}
\hline \multicolumn{2}{|c|}{$\begin{array}{l}\text { No. } 12 \text { Published in: Journal of International Marketing, "Executive } \\
\text { Insights: Marketing Issues and Challenges in Transitional Economies." } \\
\text { Vol. 5, No. 4, 1997, pp. 95-114. Also published in: Marketing Issues in } \\
\text { Transitional Economies ed. Rajeev Batra. }\end{array}$} & Rajeev Batra & Apr. 1997 \\
\hline \multicolumn{2}{|c|}{$\begin{array}{l}\text { No. 11: Worker Trust and System Vulnerability in the Transition from } \\
\text { Socialism to Capitalism }\end{array}$} & Andrew Schotter & Aug. 1996 \\
\hline \multicolumn{2}{|c|}{$\begin{array}{l}\text { No. } 10 \text { Published in: Comparative Economic Studies, "Russian Firms in } \\
\text { Transition: Champions, Challengers, and Chaff." Vol. 39, No.2, } \\
\text { Summer 1997, pp. 1-36. }\end{array}$} & Susan J. Linz & July 1996 \\
\hline \multicolumn{2}{|c|}{$\begin{array}{l}\text { No. 9: Corporate Debt Crisis and Bankruptcy Law During the } \\
\text { Transition: The Case of China }\end{array}$} & David D. Li and Shan Li & Dec. 1995 \\
\hline \multicolumn{2}{|c|}{$\begin{array}{l}\text { No. } 8 \text { Published in: Journal of Comparative Economics, "A Theory of } \\
\text { Ambiguous Property Rights in Transition Economies: The Case of the } \\
\text { Chinese Non-State Sector." Vol. 23, No. 1, Aug. 1996, pp. 1-19. }\end{array}$} & David D. Li & June 1996 \\
\hline \multicolumn{2}{|c|}{$\begin{array}{l}\text { No. 7: The Foreign Economic Contract Law of China: Cases and } \\
\text { Analysis }\end{array}$} & lai Li & June 1993 \\
\hline \multicolumn{2}{|c|}{$\begin{array}{l}\text { No. 3: Bank Privatization in Hungary and the Magyar Kulkereskedelmi } \\
\text { Bank Transaction }\end{array}$} & $\begin{array}{l}\text { Roger Kormendi and Karen } \\
\text { Schnatterly }\end{array}$ & May 1996 \\
\hline $\begin{array}{l}\text { Replacing No. 1: Journal of Comparative Economics } \\
\text { Symposium on "Bank Privatization in Central Europe and } \\
\text { Russia." Vol. 25, No. 1, Aug. } 1997 .\end{array}$ & \multicolumn{2}{|c|}{$\begin{array}{l}\text { "Bank Privatization in Transitional } \\
\text { Economies," Roger Kormendi and Edward } \\
\text { Snyder. }\end{array}$} & Aug. 1997 \\
\hline $\begin{array}{l}\text { Replacing No. 2: Journal of Comparative Economics } \\
\text { Symposium on "Bank Privatization in Central Europe and } \\
\text { Russia." Vol. 25, No. 1, Aug. } 1997 .\end{array}$ & \multicolumn{2}{|c|}{$\begin{array}{l}\text { "Transactional Structures of Bank } \\
\text { Privatizations in Central Europe and } \\
\text { Russia," Anna Meyendorff and Edward A. } \\
\text { Snyder. }\end{array}$} & Aug. 1997 \\
\hline $\begin{array}{l}\text { Replacing No. 4: Journal of Comparative Economics } \\
\text { Symposium on "Bank Privatization in Central Europe and } \\
\text { Russia." Vol. 25, No. 1, Aug. } 1997 .\end{array}$ & \multicolumn{2}{|c|}{$\begin{array}{l}\text { "Bank Privatization in Poland: The Case of } \\
\text { Bank Slaski," Jeffery Abarbaness and John } \\
\text { Bonin. }\end{array}$} & Aug. 1997 \\
\hline $\begin{array}{l}\text { Replacing No. 5: Journal of Comparative Economics } \\
\text { Symposium on "Bank Privatization in Central Europe and } \\
\text { Russia." Vol. 25, No. 1, Aug. } 1997 .\end{array}$ & \multicolumn{2}{|c|}{$\begin{array}{l}\text { "Bank Privatization in Post-Communist } \\
\text { Russia: The Case of Zhilsotsbank," Jeffery } \\
\text { Abarbanell and Anna Meyendorff }\end{array}$} & Aug. 1997 \\
\hline $\begin{array}{l}\text { Replacing No. 6: Journal of Comparative Economics } \\
\text { Symposium on "Bank Privatization in Central Europe and } \\
\text { Russia." Vol. 25, No. 1, Aug. } 1997 .\end{array}$ & \multicolumn{2}{|c|}{$\begin{array}{l}\text { "The Czech Republic's Commercial Bank: } \\
\text { Komercni Banka," Edward A. Snyder and } \\
\text { Roger C. Kormendi. }\end{array}$} & Aug. 1997 \\
\hline
\end{tabular}

